\title{
Insights on Bimetallic Micellar Nanocatalysis for Buchwald-Hartwig Aminations
}

Tharique N. Ansari, ${ }^{\dagger}, \ddagger$ Armand Taussat, ${ }^{\dagger, \ddagger}$ Adam H. Clark, ${ }^{\perp}$ Maarten Nachtegaal,,$\perp$ Scott Plummer," Fabrice Gallou, ${ }^{\#}$ Sachin Handa*

'Department of Chemistry

University of Louisville

Louisville, KY 40292

*sachin.handa@1ouisville.edu

Paul Scherrer Institute

Forschungsstrasse 111

5232 Villigen, Switzerland

'Novartis Institutes for Biomedical Research

250 Massachusetts Ave, Cambridge, MA 02139

"Novartis Pharma AG, Basel

4056, Switzerland

\section{Supplementary Material}

\section{Contents}

1. General experimental details

2. Reaction optimization

3. Synthesis and isolation of nanocatalyst

4. Catalytic activity - isolated nanocatalyst versus in-situ formed

5. Optimized procedure for catalytic couplings

6. Substrate scope

7. Gram-scale reaction

8. Recyclability at gram scale

9. E factor and recycle study

10. Effect of additional $\mathrm{Cu}\left(\mathrm{CH}_{3} \mathrm{CN}\right)_{4} \mathrm{PF}_{6}$ addition on recyclability

11. Role of charcoal

12. Kinetic study on recyclability of catalyst

13. Sonogashira couplings using nanocatalyst

14. Suzuki-Miyaura coupling with nanocatalyst

15. ICP-MS analysis

16. DLS experiments for particle size determination

17. Detailed analysis of nanocatalyst

18. Analytical Data

19. References

S20. NMR Spectra
Page

$\mathrm{S} 2$

S3-S8

S9

S10-S11

S11-S12

$\mathrm{S} 13$

S14

S15-S16

S17-S18

S19-20

S21-S26

S27-S30

S31

S32

S33

S33-S34

S35-S43

S44-S52

S53-S54

S55-85 


\section{GENERAL EXPERIMENTAL DETAILS}

All manipulations were carried out under argon atmosphere unless otherwise noted. TLC plates (UV 254 indicator, glass backed, thickness $200 \mathrm{~mm}$ ) and silica gel (standard grade, $230-400$ mesh) were purchased from Merck. Diethyl ether, THF, ethyl acetate, methylene chloride, and hexanes were purchased from Fisher Scientific. Methyl tert-butyl ether was purchased from Sigma-Aldrich. Et $3 \mathrm{~N}$ and $i$ - $\mathrm{Pr}_{2} \mathrm{NEt}$ were distilled and stored under argon. $\mathrm{KOH}, \mathrm{K}_{3} \mathrm{PO}_{4}$, and $\mathrm{K}_{2} \mathrm{CO}_{3}$ were purchased from Fisher Scientific and used as such without any further purification. $\mathrm{MeMgBr}$ and $\mathrm{Fe}_{2} \mathrm{O}_{3}$ was purchased from Sigma Aldrich. Ligands were either purchased from Strem Chemicals, Sigma-Aldrich or gifted by Novartis Pharmaceuticals. Palladium(II) acetate and tetrakis(acetonitrile)copper(I) hexafluorophosphate was purchased from Strem Chemicals and used as such without further purification. Pure NMR solvents were purchased from Cambridge Isotopes Laboratories. (Hetero)aryl amines and (hetero)aryl bromides were purchased from SigmaAldrich, Combi-Block, Alfa Aesar, and Oakwood chemicals. The coupling reactions were performed in $4 \mathrm{~mL}$ close-cap microwave vials under argon atmosphere. The charcoal was purchased from Acros with a brand name NORIT ${ }^{\circledR}$. Microwave vials were purchased from VWR International and Biotage. Reaction vials were also recycled and reused. Bulk aqueous solution of surfactant PS-750-M was prepared in HPLC grade water and thoroughly purged with argon before use. Melting points were determined using a MEL-TEMP II melting point apparatus with samples in Kimble Kimex 51 capillaries (1.5-1.8 x $90 \mathrm{~mm})$. Unless otherwise mentioned, all NMR spectra were recorded at $25^{\circ} \mathrm{C}$ on Varian Unity INOVA (400, 500 and $700 \mathrm{MHz}$ ) spectrometers. Reported chemical shifts are referenced to residual solvent peaks. HRMS spectra were obtained on a Thermo Electron MAT 95XP mass spectrometer using either electron ionization (EI) or chemical ionization (CI). 


\section{REACTION OPTIMIZATION}

Table S1. Optimal Pd/M ratio

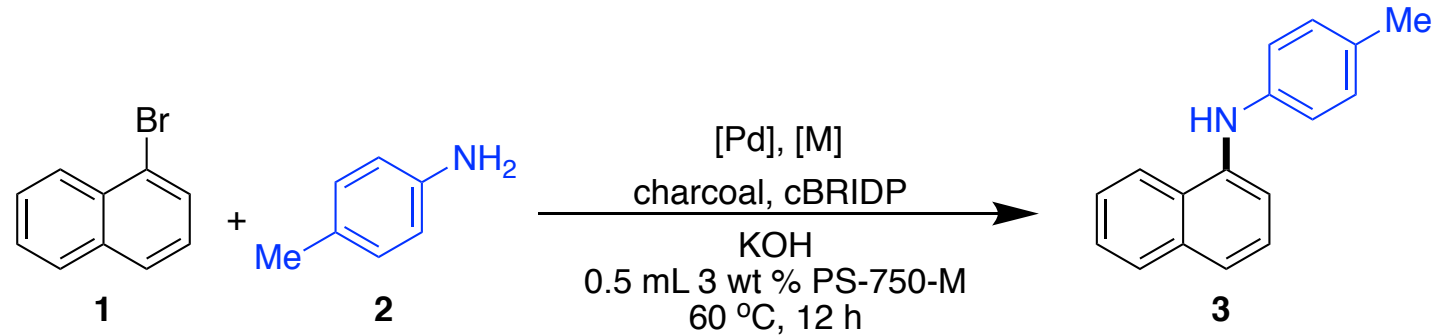

\begin{tabular}{|c|c|c|c|c|}
\hline entry & {$[\mathrm{Pd}]$} & {$[\mathrm{M}]$} & $\begin{array}{l}\text { cBRIDP } \\
(\mathrm{mol} \%)\end{array}$ & $3(\%)^{a}$ \\
\hline 1 & $1 \mathrm{~mol} \% \operatorname{Pd}(\mathrm{OAc})_{2}$ & - & 1 & 62 \\
\hline 2 & $0.5 \mathrm{~mol} \% \mathrm{Pd}(\mathrm{OAc})_{2}$ & - & 0.5 & 16 \\
\hline 3 & $1 \mathrm{~mol} \% \operatorname{Pd}(\mathrm{OAc})_{2}$ & $2 \mathrm{~mol} \% \mathrm{Cu}\left(\mathrm{CH}_{3} \mathrm{CN}\right)_{4} \mathrm{PF}_{6}$ & 3 & 85 \\
\hline 4 & $0.5 \mathrm{~mol} \% \mathrm{Pd}(\mathrm{OAc})_{2}$ & $2 \mathrm{~mol} \% \mathrm{Cu}\left(\mathrm{CH}_{3} \mathrm{CN}\right)_{4} \mathrm{PF}_{6}$ & 2.5 & 61 \\
\hline 5 & - & $2 \mathrm{~mol} \% \mathrm{Cu}\left(\mathrm{CH}_{3} \mathrm{CN}\right)_{4} \mathrm{PF}_{6}$ & 2 & 0 \\
\hline 6 & $1 \mathrm{~mol} \% \operatorname{Pd}(\mathrm{OAc})_{2}$ & $1 \mathrm{~mol} \% \mathrm{Cu}\left(\mathrm{CH}_{3} \mathrm{CN}\right)_{4} \mathrm{PF}_{6}$ & 2 & 72 \\
\hline 7 & - & $2 \mathrm{~mol} \% \mathrm{Ni}(\mathrm{OAc})_{2}$ & 2 & 0 \\
\hline 8 & $1 \mathrm{~mol} \% \mathrm{Pd}(\mathrm{OAc})_{2}$ & $2 \mathrm{~mol} \% \mathrm{Ni}(\mathrm{OAc})_{2}$ & 3 & traces \\
\hline 9 & - & $2 \mathrm{~mol} \% \mathrm{CoCl}_{2} \cdot 6 \mathrm{H}_{2} \mathrm{O}^{b}$ & - & 0 \\
\hline 10 & $1 \mathrm{~mol} \%[(\pi \text {-cinnamyl }) \mathrm{PdCl}]_{2}$ & - & 1 & 26 \\
\hline 11 & $1 \mathrm{~mol} \%[(\pi \text {-cinnamyl }) \mathrm{PdCl}]_{2}{ }^{c}$ & - & 1 & traces \\
\hline 12 & $1 \mathrm{~mol} \%[(\pi \text {-crotyl }) \mathrm{PdCl}]_{2}$ & - & 1 & traces \\
\hline 13 & $1 \mathrm{~mol} \%[(\pi \text {-crotyl }) \mathrm{PdCl}]_{2}^{c}$ & - & 1 & 29 \\
\hline 14 & $1 \mathrm{~mol} \% \mathrm{Pd}(\mathrm{OAc})_{2}{ }^{c}$ & $5 \mathrm{~mol} \% \mathrm{FeCl}_{3}$ & 1 & 8 \\
\hline 15 & $1 \mathrm{~mol} \% \mathrm{Pd}(\mathrm{OAc})_{2}{ }^{d}$ & - & 1 & 71 \\
\hline
\end{tabular}

Conditions. 1 ( $0.25 \mathrm{mmol}), 2(0.3 \mathrm{mmol})$, [Pd], [M], charcoal (ca. 1.0 equiv. based on $12 \mathrm{amu})$, cBRIDP, KOH (1 mmol), 3 wt \% PS-750-M (0.5 mL), $60{ }^{\circ} \mathrm{C}, 12 \mathrm{~h}$.

${ }^{a}$ Yields based on GCMS.

$\left.{ }^{b}(2 \mathrm{~mol} \%) 1 E, 1^{\prime} E\right)$-1,1'-(pyridine-2,6-diyl)bis( $N$-(2,6-diisopropylphenyl)ethan-1-imine) was used as ligand. ${ }^{c} \mathrm{MeMgBr}(2 \mathrm{~mol} \%)$ was used to generate nanoparticles (no charcoal support was used).

${ }^{d} \mathrm{KOH}(0.75 \mathrm{mmol})$ was used instead of $1.0 \mathrm{mmol}$. 
Table S2. Choice of ligand

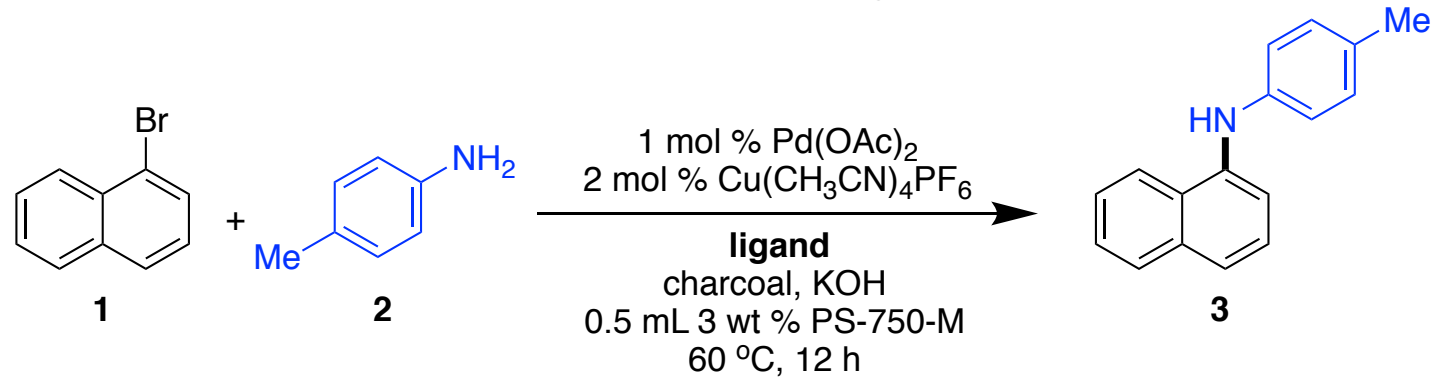

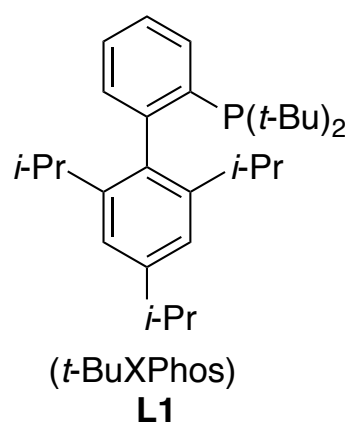

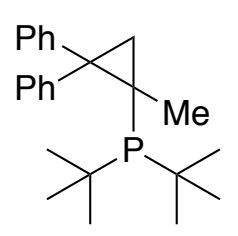

(cBRIDP)

L2<smiles>COc1cccc(OC)c1-c1ccccc1P(C)(F)(F)F</smiles>

(SPhos)

L3<smiles>CCCCc1ccccc1-c1c(C(C)C)cc(C(C)C)cc1C(C)C</smiles>

(XPhos)

\begin{tabular}{ccc}
\hline entry & ligand & $\mathbf{3}(\%)^{a}$ \\
\hline 1 & L1 & 20 \\
2 & L2 & 85 \\
3 & L3 & 12 \\
4 & L4 & $<7$
\end{tabular}

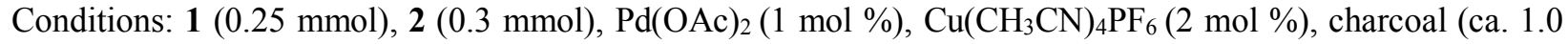
equiv. based on $12 \mathrm{amu}$ ), ligand ( $3 \mathrm{~mol} \%), \mathrm{KOH}(1 \mathrm{mmol}), 3 \mathrm{wt} \%$ PS-750-M $(0.5 \mathrm{~mL}), 60{ }^{\circ} \mathrm{C}, 12 \mathrm{~h} .{ }^{a}$ Yields based on GCMS. 
Table S3. Solid support other than carbon<smiles>Brc1cccc2ccccc12</smiles>

1<smiles>Cc1ccc(N)cc1</smiles>

2

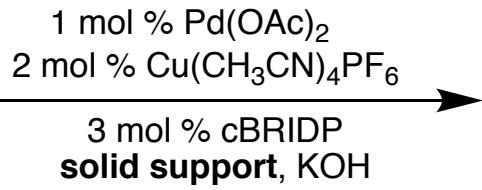

$0.5 \mathrm{~mL} 3$ wt \% PS-750-M $60^{\circ} \mathrm{C}, 12 \mathrm{~h}$<smiles>Cc1ccc(Nc2cccc3ccccc23)cc1</smiles>

\begin{tabular}{ccc}
\hline entry & solid support (1.0 equiv) & $\mathbf{3}(\%)^{a}$ \\
\hline 1 & chitin & 59 \\
2 & $\mathrm{Fe}_{2} \mathrm{O}_{3}$ & 17 \\
3 & chitosan & 46 \\
3 & carbon & 85
\end{tabular}

Conditions: 1 (0.25 mmol), $2(0.3 \mathrm{mmol}), \mathrm{Pd}(\mathrm{OAc})_{2}(1 \mathrm{~mol} \%), \mathrm{Cu}\left(\mathrm{CH}_{3} \mathrm{CN}\right)_{4} \mathrm{PF}_{6}(2 \mathrm{~mol} \%)$, solid support, cBRIDP (3 mol \%), KOH (1 mmol), 3 wt \% PS-750-M $(0.5 \mathrm{~mL}), 60{ }^{\circ} \mathrm{C}, 12 \mathrm{~h} .{ }^{a}$ Yields based on GCMS.

Table S4. Nature of copper source

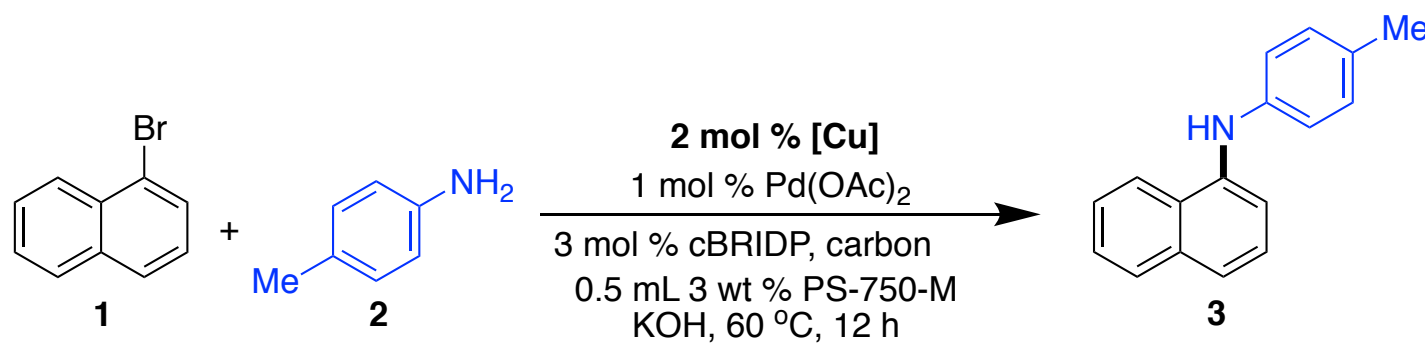

\begin{tabular}{ccc}
\hline entry & {$[\mathrm{Cu}](\mathrm{mol} \%)$} & $\mathbf{3}(\%)^{a}$ \\
\hline 1 & $\mathrm{CuI}$ & 77 \\
2 & $\mathrm{CuCl}$ & 47 \\
3 & $\mathrm{Cu}(\mathrm{OTf})_{2}$ & 19 \\
4 & $\mathbf{C u}(\mathbf{M e C N})_{\mathbf{4}} \mathbf{P F}_{\mathbf{6}}$ & 85
\end{tabular}

Conditions: 1 ( $0.25 \mathrm{mmol}), 2$ (0.3 mmol), $\mathrm{Pd}(\mathrm{OAc})_{2}(1 \mathrm{~mol} \%),[\mathrm{Cu}](2 \mathrm{~mol} \%)$, charcoal (ca. 1.0 equiv. based on $12 \mathrm{amu})$, cBRIDP (3 mol \%), KOH (1.0 mmol), $3 \mathrm{wt} \%$ PS-750-M $(0.5 \mathrm{~mL}), 12 \mathrm{~h} .{ }^{a}$ Yields based on GCMS. 
Table S5. Choice of base<smiles>Cc1ccc(N)cc1</smiles>
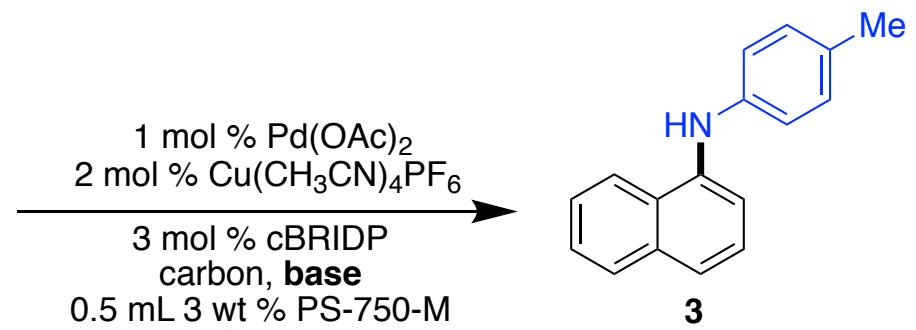
$60{ }^{\circ} \mathrm{C}, 12 \mathrm{~h}$

\begin{tabular}{ccc}
\hline entry & base (4.0 equiv.) & $\mathbf{3}(\%)^{a}$ \\
\hline 1 & $\mathrm{~K}_{2} \mathrm{CO}_{3}$ & 70 \\
2 & $\mathbf{K}_{\mathbf{3}} \mathbf{P O}_{4} \cdot \mathbf{H}_{2} \mathbf{O}$ & $\mathbf{8 0}$ \\
4 & $i-\mathrm{PrNEt}_{2}$ & 24 \\
5 & $\mathrm{Et}_{3} \mathrm{~N}$ & 40 \\
$\mathbf{6}$ & $\mathbf{K O H}$ & $\mathbf{8 5}$
\end{tabular}

Conditions: 1 (0.25 mmol), $2(0.3 \mathrm{mmol}), \mathrm{Pd}(\mathrm{OAc})_{2}(1 \mathrm{~mol} \%), \mathrm{Cu}\left(\mathrm{CH}_{3} \mathrm{CN}\right)_{4} \mathrm{PF}_{6}(2 \mathrm{~mol} \%)$, charcoal (ca. 1.0 equiv. based on $12 \mathrm{amu})$, cBRIDP ( $3 \mathrm{~mol} \%$ ), base $(1.0 \mathrm{mmol}), 3 \mathrm{wt} \% \mathrm{PS}-750-\mathrm{M}(0.5 \mathrm{~mL}), 60{ }^{\circ} \mathrm{C}, 12 \mathrm{~h} .{ }^{a}$ Yields based on GCMS.

Table S6. Optimal equivalents of base

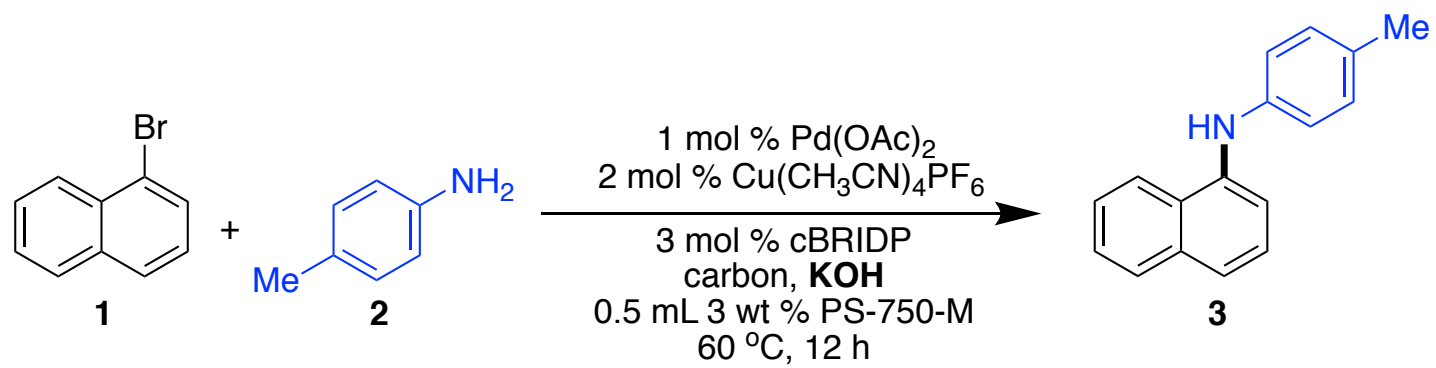

\begin{tabular}{ccc}
\hline entry & KOH (equiv.) & $\mathbf{3}(\%)^{a}$ \\
\hline 1 & 1.0 & 72 \\
2 & 2.0 & 80 \\
$\mathbf{3}$ & $\mathbf{3 . 0}$ & $\mathbf{9 5}$ \\
4 & 4.0 & 85 \\
\hline
\end{tabular}

Conditions: 1 (0.25 mmol), 2 (0.3 mmol), $\mathrm{Pd}(\mathrm{OAc})_{2}(1 \mathrm{~mol} \%), \mathrm{Cu}\left(\mathrm{CH}_{3} \mathrm{CN}\right)_{4} \mathrm{PF}_{6}(2 \mathrm{~mol} \%)$, charcoal (cal.0 equiv. based on $12 \mathrm{amu})$, cBRIDP (3 mol \%), KOH, $3 \mathrm{wt} \%$ PS-750-M $(0.5 \mathrm{~mL}), 12 \mathrm{~h} .{ }^{a}$ Yields based on GCMS. 
Table S7. Reaction solvent

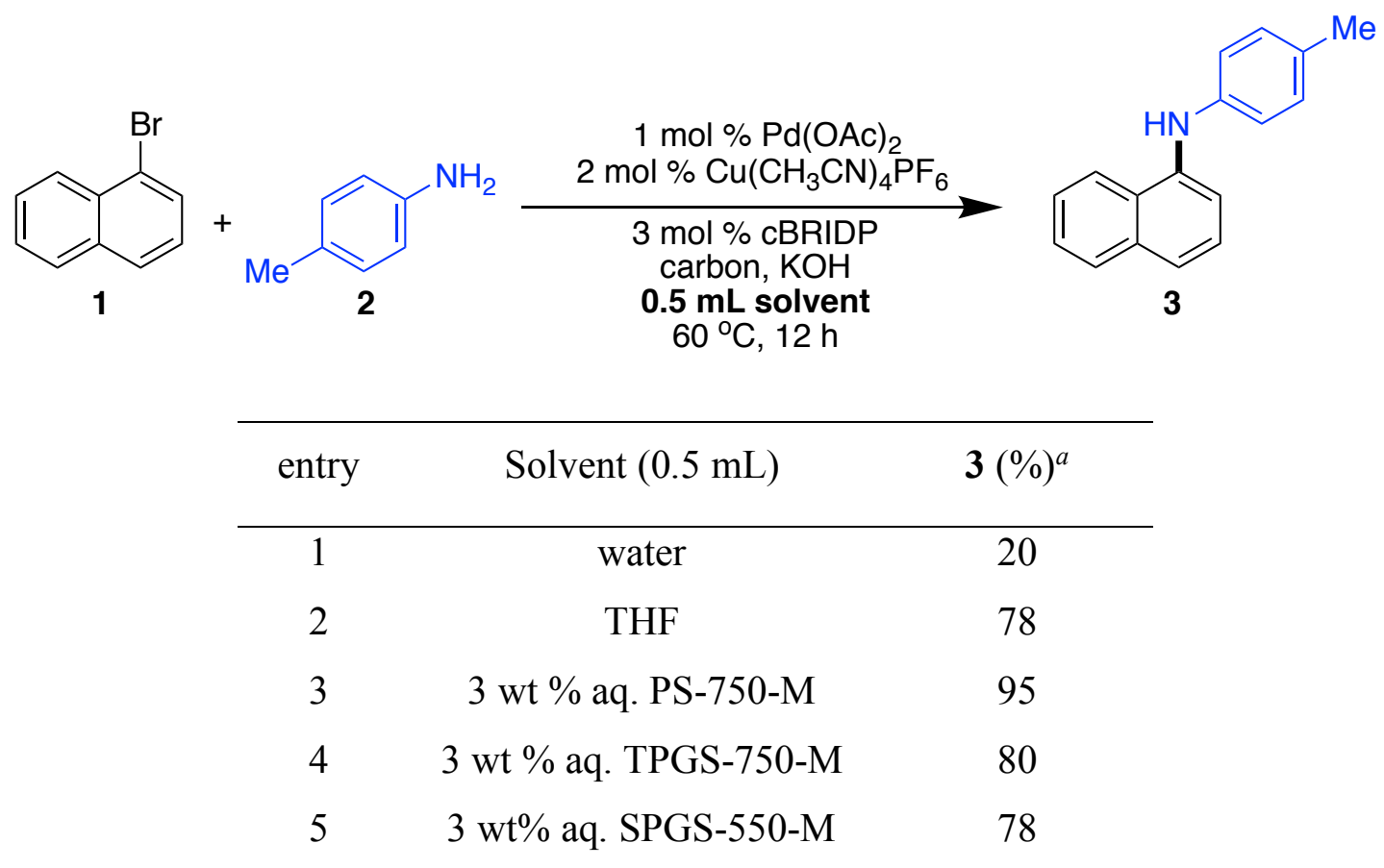

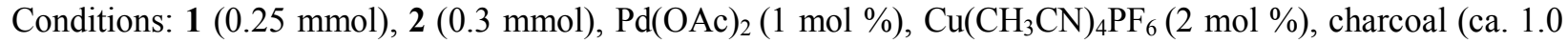
equiv. based on $12 \mathrm{amu}$ ), cBRIDP ( $3 \mathrm{~mol} \%$ ), $\mathrm{KOH}$ (3.0 equiv.), $0.5 \mathrm{~mL}$ solvent, $60{ }^{\circ} \mathrm{C}, 12 \mathrm{~h} .{ }^{a}$ Yields based on GCMS.

Table S8. Optimal reaction temperature

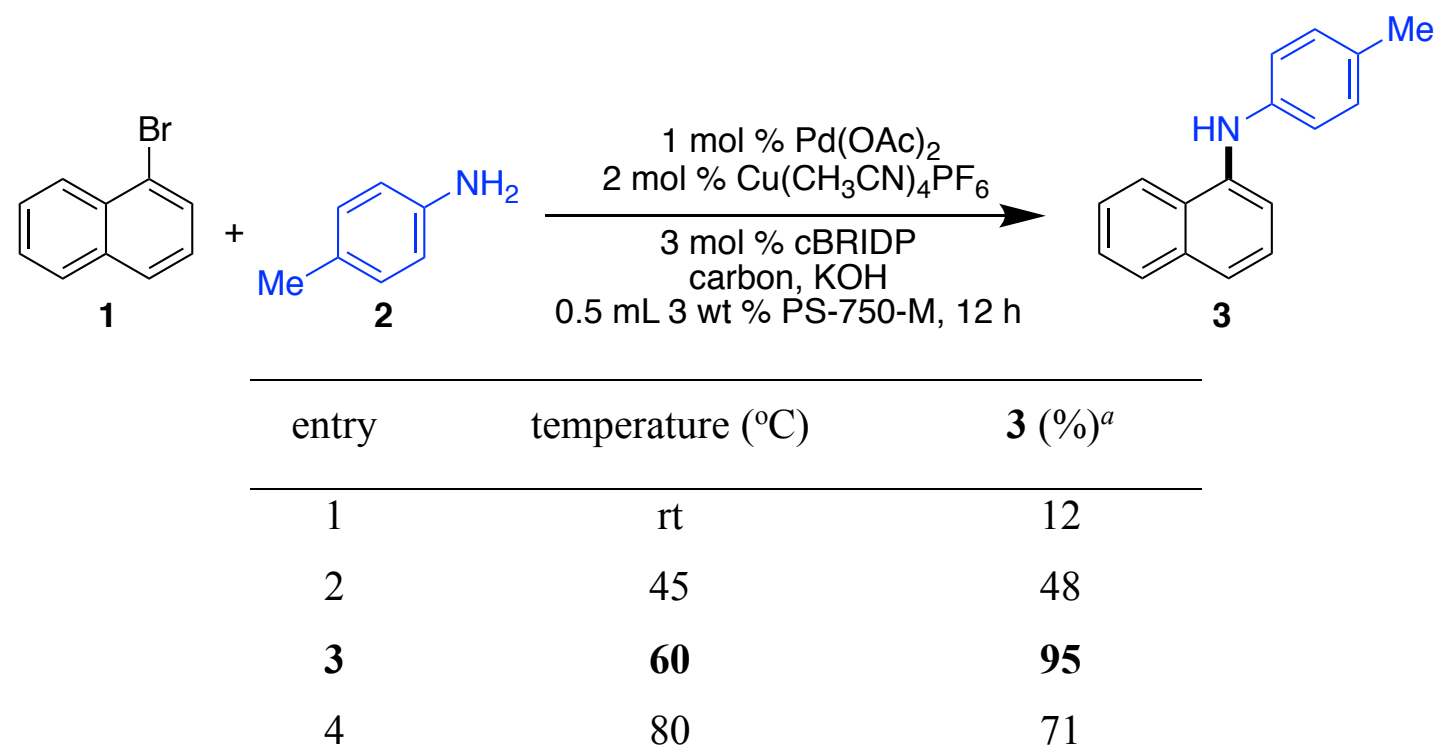

Conditions: 1 (0.25 mmol), $2(0.3 \mathrm{mmol}), \mathrm{Pd}(\mathrm{OAc})_{2}(1 \mathrm{~mol} \%), \mathrm{Cu}\left(\mathrm{CH}_{3} \mathrm{CN}\right)_{4} \mathrm{PF}_{6}(2 \mathrm{~mol} \%)$, charcoal (ca. 1.0 equiv. based on $12 \mathrm{amu}$ ), cBRIDP ( $3 \mathrm{~mol} \%$ ), $\mathrm{KOH}$ (3.0 equiv.), $3 \mathrm{wt} \% \mathrm{PS}-750-\mathrm{M}$ in $\mathrm{H}_{2} \mathrm{O}(0.5 \mathrm{~mL}), 12 \mathrm{~h} .{ }^{a}$ Yields based on GCMS. 
Table S9. Optimal stoichiometry of coupling partners

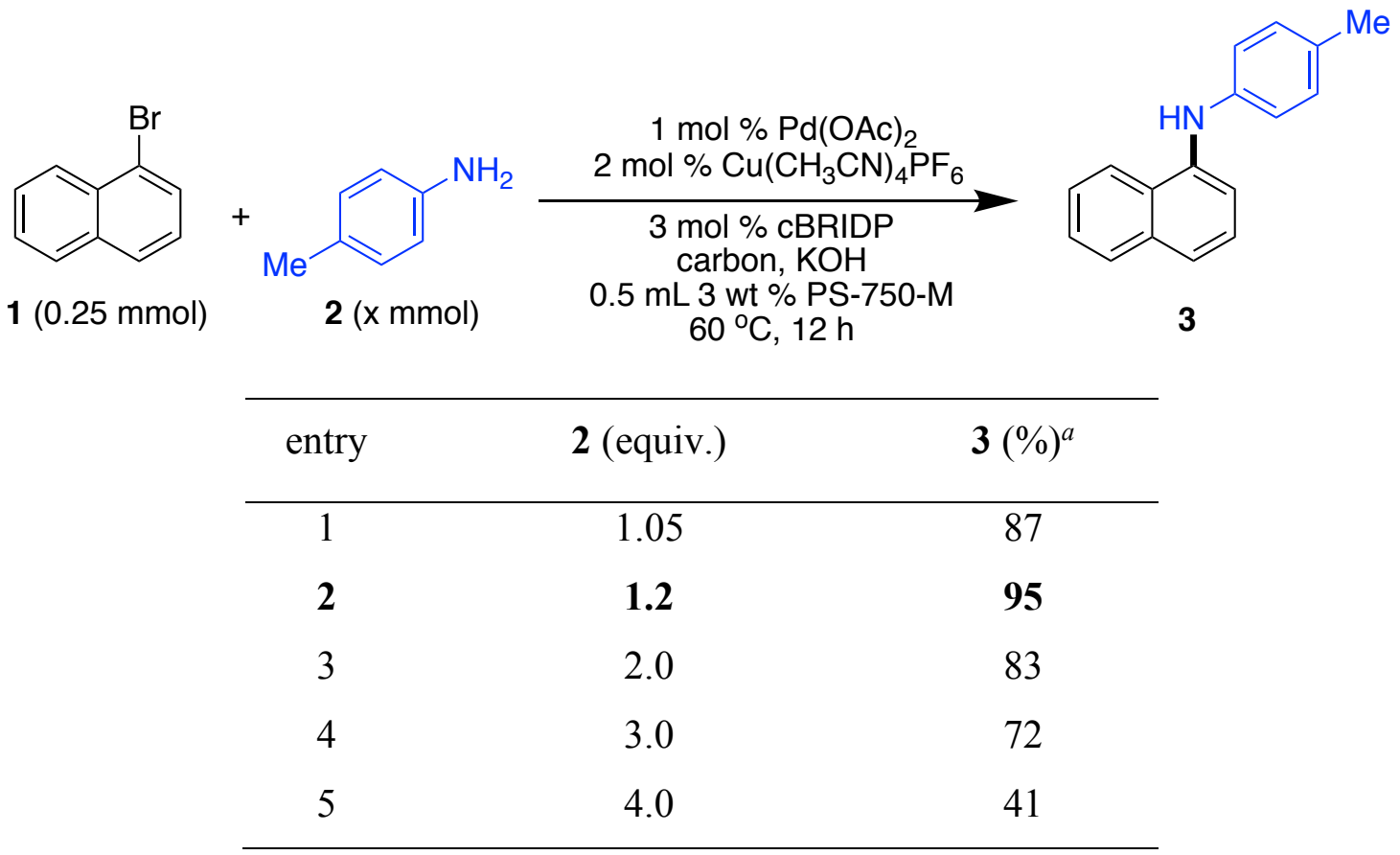

Conditions: 1 (0.25 mmol), 2, $\mathrm{Pd}(\mathrm{OAc})_{2}(1 \mathrm{~mol} \%), \mathrm{Cu}\left(\mathrm{CH}_{3} \mathrm{CN}\right)_{4} \mathrm{PF}_{6}(2 \mathrm{~mol} \%)$, charcoal (ca. 1.0 equiv. based on $12 \mathrm{amu}$ ), cBRIDP (3 mol \%), $\mathrm{KOH}$ (3.0 equiv.), $0.5 \mathrm{~mL} 3 \mathrm{wt} \%$ aq. PS-750-M, $60{ }^{\circ} \mathrm{C}, 12 \mathrm{~h} .{ }^{a}$ Yields based on GCMS.

Table S10. Optimal global concentration

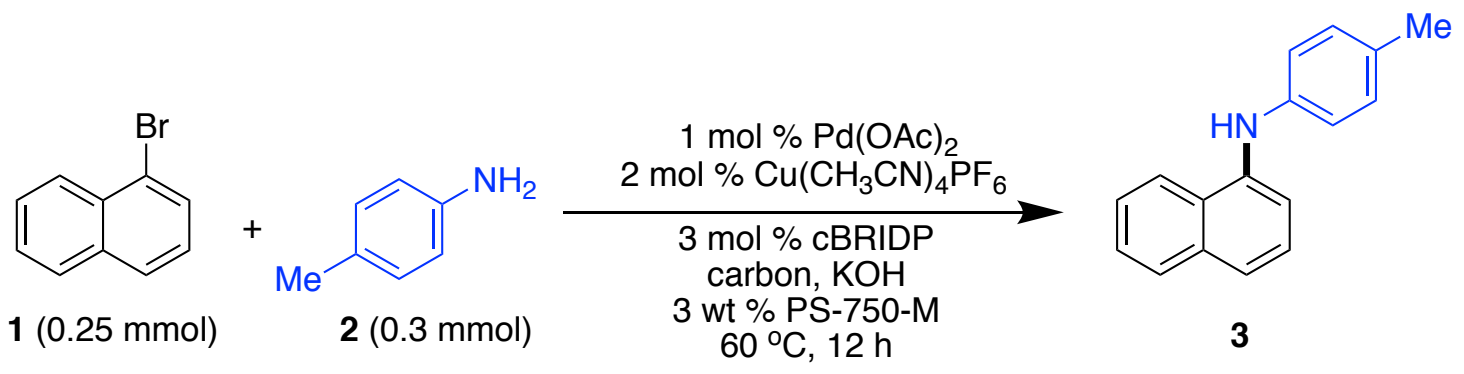

\begin{tabular}{ccc}
\hline entry & conc. (M) & $\mathbf{3}(\%)^{a}$ \\
\hline 1 & 0.25 & 79 \\
$\mathbf{2}$ & $\mathbf{0 . 5}$ & $\mathbf{9 5}$ \\
3 & 1.0 & 81 \\
4 & 2.0 & 30
\end{tabular}

Conditions: 1 (0.25 mmol), $2(0.3 \mathrm{mmol}), \mathrm{Pd}(\mathrm{OAc})_{2}(1 \mathrm{~mol} \%), \mathrm{Cu}\left(\mathrm{CH}_{3} \mathrm{CN}\right)_{4} \mathrm{PF}_{6}(2 \mathrm{~mol} \%)$, charcoal (ca. 1.0 equiv. based on $12 \mathrm{amu}$ ), cBRIDP (3 mol \%), $\mathrm{KOH}$ (3.0 equiv.), $3 \mathrm{wt} \%$ aq. PS-750-M, $60{ }^{\circ} \mathrm{C}, 12 \mathrm{~h} .{ }^{a}$ Yields based on GCMS. 


\section{SYNTHESIS AND ISOLATION OF NANOCATALYST}

In an oven-dried $4 \mathrm{~mL}$ reaction vial containing a PTFE-coated stir bar, $\mathrm{Pd}(\mathrm{OAc})_{2}(6.7 \mathrm{mg}, 0.028$ mmol), tetrakis(acetonitrile)copper(I) hexafluorophosphate (22 mg, $0.057 \mathrm{mmol}$ ), and cBRIDP (31.7 mg, $0.084 \mathrm{mmol}$ ) were added. Reaction vial was closed with a rubber septum. Reaction vials was evacuated and then back-filled with argon. This process of evacuation and backfilling with argon was repeated for three times. $1.0 \mathrm{~mL}$ dry THF was added to the reaction mixture. Reaction mixture was gently heated with a heat gun $\left(\mathrm{ca} .70^{\circ} \mathrm{C}\right)$ for a minute. During heating, reaction mixture color was changed from yellow to reddish-brown. Using pre-heated oil bath, reaction mixture was further heated at $60{ }^{\circ} \mathrm{C}$ for $15 \mathrm{~min}$. Reaction mixture was allowed to cool to rt. Reaction vial was opened under argon atmosphere and activated charcoal $(30 \mathrm{mg})$ was added to it. Reaction vial was closed with a rubber septum, and the mixture was further stirred for 30 minutes at $60{ }^{\circ} \mathrm{C}$. Finally, volatiles were removed under reduced pressure and resulting solid material was dried under vacuum for an hour. The resulting solid (yield $92 \mathrm{mg}$ ) was used as such as a catalyst. The catalyst is stable under air and can be stored under ambient conditions for months.

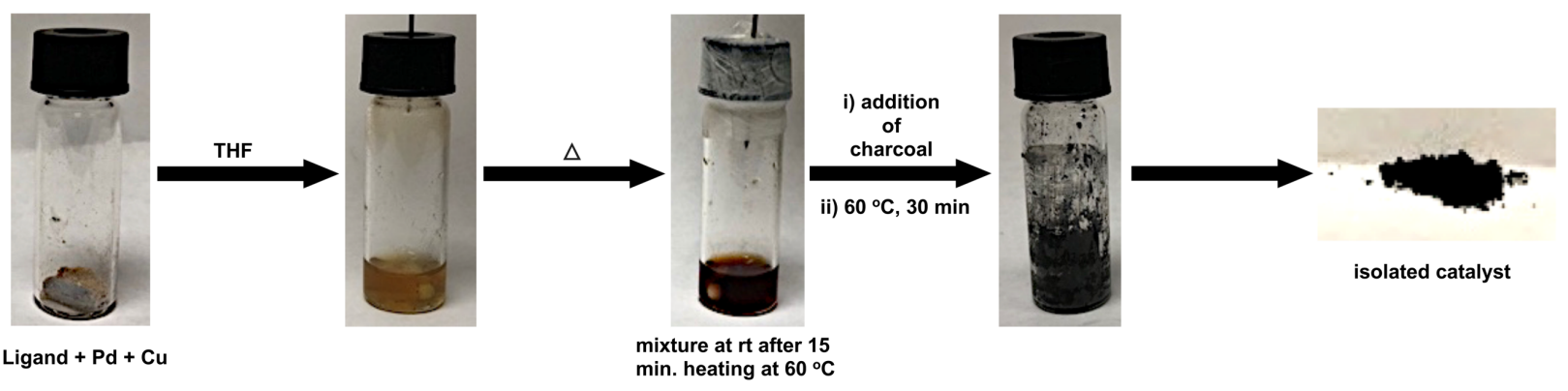

Figure S1. Nanocatalyst preparation and isolation. 


\section{CATALYTIC ACTIVITY - ISOLATED NANOCATALYST VERSUS IN-SITU FORMED}

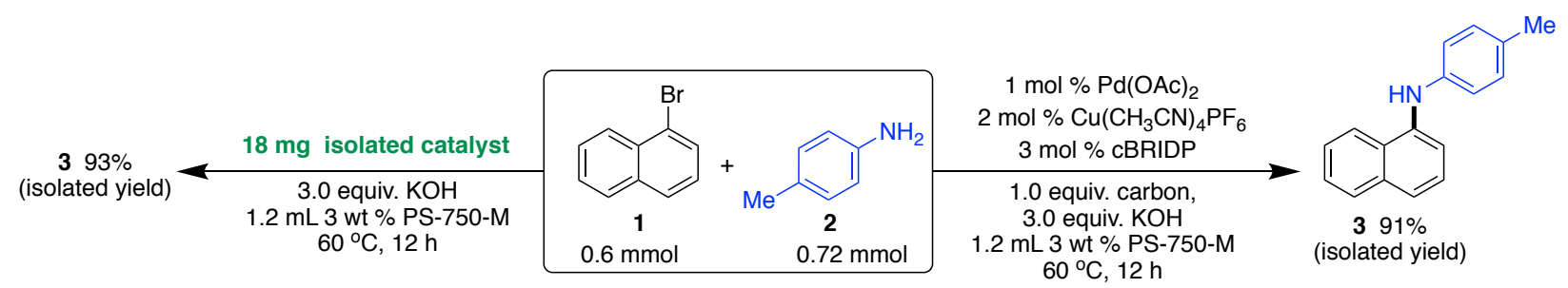

Scheme S1. Catalytic activity - isolated nanocatalyst v/s in-situ generated catalyst.

4.1. Amination with the isolated catalyst. 1-Boromonaphthalene (124 mg, $0.6 \mathrm{mmol}), p$ toluidine (77 mg, $0.72 \mathrm{mmol})$, nanocatalyst $(18 \mathrm{mg})$, and $\mathrm{KOH}(100 \mathrm{mg}, 1.8 \mathrm{mmol})$ were added into a $4 \mathrm{~mL}$ oven-dried reaction vial containing PTFE-coated stirrer bar (Scheme S1 - left side). Reaction vial was evacuated and back-filled with argon for three times. $1.2 \mathrm{~mL}$ aqueous solution of PS-750-M was added to the reaction mixture. Reaction mixture was purged with argon for 2 minutes and then stirred for $12 \mathrm{~h}$ at $60^{\circ} \mathrm{C}$.

After complete consumption of starting material as monitored by TLC, reaction mixture was allowed to cool to rt. MTBE $(0.5 \mathrm{~mL})$ was added to the reaction mixture and mixture was stirred for a minute at rt. Stirring was stopped and organic layer was allowed to separate. Organic layer was withdrawn with the aid of syringe needle. This extraction process was repeated for an additional time. Combined organic layers were dried over anhydrous sodium sulfate. Volatiles were removed under reduce pressure to obtain crude product. Crude product was purified by flash chromatography over silica gel using EtOAc/hexanes as eluent $\left(\mathrm{R}_{f}=0.4,9: 1\right.$ hexanes/EtOAc). Pure product was obtained as viscous oil, yield $130 \mathrm{mg}$ (93\%). Similar result is obtained up on using 6-month-old catalyst.

\subsection{Amination with in-situ formed catalyst. $\mathrm{Pd}(\mathrm{OAc})_{2} \quad(1.34 \mathrm{mg}, 0.006 \mathrm{mmol})$,} tetrakis(acetonitrile)copper(I) hexafluorophosphate (4.4 mg, $0.012 \mathrm{mmol})$, and cBRIDP (6.4 mg, $0.018 \mathrm{mmol}$ ) were transferred into a $4 \mathrm{~mL}$ oven-dried reaction vial containing PTFE-coated stirrer bar (Scheme S1 - right side). Reaction vessel was evacuated and back-filled with argon for three times. $0.3 \mathrm{~mL}$ dry THF was added to the reaction vial and mixture was gently heated with a heat gun to obtain dark red color mixture. Reaction mixture was heated at $60{ }^{\circ} \mathrm{C}$ for additional $15 \mathrm{~min}$. Reaction mixture was allowed to cool to rt. Charcoal powder was added to the reaction mixture, which was then heated at $60{ }^{\circ} \mathrm{C}$ for $15 \mathrm{~min}$. Reaction mixture was allowed to cool to rt. THF was 
removed under vacuum. To the resulting mixture, 1-boromonaphthalene (124 mg, $0.6 \mathrm{mmol}), p$ toluidine (77 mg, $0.72 \mathrm{mmol})$, and $\mathrm{KOH}(100 \mathrm{mg}, 1.8 \mathrm{mmol})$ were sequentially added under positive argon pressure. $1.2 \mathrm{~mL}$ aqueous solution of PS-750-M was then added to the reaction mixture. Reaction mixture was purged with argon for $2 \mathrm{~min}$. Reaction mixture was stirred at $60{ }^{\circ} \mathrm{C}$ for $12 \mathrm{~h}$.

After complete consumption of starting material as monitored by TLC, reaction mixture was allowed to cool to rt. MTBE $(0.5 \mathrm{~mL})$ was added to the reaction mixture, and mixture was stirred for a minute at rt. Stirring was stopped and organic layer was allowed to separate. Organic layer was withdrawn with the aid of syringe needle. This extraction process was repeated for an additional time. Combined organic layer was dried over anhydrous sodium sulfate and volatiles were removed under reduce pressure to obtain crude product. Crude product was purified by flash chromatography over silica gel using EtOAc/hexanes as eluent $\left(\mathrm{R}_{f}=0.4,9: 1\right.$ hexanes/EtOAc). Pure product was obtained as viscous oil, yield $127 \mathrm{mg}(91 \%)$.

\section{OPTIMIZED PROCEDURE FOR CATALYTIC COUPLINGS}

5.1. With the isolated catalyst. Hetero/aryl bromide $(0.3 \mathrm{mmol})$, Aryl/alkyl amine $(0.36 \mathrm{mmol})$, charcoal immobilized nanocatalyst $(9.0 \mathrm{mg})$, and $\mathrm{KOH}(50.4 \mathrm{mg}, 0.9 \mathrm{mmol})$ were added into the $4 \mathrm{~mL}$ oven-dried reaction vial containing PTFE-coated stirrer-bar. Reaction vial was closed with a rubber septum. Reaction mixture was evacuated and back-filled with argon for three times. 0.6 $\mathrm{mL}$ aqueous solution of $3 \mathrm{wt} \%$ PS-750-M was added to the reaction mixture. Reaction mixture was purged with argon for $2 \mathrm{~min}$. Reaction vial was heated at $60{ }^{\circ} \mathrm{C}$.

After the complete consumption of starting material as monitored by TLC and GCMS, the mixture was cooled to room temperature. Septum was removed and $0.5 \mathrm{~mL}$ MTBE or EtOAc was added to the reaction mixture, which was then stirred for a minute at rt. Stirring was stopped and organic layer was allowed to separate from aqueous layer. Organic layer was removed with the help of pipette. This extraction process was repeated for additional time. Combined organic layer was dried over anhydrous sodium sulfate and volatiles were removed under reduced pressure to obtain crude product. Crude product was further purified by flash chromatography over silica gel using EtOAc and Hexanes as eluent. 
5.2. With in-situ formed catalyst. In a $4 \mathrm{~mL}$ oven-dried reaction vial equipped with PTFE coated magnetic stirrer bar, $\mathrm{Pd}(\mathrm{OAc})_{2}(0.003 \mathrm{mmol}, 100 \mu \mathrm{L}$ from a $0.03 \mathrm{M}$ stock solution in THF), tetrakis(acetonitrile)copper(I) hexafluorophosphate (2.2 $\mathrm{mg}, 0.006 \mathrm{mmol})$, and cBRIDP (3.2 $\mathrm{mg}$, $0.009 \mathrm{mmol}$ ) were added under inert atmosphere. Reaction vial was closed with a rubber septum. Reaction mixture was gently heated with a heat gun to obtain dark red color mixture. Reaction mixture was heated at $60{ }^{\circ} \mathrm{C}$ for additional $15 \mathrm{~min}$. Reaction mixture was allowed to cool to $\mathrm{rt}$. Under inert atmosphere, charcoal $(3.0 \mathrm{mg})$ powder was added to the reaction mixture. Reaction mixture was again heated at $60{ }^{\circ} \mathrm{C}$ for $15 \mathrm{~min}$ to generate active nanocatalyst. THF was evacuated from the catalyst at rt, Aryl(heteroaryl) bromide $(0.3 \mathrm{mmol})$, aryl(alkyl) amine $(0.36 \mathrm{mmol})$, and $\mathrm{KOH}(50.4 \mathrm{mg}, 0.9 \mathrm{mmol}$ ) were added to the reaction mixture. Reaction vessel was closed with a rubber septum. Reaction vessel was evacuated and backfilled with argon for three times. To this mixture, $0.6 \mathrm{~mL}$ aqueous solution of $3 \mathrm{wt} \%$ PS-750-M was added. Reaction mixture was purged with argon for $2 \mathrm{~min}$. Reaction mixture was heated at $60^{\circ} \mathrm{C}$.

After the complete consumption of starting material as monitored by TLC and GCMS, the mixture was cooled to room temperature. $0.5 \mathrm{~mL}$ MTBE or EtOAc was added to the reaction mixture and mixture was stirred for a minute at rt. Stirring was stopped and two layers were allowed to separate. Organic layer was withdrawn with the help of pipette. This extraction process was repeated for an additional time. Combined organic layers were dried over anhydrous sodium sulfate and volatiles were removed under reduced pressure to obtain crude product. Crude product was further purified by flash chromatography over silica gel using EtOAc/hexanes as eluent. 


\section{SUBSTRATE SCOPE}

Table S11. Substrate scope for the Buchwald-Hartwig amination

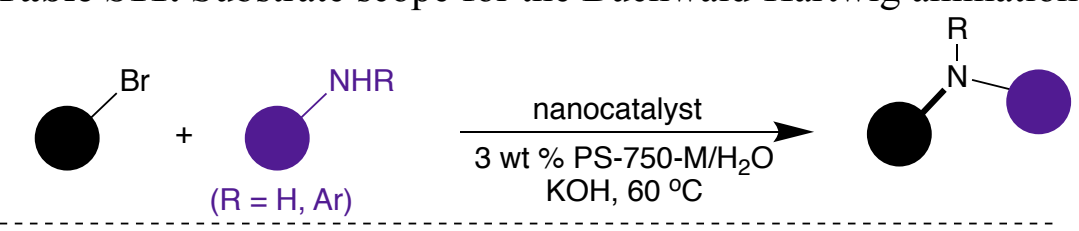

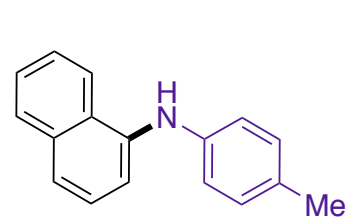

$393 \%(16 h)$<smiles>c1ccc2c(N3CCOCC3)cccc2c1</smiles>

$483 \%(18 h)$

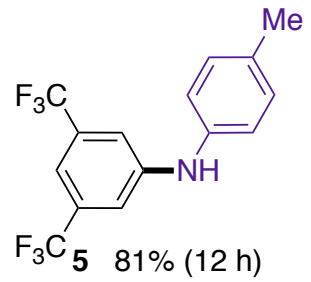<smiles>COc1ccc2c(ccn2-c2cc(C(F)(F)F)cc(C(F)(F)F)c2)c1</smiles><smiles>COc1ccc(-n2ccc3ccccc32)cc1</smiles><smiles>COc1ccc(Nc2ccccc2)cc1</smiles><smiles>[X]c1ccc(Nc2ccc(Cl)cc2)cc1</smiles><smiles>COc1ccc(Nc2ccc(C)cc2)cc1</smiles><smiles>COc1cccc(N2CCOCC2)n1</smiles><smiles>COc1cccc(Nc2ccc(C)cc2)n1</smiles><smiles>Cc1ccc(Nc2ncccn2)cc1</smiles><smiles>COc1ccc2c(c1)-c1cc(n1)-n-2-c1ccc(Cl)cc1</smiles><smiles>N#Cc1ccc(-n2ccc3ccccc32)cc1</smiles>

$1582 \%(14 \mathrm{~h})$<smiles>Cc1ccc(Nc2ccc3c(ccn3C(=O)OC(C)(C)C)c2)cc1</smiles>

$1663 \%(21 \mathrm{~h})$<smiles>FC(F)(F)c1cc(Nc2ccc3c(ccn3Cc3ccccc3)c2)cc(C(F)(F)F)c1</smiles><smiles>c1ccc2nc(-n3ccc4ccccc43)ccc2c1</smiles>

$1865 \%(36 \mathrm{~h})$<smiles>COc1cccc(-n2ccc3ccccc32)n1</smiles><smiles>Cc1ccc(Nc2ccc3ccccc3n2)cc1</smiles>

$2078 \%(20 \mathrm{~h})$<smiles>Cc1ccc(Nc2ccc3sccc3c2)cc1</smiles>

$1988 \%(23 \mathrm{~h})$<smiles>Cc1ccc(N2c3ccccc3Sc3ccccc32)cc1</smiles><smiles>Fc1cccc(N2CCN(Cc3cc(C(F)(F)F)cc(C(F)(F)F)c3)CC2)c1</smiles>

$2180 \%(41 \mathrm{~h})$<smiles>FC(F)(F)c1cc(N2c3ccccc3SC3=CC=[14CH][14CH]32)cc(C(F)(F)F)c1</smiles>

$2372 \%(35 \mathrm{~h})$

$2480 \%(27 \mathrm{~h})$

$2577 \%(36 \mathrm{~h})$

Conditions: $\mathrm{ArBr}(0.3 \mathrm{mmol})$, aryl amine $(0.36 \mathrm{mmol})$, nanocatalyst $(9 \mathrm{mg}, 1 \mathrm{~mol} \%$ based on $\mathrm{Pd}), \mathrm{KOH}(0.9 \mathrm{mmol}, 3.0$ equiv), $3 \mathrm{wt} \%$ PS-750-M in $\mathrm{H}_{2} \mathrm{O}(0.6 \mathrm{~mL}), 60^{\circ} \mathrm{C}$. All yields are isolated. 


\section{GRAM SCALE REACTION}

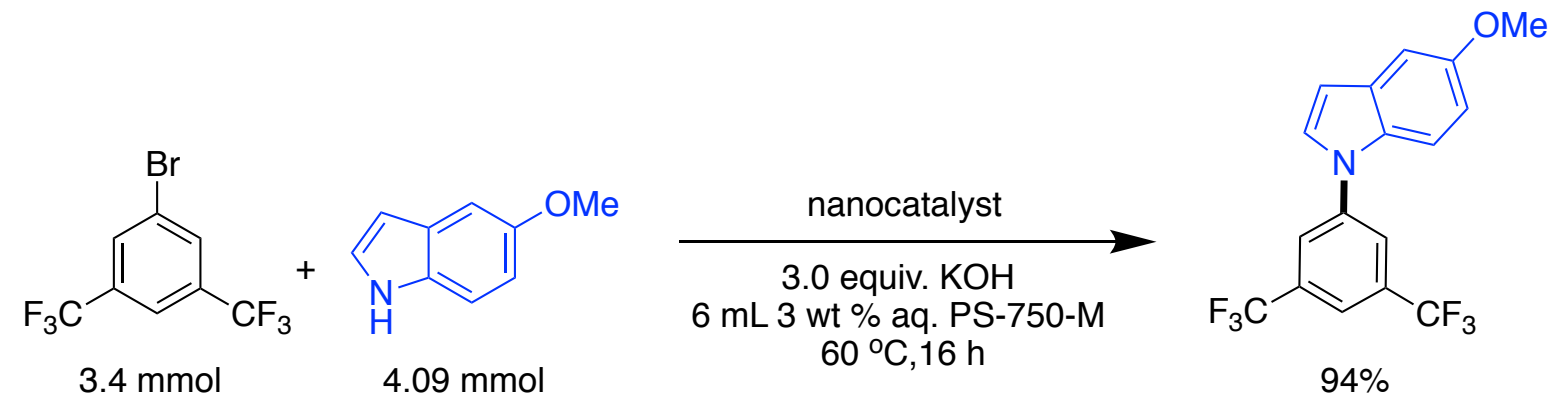

Scheme S2. Gram scale reaction.

5-Methoxy-1H-indole (0.6 g, $4.09 \mathrm{mmol})$, nanocatalyst (110 mg), and $\mathrm{KOH}(0.57 \mathrm{~g}, 10.2 \mathrm{mmol})$ were added into the $25 \mathrm{~mL}$ oven-dried reaction vial containing PTFE-coated stirrer bar. Reaction vial was evacuated and backfilled with argon for three times. 1-Bromo-3,5bis(trifluoromethyl)benzene $(0.58 \mathrm{~mL}, 3.4 \mathrm{mmol})$ and $6 \mathrm{~mL}$ aqueous solution of PS-750-M were added to the reaction vial. Reaction mixture was purged with argon for 5 minutes and then stirred at $60{ }^{\circ} \mathrm{C}$ for $16 \mathrm{~h}$ (Scheme S2). After complete consumption of starting material as monitored by TLC and GCMS, reaction flask was allowed to cool to rt. $3 \mathrm{~mL}$ of EtOAc was added to the reaction mixture without opening the septa. Reaction mixture was then stirred for 2 min at rt. Stirring was stopped and organic layers was allowed to separate out from an aqueous layer. Organic layer was taken out with the use of $3 \mathrm{~mL}$ syringe needle. Same extraction procedure was repeated for an additional time. Combined organic layers were dried over anhydrous sodium sulfate. Volatiles were removed under reduced pressure to obtain crude product. Crude product was purified by flash chromatography over silica gel using hexanes/ethyl acetate as eluent $\left(\mathrm{R}_{f} 0.4,4: 1\right.$ hexanes/ethyl acetate), yield $95 \%$ (1.16 g). 


\section{RECYCLABILITY AT GRAM SCALE}
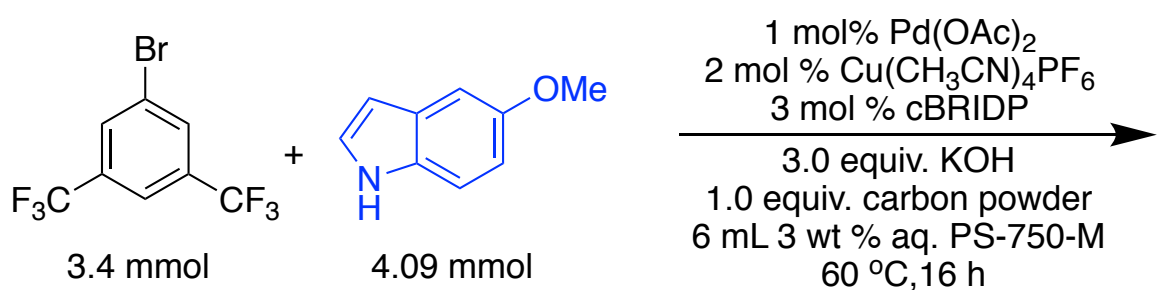

$60{ }^{\circ} \mathrm{C}, 16 \mathrm{~h}$

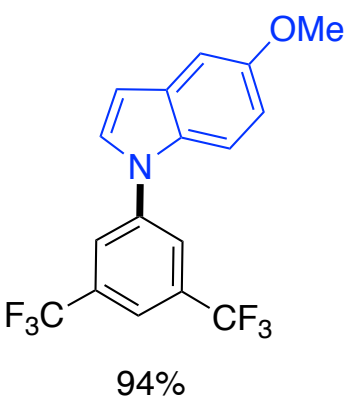

Scheme S3. Initial reaction: Recyclability of nanocatalyst at a gram scale reaction.

To a $25 \mathrm{~mL}$ oven-dried round-bottomed flask containing a PTFE-coated stir bar, $\mathrm{Pd}(\mathrm{OAc})_{2}(7.65$ $\mathrm{mg}, 1 \mathrm{~mol} \%$ ), tetrakis(acetonitrile)copper(I) hexafluorophosphate (25.4 $\mathrm{mg}, 2 \mathrm{~mol} \%$ ), and cBRIDP (36.0 mg, 3 mol\%) were added. Reaction flask was closed with a rubber septum and mixture was evacuated and back-filled with argon for three times. Via syringe, dry THF $(1.0 \mathrm{~mL})$ was added to the reaction mixture and gently heated with heat gun, which caused immediate color change of a reaction mixture from yellow to reddish-brown. Mixture was further heated at $60^{\circ} \mathrm{C}$ for $15 \mathrm{~min}$. Reaction mixture was allowed to cool to rt. The reaction vial was opened and activated charcoal (41 mg) was added to it. Reaction flask was closed with a rubber septum and mixture was stirred at $60^{\circ} \mathrm{C}$ for $15 \mathrm{~min}$. THF was evaporated under reduced pressure and $6 \mathrm{~mL}$ aqueous solution of $3 \mathrm{wt} \%$ PS-750-M was added to the mixture. Reaction mixture was stirred for $5 \mathrm{~min}$. Under argon atmosphere, 1-bromo-3,5-bis(trifluoromethyl)benzene (0.58 ml, $3.4 \mathrm{mmol})$, 5-methoxy-1Hindole $(0.6 \mathrm{~g}, 4.09 \mathrm{mmol})$, and $\mathrm{KOH}(0.57 \mathrm{~g}, 10.2 \mathrm{mmol})$ were sequentially added to reaction mixture. Reaction flask was closed with a rubber septum and mixture was purged with argon for $5 \mathrm{~min}$. Reaction mixture was stirred at $60^{\circ} \mathrm{C}$ for $16 \mathrm{~h}$ (Scheme $\mathrm{S} 3$ ).

After complete consumption of starting material as monitored by TLC and GCMS, reaction flask was allowed to cool to rt. $3 \mathrm{~mL}$ of MTBE was added to the reaction mixture without opening the septum. Reaction mixture was then stirred for $2 \mathrm{~min}$. Stirring was stopped and organic layers was allowed to separate out from an aqueous layer. Organic layer was taken out with the use of $3 \mathrm{~mL}$ syringe needle. Same extraction procedure was repeated for an additional time. Aqueous layer containing the catalyst was retained for a recycling test at gram scale reaction. Combined organic layers were dried over anhydrous sodium sulfate. Volatiles were removed under reduced pressure 
to obtain crude product. Crude product was purified by flash chromatography over silica gel using hexanes/ethyl acetate as eluent ( $\mathrm{R}_{f}$ 0.4, 4:1 hexanes/ethyl acetate), white solid, yield 94\% (1.14 g). To the remaining aqueous reaction medium containing the catalyst, $1 \mathrm{~mL} 3 \mathrm{wt} \%$ aqueous solution PS-750-M was added. Resulting solution was reused for another gram-scale reaction with different coupling partners as described below (Scheme S4).

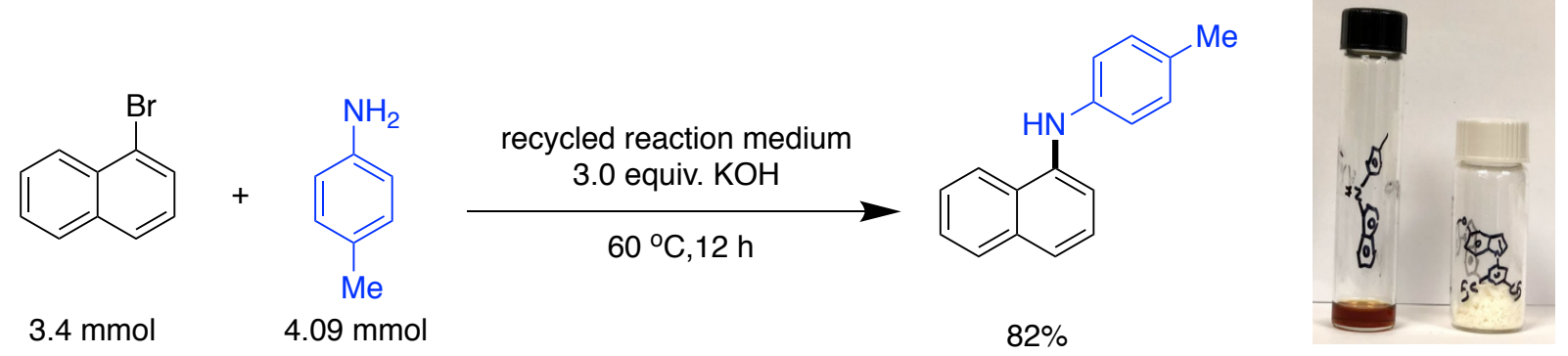

Scheme S4. Recyclability of nanocatalyst at a gram scale reaction.

An above aqueous mixture retaining the catalyst was purged with an argon for $10 \mathrm{~min}$. The solution was further charged with 1-bromonaphthalene $(0.47 \mathrm{~mL}, 3.4 \mathrm{mmol}), p$-toludine $(0.48 \mathrm{~g}, 4.09$ $\mathrm{mmol})$ and $\mathrm{KOH}(0.57 \mathrm{~g}, 10.2 \mathrm{mmol})$ under positive argon pressure. Reaction flask was closed with a rubber septum and mixture was allowed to stir at $60{ }^{\circ} \mathrm{C}$ for $12 \mathrm{~h}$. After complete consumption of starting material as monitored by TLC and GCMS, reaction flask was allowed to cool to rt. $3 \mathrm{~mL}$ of MTBE was added to the reaction mixture without opening the septa. Reaction mixture was then stirred for $2 \mathrm{~min}$. Stirring was stopped and organic layer was allowed to separate out from an aqueous layer. Organic layer was taken out with the use of $3 \mathrm{~mL}$ syringe needle. Same extraction procedure was repeated for an additional time. Combined organic layers were dried over anhydrous sodium sulfate. Volatiles were removed under reduced pressure to obtain crude product. Crude product was purified by flash chromatography over silica gel using hexanes/ethyl acetate as eluent $\left(\mathrm{R}_{f} 0.4\right.$, 9:1 hexanes:ethyl acetate), viscous oil, yield 82\% (650 mg). 


\section{E FACTOR AND RECYCLE STUDY}

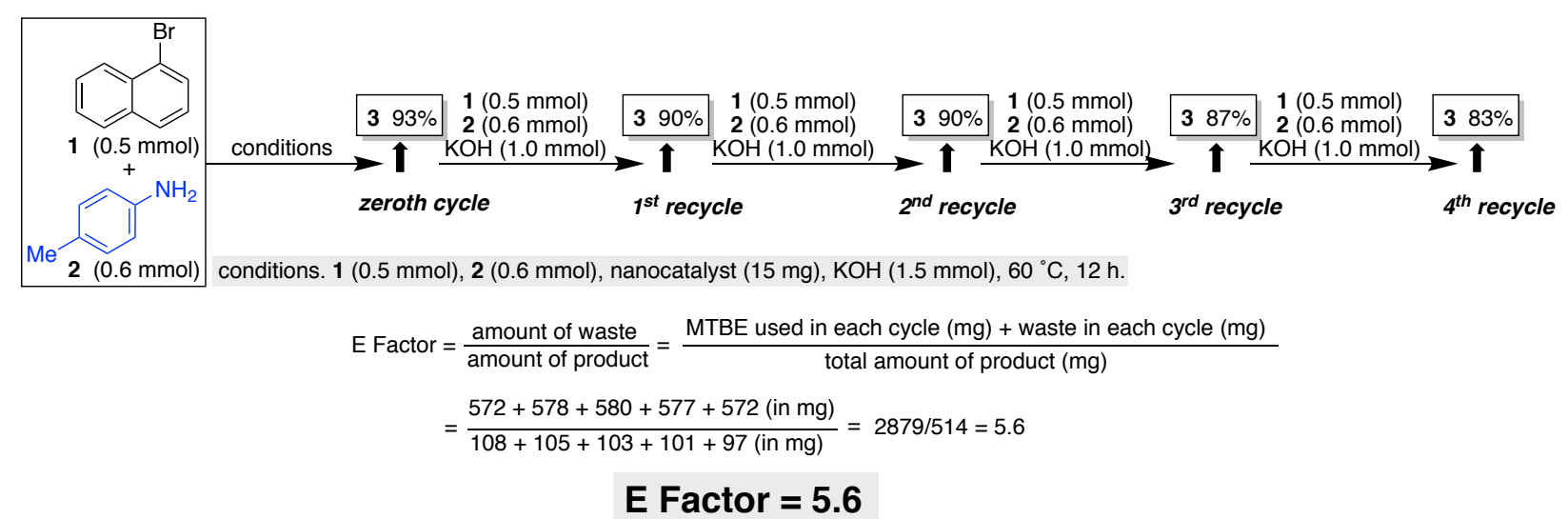

Scheme S5. Recycle study and E factor calculation.

Caution. (i) Argon purged MTBE must be used; (ii) after each cycle, the catalyst containing reaction medium must be purged with argon; (iii) for improved extraction, use warm MTBE.

Zeroth cycle: In a $4.0 \mathrm{~mL}$ flame-dried microwave reaction vial containing a PTFE-coated magnetic stir bar, $p$-toluidine (64 mg, $0.6 \mathrm{mmol}), \mathrm{KOH}$ ( $84 \mathrm{mg}, 1.5 \mathrm{mmol}$ ) nanocatalyst (15 mg) were added. The reaction vial was closed with a rubber septum. Mixture was evacuated and backfilled with argon and this process was repeated for three times. Under the positive pressure of argon, 1-bromonaphthalene ( $70 \mu \mathrm{L}, 0.5 \mathrm{mmol})$ was added to the reaction mixture. Under inert atmosphere, freshly degassed $1.0 \mathrm{~mL}$ aqueous solution of $3 \mathrm{wt} \%$ PS-750-M was added to the reaction mixture. Reaction mixture was purged with argon for next two minutes. The rubber septum was wrapped with black electrical tape and parafilm. Reaction mixture was stirred at 60 ${ }^{\circ} \mathrm{C}$ for $12 \mathrm{~h}$.

After complete consumption of 1-bromonapthalene as indicated by TLC and GCMS, the mixture was cooled to room temperature. Then, $0.3 \mathrm{~mL}$ warm MTBE was added to the mixture, which was then stirred for 2 minutes at rt. Stirring was stopped and organic layer was allowed to separate. An organic layer was removed using a syringe. This extraction procedure was repeated for one more time (total $0.6 \mathrm{~mL}$ MTBE). The aqueous portion was kept for $1^{\text {st }}$ recycle study. The combined organic layers were dried over anhydrous sodium sulfate. Volatiles were removed under reduced pressure to obtain crude product, which was further purified by a flash chromatography over silica gel using hexanes/ethyl acetate as eluent (1:9), $R_{\mathrm{f}}$ 0.4. Pure product was obtained as dark brown 
viscous oil, yield $108 \mathrm{mg}$ (93\%) (The eluent used in the flash column chromatography was saved for reuse in the next cycle, also see Scheme S5).

1st recycle: The aqueous solution obtained from the above reaction was purged with argon for 10 minutes prior to reuse. To this well purged aqueous solution, $p$-toluidine $(64 \mathrm{mg}, 0.6 \mathrm{mmol}), \mathrm{KOH}$ (56 mg, $1.0 \mathrm{mmol})$ and 1-bromonaphthalene $(70 \mu \mathrm{L}, 0.5 \mathrm{mmol})$ were sequentially added under the positive argon pressure. Reaction vial was closed with a rubber septum. Septum was sealed with a PTFE tape and black electrical tape. The reaction mixture was stirred at $60{ }^{\circ} \mathrm{C}$ for $12 \mathrm{~h}$. After complete consumption of 1-bromonaphthalene as monitored by GCMS, similar extraction and purification procedures were applied as in zeroth cycle. Pure product was obtained as brown oil, yield $105 \mathrm{mg}(90 \%)$. The aqueous part was retained for the $2^{\text {nd }}$ recycle.

iii) 2nd recycle: The $2^{\text {nd }}$ recycle was also achieved following similar procedures as described above; yield $103 \mathrm{mg}(89 \%)$.

iv) 3rd recycle: The $3^{\text {rd }}$ recycle was also achieved following similar procedures as described above; yield $101 \mathrm{mg}(87 \%)$.

v) 4th recycle: The $4^{\text {th }}$ recycle was also achieved following similar procedures as described above; yield $97 \mathrm{mg}$ (83\%). 


\section{EFFECT OF ADDITIONAL $\mathrm{Cu}\left(\mathrm{CH}_{3} \mathrm{CN}\right)_{4} \mathrm{PF}_{6}$ ADDITION ON RECYCLABILITY}

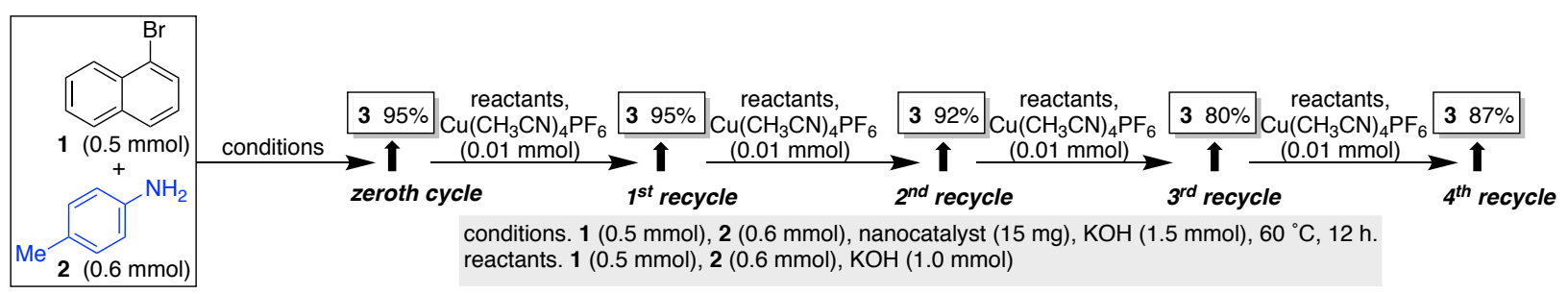

Scheme S6. Effect of additional $\mathrm{Cu}\left(\mathrm{CH}_{3} \mathrm{CN}\right)_{4} \mathrm{PF}_{6}$ on recyclability study and E factor calculation.

Caution. (i) Argon-purged MTBE must be used; (ii) after each cycle, the catalyst containing reaction medium must be purged with argon; (iii) for improved extraction, use warm MTBE.

Zeroth cycle: In a $4.0 \mathrm{~mL}$ flame-dried microwave reaction vial containing a PTFE-coated magnetic stir bar, $p$-toluidine (64 mg, $0.6 \mathrm{mmol}), \mathrm{KOH}$ (84 mg, $1.5 \mathrm{mmol}$ ), and nanocatalyst (15 mg) were added. The reaction vial was closed with a rubber septum. Mixture was evacuated and back-filled with argon and this process was repeated for three times. Under the positive pressure of argon, 1-bromonaphthalene $(70 \mu \mathrm{L}, 0.5 \mathrm{mmol})$ was added to the reaction mixture. Under inert atmosphere, freshly degassed $1.0 \mathrm{~mL}$ aqueous solution of $3 \mathrm{wt} \% \mathrm{PS}-750-\mathrm{M}$ was added to the reaction mixture. Reaction mixture was purged with argon for next two minutes. The rubber septum was wrapped with black electrical tape and parafilm. Reaction mixture was stirred at 60 ${ }^{\circ} \mathrm{C}$ for $12 \mathrm{~h}$.

After $12 \mathrm{~h}, 0.3 \mathrm{~mL}$ warm MTBE was added to the mixture, which was then stirred for 2 minutes at rt. Stirring was stopped and organic layer was allowed to separate. An organic layer was removed using a syringe. This extraction procedure was repeated for one more time (total $0.6 \mathrm{~mL}$ MTBE). After the extraction, the septum was opened and $4.5 \mathrm{mg}$ of $\mathrm{Cu}\left(\mathrm{CH}_{3} \mathrm{CN}\right)_{4} \mathrm{PF}_{6}$ was added under an argon atmosphere. This aqueous portion was kept for $1^{\text {st }}$ recycle study (also see Scheme S6). The combined organic layers were analyzed using GCMS and TLC. GCMS analysis indicated $95 \%$ of product.

1st recycle: The aqueous solution obtained from the above reaction was purged with argon for 10 minutes prior to reuse. To this well purged aqueous solution, $p$-toluidine (64 mg, $0.6 \mathrm{mmol}), \mathrm{KOH}$ (56 mg, $1.0 \mathrm{mmol})$, and 1-bromonaphthalene $(70 \mu \mathrm{L}, 0.5 \mathrm{mmol})$ were sequentially added under the positive argon pressure. Reaction vial was closed with a rubber septum. Septum was sealed 
with a PTFE tape and black electrical tape. The reaction mixture was stirred at $60{ }^{\circ} \mathrm{C}$ for $12 \mathrm{~h}$. Similar extraction and $\mathrm{Cu}\left(\mathrm{CH}_{3} \mathrm{CN}\right)_{4} \mathrm{PF}_{6}$ addition procedures were repeated as in zeroth cycle. GCMS analysis indicated $95 \%$ of product.

iii) 2nd recycle: The $2^{\text {nd }}$ recycle was also achieved following similar procedures as described above; conversion $92 \%$.

iv) 3rd recycle: The $3^{\text {rd }}$ recycle was also achieved following similar procedures as described above; conversion $90 \%$.

v) 4th recycle: The $4^{\text {th }}$ recycle was also achieved following similar procedures as described above; conversion $87 \%$. 


\section{ROLE OF CHARCOAL}

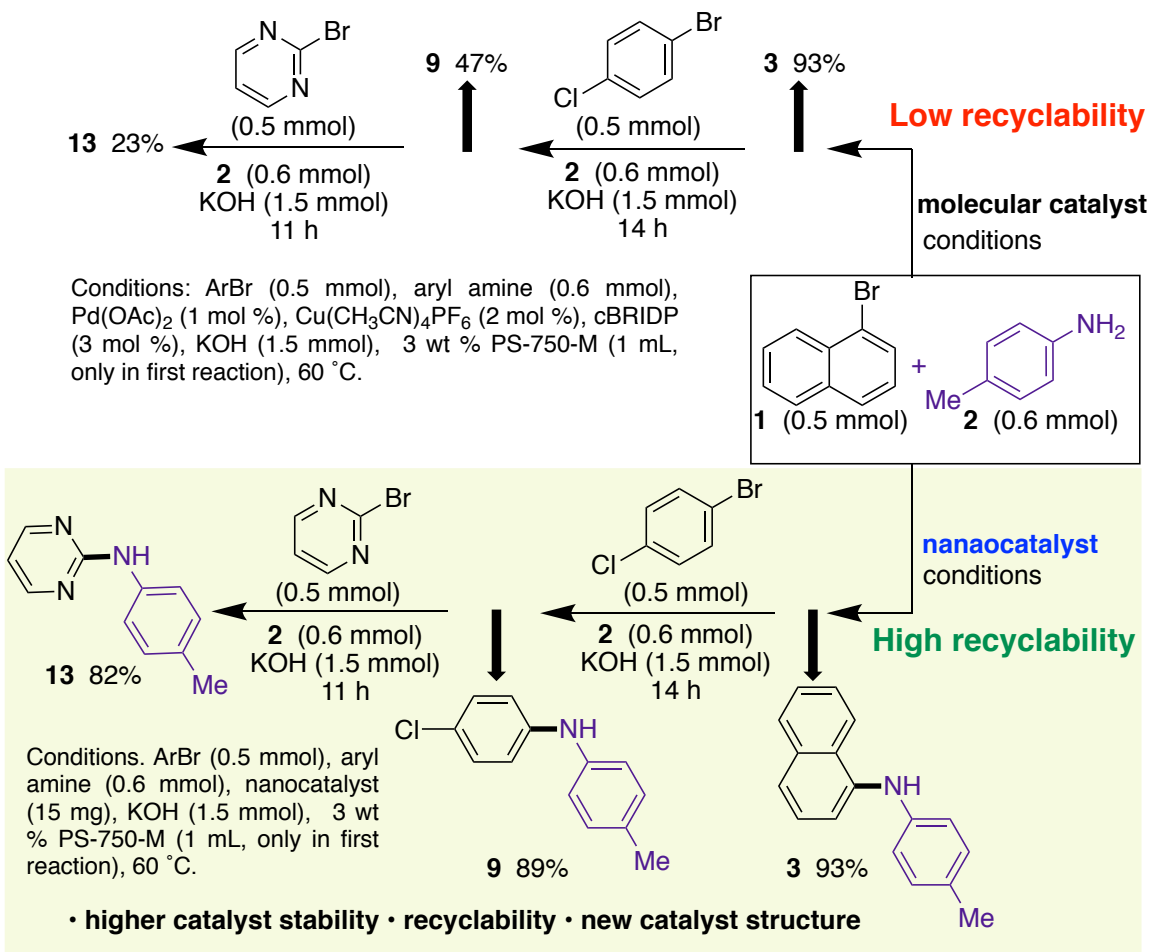

Scheme S7. Role of charcoal on catalyst recyclability

\subsection{Nanoparticles on charcoal - highly recyclable nanocatalyst}

(a) First reaction: In a $4.0 \mathrm{~mL}$ flame-dried microwave reaction vial containing a PTFE-coated magnetic stir bar was charged with $p$-toluidine (64 mg, $0.6 \mathrm{mmol}), \mathrm{KOH}(84 \mathrm{mg}, 1.5 \mathrm{mmol}$ and charcoal-immobilized nanocatalyst $(15 \mathrm{mg})$. The reaction vial was closed with a rubber septum. Mixture was evacuated and back-filled with argon and this process was repeated for three times. Under the positive pressure of argon, 1-bromonaphthalene (70 $\mu \mathrm{L}, 0.5 \mathrm{mmol})$ was added to the vial. Under inert atmosphere, freshly degassed $1.0 \mathrm{~mL}$ aqueous solution of $3 \mathrm{wt} \% \mathrm{PS}-750-\mathrm{M}$ was added to the reaction mixture. Reaction mixture was purged with argon for next two minutes. Rubber septum was further wrapped with PTFE and black electrical tape. Reaction mixture was heated at $60{ }^{\circ} \mathrm{C}$ for $16 \mathrm{~h}$.

After complete consumption of 1-bromonapthalene as indicated by TLC and GCMS, reaction mixture was cooled to rt. Then, $0.5 \mathrm{~mL}$ warm MTBE was added to it and mixture was allowed to stir for $2 \mathrm{~min}$ at rt. Stirring was stopped and organic layer was allowed to separate. An organic layer was removed using a syringe. This extraction procedure was repeated for one more time 
(total $1.0 \mathrm{~mL}$ of MTBE). The aqueous portion was kept for next recycling analysis. The combined extracts were dried over anhydrous sodium sulfate. Volatiles were removed under reduced pressure at room temperature to obtain crude product, which was further purified by a flash chromatography over silica gel using hexanes/ethyl acetate as eluent (1:9), $\mathrm{R}_{f} 0.4$. Pure product was obtained as dark brown viscous oil, yield $108 \mathrm{mg}(93 \%)$.

(b) Second reaction: The aqueous solution obtained from the above reaction was purged with argon for 10 minutes prior to reuse (also see Scheme S7). To this well purged aqueous solution, $p$ toluidine (64 mg, $0.6 \mathrm{mmol}$ ), 4-chlorobromobenzene (95.5 mg, $0.5 \mathrm{mmol}$ ), and KOH (84 mg, 1.5 mmol) were sequentially added under the positive argon pressure. Reaction vial was closed with a rubber septum. Septum was sealed with a PTFE tape and black electrical tape. The reaction mixture was stirred at $60{ }^{\circ} \mathrm{C}$ for $14 \mathrm{~h}$. After complete consumption of starting material as monitored by GCMS, similar extraction procedures were applied as in the above reaction. Pure product was obtained as a white solid ( $96.5 \mathrm{mg}, 89 \%$ yield) after flash column chromatography over silica gel using hexanes/ethyl acetate as eluent (19:1), $\mathrm{R}_{f} 0.3$. The aqueous part was retained for the next reaction.

(c) Third reaction: The aqueous solution obtained from the above reaction was purged with argon for 10 minutes prior to reuse. To this well purged aqueous solution, $p$-toluidine ( $64 \mathrm{mg}, 0.6 \mathrm{mmol})$ and 2-bromopyrimidine (95 mg, $0.5 \mathrm{mmol})$ and $\mathrm{KOH}(84 \mathrm{mg}, 1.5 \mathrm{mmol})$ were sequentially added under the positive argon pressure. Reaction vial was closed with a rubber septum. Septum was sealed with a PTFE tape and black electrical tape. The reaction mixture was stirred at $60{ }^{\circ} \mathrm{C}$ for 11 h. After complete consumption of starting material as monitored by GCMS, similar extraction and purification procedures were applied as in the first cycle. Pure product was obtained as a white solid (76 mg, 82\% yield) after flash column chromatography over silica gel using hexanes/ethyl acetate as eluent (5:1), $\mathrm{R}_{f} 0.4$.

\subsection{Nanoparticles without charcoal - low recyclability}

(a) First reaction: In a $4 \mathrm{~mL}$ oven dried-reaction vial, $0.05 \mathrm{M}(1 \mathrm{~mL})$ stock solution of palladium(II) acetate was prepared in dry THF. In another oven-dried $4 \mathrm{~mL}$ reaction vial equipped with PTFE-coated stir bar, tetrakis(acetonitrile)copper(I) hexafluorophosphate (3.7 mg, 0.01 mmol) and cBRIDP (5.3 mg, $0.015 \mathrm{mmol})$ were added. The vessel was closed with a rubber septum 
and under inert atmosphere, $0.1 \mathrm{~mL}$ of $\mathrm{Pd}(\mathrm{OAc})_{2}$ from a stock solution was added to it. Mixture was gently heated with a heat gun to obtain dark red color mixture. Reaction mixture was heated at $60{ }^{\circ} \mathrm{C}$ for additional $15 \mathrm{~min}$. After evaporating THF under vacuum, the vial was charged with p-toluidine (64 mg, $0.5 \mathrm{mmol})$ and $\mathrm{KOH}(84 \mathrm{mg}, 1.5 \mathrm{mmol})$. The reaction vial was closed with a rubber septum. Mixture was evacuated and back-filled with argon and this process was repeated for three times. Under the positive pressure of argon, 1-bromonaphthalene ( $70 \mu \mathrm{L}, 0.5 \mathrm{mmol})$ were then added. Freshly degassed $1.0 \mathrm{~mL}$ aqueous solution of 3 wt \% PS-750-M was added to the reaction mixture. The mixture was purged with argon for next two minutes. Reaction mixture was stirred for $16 \mathrm{~h}$ at $60{ }^{\circ} \mathrm{C}$.

After complete consumption of 1-bromonapthalene, as indicated by TLC and GCMS, the mixture was cooled to room temperature. $0.5 \mathrm{~mL}$ warm MTBE was added and mixture was stirred for 2 min at rt. Stirring was stopped and organic layer was allowed to separate. An organic layer was removed using a syringe. This extraction procedure was repeated for one more time (total $1.0 \mathrm{~mL}$ of MTBE). An aqueous portion was kept for second reaction. The combined extracts were dried over anhydrous sodium sulfate. Volatiles were removed under reduced pressure at $\mathrm{rt}$ to obtain crude product, which was further purified by a flash chromatography over silica gel using hexanes/ethyl acetate as eluent (1:9), $R_{\mathrm{f}}=0.4$. Pure product was obtained as dark brown viscous oil, yield $114 \mathrm{mg}(98 \%)$.

(b) Second reaction: An aqueous solution obtained from the above reaction was purged with argon for 10 minutes prior to reuse. To this well purged aqueous solution, $p$-toluidine (64 mg, 0.6 mmol), 4-chlorobromobenzene (95.5 mg, $0.5 \mathrm{mmol})$, and $\mathrm{KOH} \mathrm{(84} \mathrm{mg,} 1.5 \mathrm{mmol}$ ) were sequentially added under the positive argon pressure. Reaction vial was closed with a rubber septum. Septum was sealed with a PTFE tape and black electrical tape. The reaction mixture was stirred at $60{ }^{\circ} \mathrm{C}$ for $15 \mathrm{~h}$. After $14 \mathrm{~h}$, similar extraction procedures were applied as in the above reaction. Pure product was obtained as a white solid after flash column chromatography (hexanes/EtOAc, 19:1 $\mathrm{R}_{f} 0.3$ ), yield $51 \mathrm{mg}(47 \%)$. An aqueous part was retained for the next reaction.

(c) Third reaction: An aqueous solution obtained from the above reaction was purged with argon for 10 minutes prior to reuse. To this well purged aqueous solution, $p$-toluidine ( $64 \mathrm{mg}, 0.6 \mathrm{mmol}$ ), 
2-bromopyrimidine ( $95 \mathrm{mg}, 0.5 \mathrm{mmol}$ ), and $\mathrm{KOH}(84 \mathrm{mg}, 1.5 \mathrm{mmol}$ ) were sequentially added under the positive argon pressure. Reaction vial was closed with a rubber septum. Septum was sealed with a PTFE tape and black electrical tape. The reaction mixture was stirred at $60^{\circ} \mathrm{C}$ for 21 h. After $11 \mathrm{~h}$, similar extraction and purification procedures were applied as in the first cycle. Pure product was obtained as a white solid after flash column chromatography (hexanes:EtOAc, 5:1 $\mathrm{R}_{f}$ $0.4)$, yield $20 \mathrm{mg}(22 \%)$.

\subsection{Continuation of catalytic pathway}

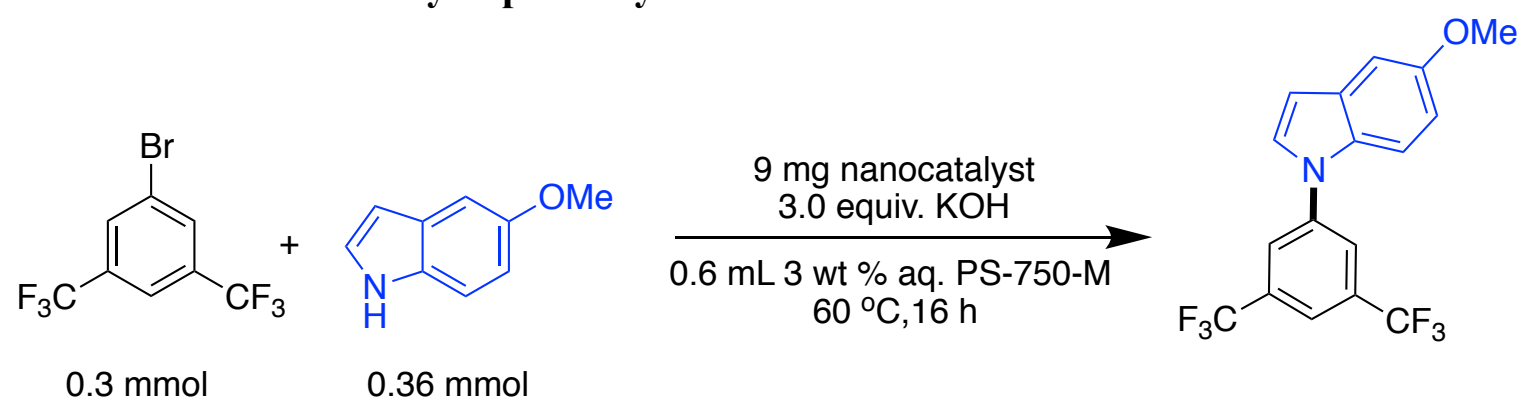

Scheme S8. Continuous reactions without isolation.

5-Methoxy-1 $H$-indole (53 mg, $0.6 \mathrm{mmol})$, nanocatalyst $(9 \mathrm{mg})$, and $\mathrm{KOH}(50.4 \mathrm{mg}, 0.9 \mathrm{mmol})$ were added into the $4 \mathrm{~mL}$ oven-dried reaction vial containing PTFE-coated stirrer bar. Reaction vial was evacuated and back-filled with argon for three times. 1-Bromo-3,5bis(trifluoromethyl)benzene ( $51 \mu \mathrm{L}, 0.3 \mathrm{mmol}$ ) and $0.6 \mathrm{~mL}$ aqueous solution of PS-750-M was added to the reaction mixture. Reaction mixture was purged with argon for 2 minutes and then stirred for $16 \mathrm{~h}$ at $60{ }^{\circ} \mathrm{C}$ (Scheme S8). After complete consumption of starting material as monitored by TLC, reaction mixture was allowed to cool to rt. Without isolating the product, another batch of reactants were introduced into the reaction mixture, i.e., 1-bromo-3,5bis(trifluoromethyl)benzene (51 $\mathrm{L}, 0.3 \mathrm{mmol}), 5$-methoxy- $1 H$-indole $(53 \mathrm{mg}, 0.6 \mathrm{mmol})$, and $\mathrm{KOH}(50.4 \mathrm{mg}, 0.9 \mathrm{mmol})$. Reaction vial was evacuated and back-filled with argon. Reaction mixture was purged with argon for 2 minutes and then stirred for $16 \mathrm{~h}$ at $60^{\circ} \mathrm{C}$. Reaction progress monitoring using GCMS. After complete consumption of starting material, reaction mixture was allowed to cool to rt. Without isolating the product, another batch of reactants were introduced into the reaction mixture, i.e., 1-bromo-3,5-bis(trifluoromethyl)benzene (51 $\mu \mathrm{L}, 0.3 \mathrm{mmol})$, 5methoxy-1H-indole (53 mg, $0.6 \mathrm{mmol})$, and $\mathrm{KOH}(50.4 \mathrm{mg}, 0.9 \mathrm{mmol})$. Reaction vial was 
evacuated and back-filled with argon. Reaction mixture was purged with argon for 2 minutes and then stirred for $16 \mathrm{~h}$ at $60{ }^{\circ} \mathrm{C}$. Reaction progress monitoring using GCMS. After complete consumption of starting material, reaction mixture was allowed to cool to rt. EtOAc $(0.5 \mathrm{~mL})$ was added to the reaction mixture and stirred for a minute at rt. Stirring was stopped and organic layer was allowed to separate. Organic layer was withdrawn with the aid of syringe needle. This extraction process was repeated for an additional time. Combined organic layers were dried over anhydrous sodium sulfate. Volatiles were removed under reduce pressure to obtain crude product. Crude product was purified by flash chromatography over silica gel using EtOAc/hexanes as eluent ( $\mathrm{R}_{f}$ 0.4, 1:4 EtOAc/hexanes), yield $297.2 \mathrm{mg}$ (92\% over all isolated yield).

\subsection{Confirming the heterogeneity of catalyst - filtration test}

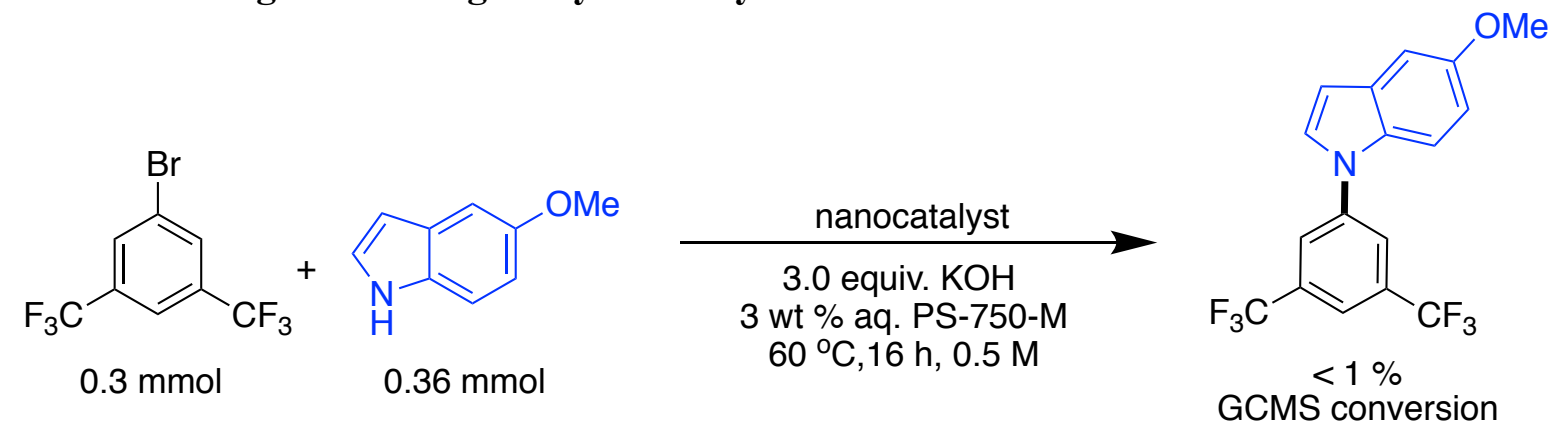

Scheme S9. Metal leaching study by filtration.

In a $4 \mathrm{~mL}$ oven-dried reaction vial containing PTFE-coated stirrer-bar was charged with nanocatalyst $(9 \mathrm{mg})$. The reaction vial was closed with a rubber septum and evacuated and backfilled with argon three times. Later, $0.6 \mathrm{~mL}$ of $3 \mathrm{wt} \%$ aq. solution of PS-750-M was added, and the mixture was stirred for the next two hours at $60{ }^{\circ} \mathrm{C}$. Later, the obtained turbid solution (small black particles) was filtered using glass fiber filter paper to another oven-dried $4 \mathrm{~mL}$ reaction vial which already contained PTFE-coated stirrer-bar, 5-methoxyindole (53 mg, 0.36 $\mathrm{mmol}$ ), and $\mathrm{KOH}(50.4 \mathrm{mg}, 0.9 \mathrm{mmol})$. The reaction vial was closed with a rubber septum and evacuated and backfilled with argon three times (cautions: appropriate technique must be used to avoid the entry of foams to the vacuum/argon line). Later, 3,5-bistrifluoromthylbromobenezene (51 $\mu \mathrm{L}, 0.3 \mathrm{mmol}$ ) was added, and the septum was wrapped with parafilm. The reaction mixture was purged with argon for $2 \mathrm{~min}$. The reaction vial was stirred for the next $16 \mathrm{~h}$ at $60{ }^{\circ} \mathrm{C}$ (Scheme S9). Later, the mixture was cooled to room temperature. The septum was removed and $0.5 \mathrm{~mL}$ EtOAc was added to the reaction mixture, which was then stirred for a minute at rt. Stirring was 
stopped, and the organic layer was allowed to separate from the aqueous layer. The organic layer was removed with the help of a pipette. This extraction process was repeated for additional time. An aliquot from this organic layer was analyzed using GCMS and TLC ( $\mathrm{R}_{f}$ 0.4, 4:1 Hex: EtOAc). GCMS indicated traces of product formation $(<1 \%)$. 


\section{KINETIC STUDY ON RECYCLABILITY OF CATALYST}

\section{Outline of a plan for kinetic studies (see Scheme S10 below)}
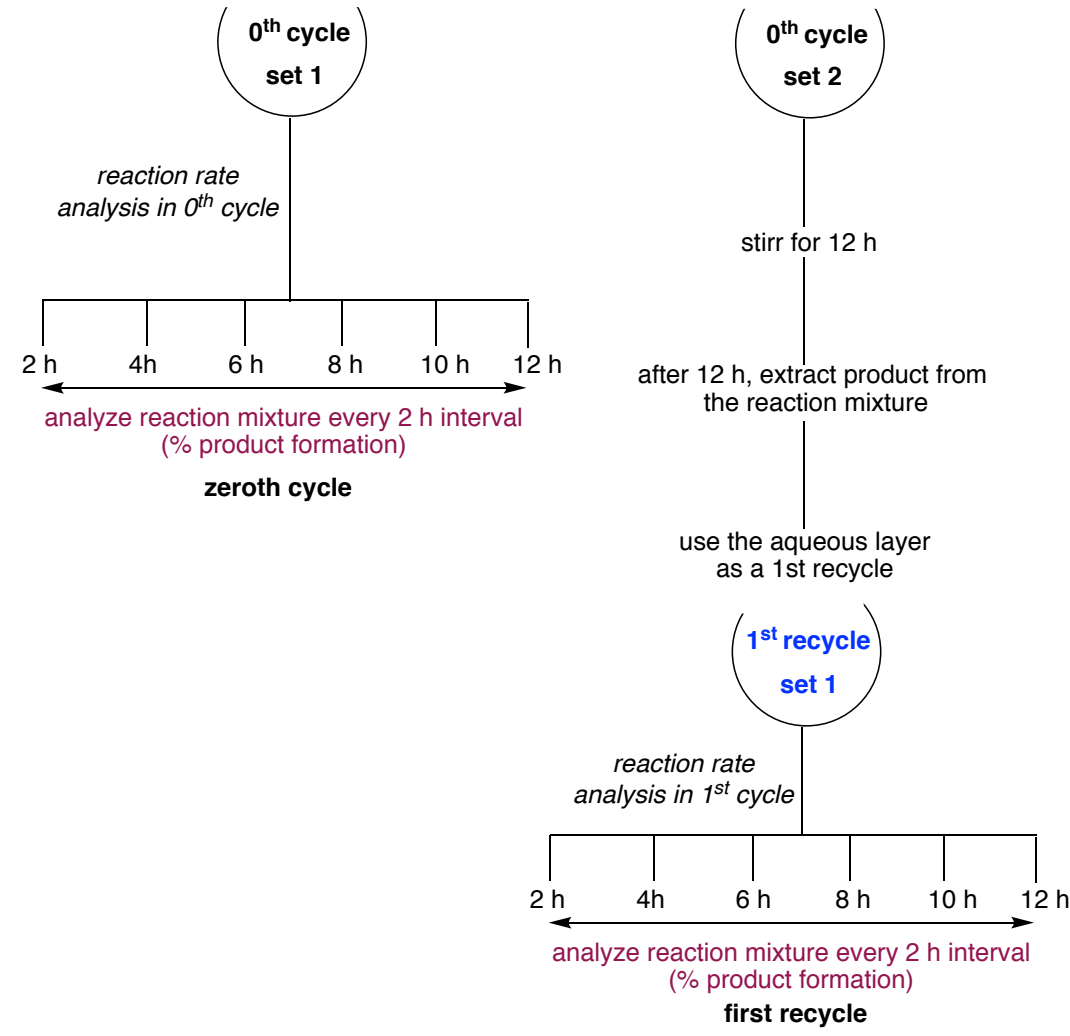

after $12 \mathrm{~h}$, extract product from the reaction mixture

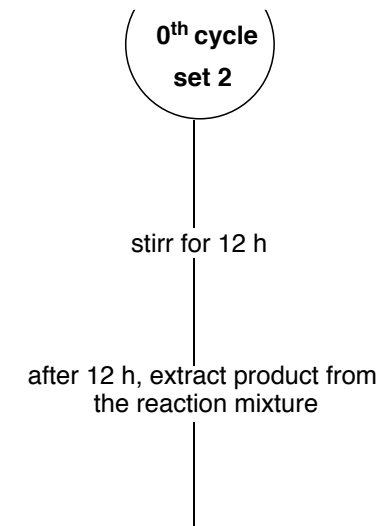

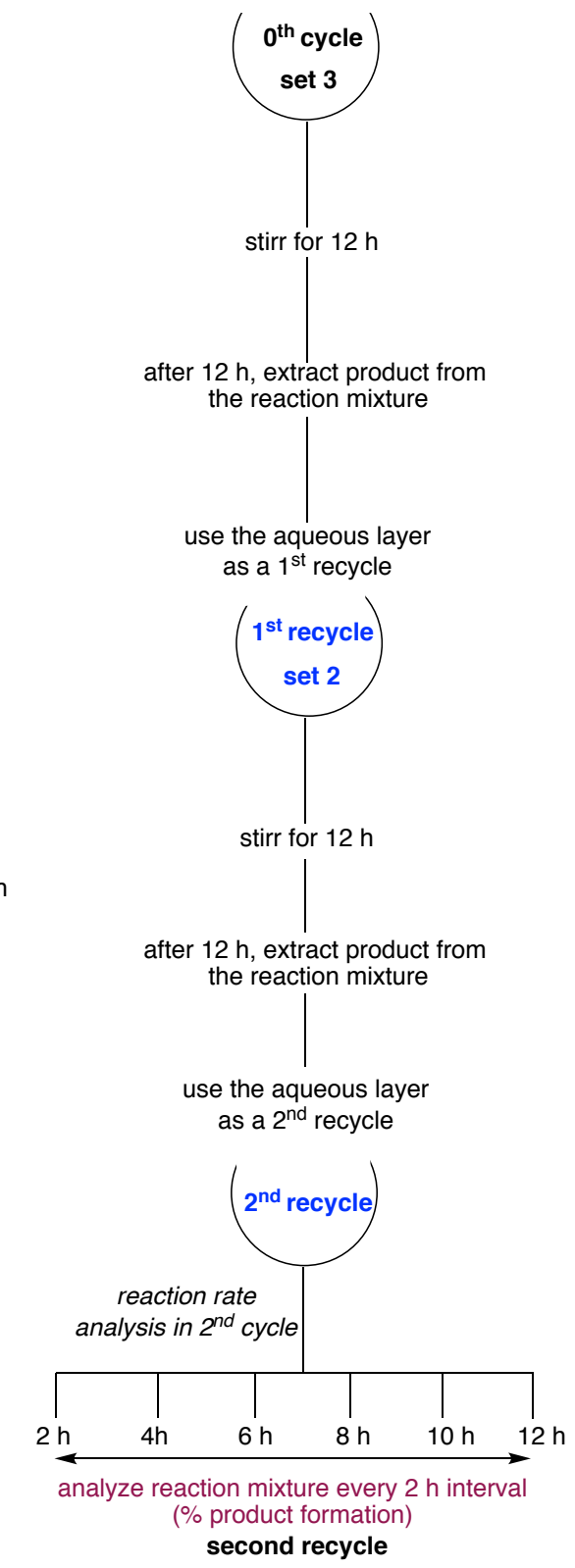

Scheme S10. Role of charcoal on catalyst recyclability 


\section{Procedure}<smiles>Brc1cccc2ccccc12</smiles>

$1.0 \mathrm{mmol}$

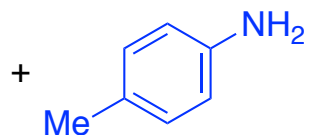

$1.2 \mathrm{mmol}$

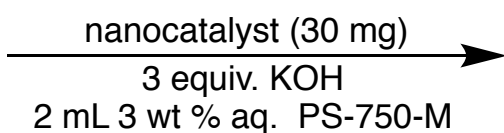

$60^{\circ} \mathrm{C}, 12 \mathrm{~h}$

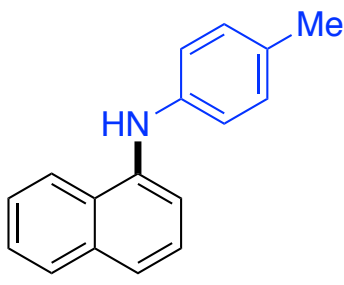

3

Scheme S11. Kinetic study on recyclability of catalyst.

In a $4.0 \mathrm{~mL}$ flame-dried microwave reaction vial containing a PTFE-coated magnetic stir bar, $p$ toluidine (128.4 mg, $1.2 \mathrm{mmol}), \mathrm{KOH}$ (168 mg, $3 \mathrm{mmol}$ ), and nanocatalyst (30 mg) were added. The reaction vial was closed with a rubber septum. The mixture was evacuated and backfilled with argon, and this process was repeated for three times. Under the positive pressure of argon, 1bromonaphthalene (140 $\mu \mathrm{L}, 1 \mathrm{mmol})$ was added to the reaction mixture. Under an inert atmosphere, a freshly degassed $2.0 \mathrm{~mL}$ aqueous solution of $3 \mathrm{wt} \%$ PS-750-M was added to the reaction mixture. The reaction mixture was purged with argon for the next two minutes. The rubber septum was wrapped with black electrical tape and parafilm. The reaction mixture was transferred to a preheated well plate at $60^{\circ} \mathrm{C}$ and allowed to stir. After $2 \mathrm{~h}$, under vigorous stirring conditions, an aliquot of $50 \mu \mathrm{L}$ (equivalent to $0.025 \mathrm{mmol}$ ) was withdrawn from the vial without disturbing any key reaction parameters (temperature and argon atmosphere). The aliquot was diluted with 1 $\mathrm{mL}$ EtOAc containing $0.87 \mu \mathrm{L}(0.25$ equiv. to aliquot or $0.00625 \mathrm{mmol})$ of mesitylene [to ensure accuracy, a stock solution of $8.7 \mu \mathrm{L}$ mesitylene in $10 \mathrm{~mL}$ EtOAc was prepared and $1.0 \mathrm{~mL}$ from this solution was used each time to dilute the $50 \mu \mathrm{L}$ aliquot]. The diluted $1.0 \mathrm{~mL}$ mixture was passed through a silica pad to remove metal impurities, and organic layer was analyzed using GCMS. Following a same protocol, reaction mixture was analyzed for every $2 \mathrm{~h}$ interval until 12 $\mathrm{h}$ of reaction.

Following a plan for the kinetic studies as outlined on last page, a separate, undisturbed similar reaction set was kept for $12 \mathrm{~h}$ at $60{ }^{\circ} \mathrm{C}$, later the mixture was treated with $0.3 \mathrm{~mL}$ warm MTBE, which was then stirred for 2 minutes at rt. Stirring was stopped and organic layer was allowed to separate. An organic layer was removed using a syringe. This extraction procedure was repeated for one more time (total $0.6 \mathrm{~mL}$ MTBE). The aqueous portion was kept for $1^{\text {st }}$ recycle.

The aqueous solution obtained from the above was purged with argon for 10 minutes prior to reuse. To this well purged aqueous solution, $p$-toluidine (128 mg, $1.2 \mathrm{mmol}), \mathrm{KOH}$ (168 mg, $3 \mathrm{mmol}$ ), 
and 1-bromonaphthalene $(140 \mu \mathrm{L}, 1 \mathrm{mmol})$ were sequentially added under the positive argon pressure. Reaction vial was closed with a rubber septum and sealed with a PTFE tape and black electrical tape. The reaction mixture was stirred at $60{ }^{\circ} \mathrm{C}$. After $2 \mathrm{~h}$, under vigorous stirring conditions, an aliquot of $50 \mu \mathrm{L}$ (equivalent to $0.025 \mathrm{mmol}$ ) was withdrawn from the vial without disturbing any key reaction parameters (temperature and argon atmosphere). The aliquot was diluted with $1.0 \mathrm{~mL}$ EtOAc containing $0.87 \mu \mathrm{L}(0.25$ equiv. to aliquot or $0.00625 \mathrm{mmol})$ of mesitylene [to ensure accuracy, a stock solution of $8.7 \mu \mathrm{L}$ mesitylene in $10 \mathrm{~mL}$ EtOAc was prepared and $1 \mathrm{~mL}$ from this solution was used each time to dilute the $50 \mu \mathrm{L}$ aliquot]. The diluted $1.0 \mathrm{~mL}$ mixture was passed through a silica pad to remove metal impurities and analyzed using GCMS. Following a same protocol, reaction mixture was analyzed for every $2 \mathrm{~h}$ interval until 12 $\mathrm{h}$ of reaction.

For the second recycle, a plan described in the outline was exactly followed. This aqueous solution was purged with argon for 10 minutes prior to reuse. To this well purged aqueous solution, $p$ toluidine (128 mg, $1.2 \mathrm{mmol}), \mathrm{KOH}(168 \mathrm{mg}, 3 \mathrm{mmol})$ and 1-bromonaphthalene (140 $\mu \mathrm{L}, 1 \mathrm{mmol})$ were sequentially added under the positive argon pressure. Reaction vial was closed with a rubber septum and sealed with a PTFE tape and black electrical tape. The reaction mixture was stirred at $60^{\circ} \mathrm{C}$. After $2 \mathrm{~h}$, under vigorous stirring conditions, an aliquot of $50 \mu \mathrm{L}$ (equivalent to $0.025 \mathrm{mmol}$ ) was withdrawn from the vial without disturbing any key reaction parameters (temperature and argon atmosphere). The aliquot was diluted with $1 \mathrm{~mL}$ EtOAc containing $0.87 \mu \mathrm{L}$ ( 0.25 equiv. to aliquot or $0.00625 \mathrm{mmol}$ ) of mesitylene [to ensure accuracy, a stock solution of $8.7 \mu \mathrm{L}$ mesitylene in $10 \mathrm{~mL}$ EtOAc was prepared and $1 \mathrm{~mL}$ from this solution was used each time to dilute the $50 \mu \mathrm{L}$ aliquot]. The diluted $1.0 \mathrm{~mL}$ mixture was passed through a silica pad to remove metal impurities and analyzed using GCMS. Following a same protocol, reaction mixture was analyzed for every $2 \mathrm{~h}$ interval until $12 \mathrm{~h}$ of reaction.

Note-Following precautions must be taken to get consistent results (i) vigorous stirring must be ensured while withdrawing aliquots, this will guarantee homogeneity, (ii) argon purged MTBE must be used, (iii) after each cycle, the catalyst-containing reaction medium must be purged with argon. 

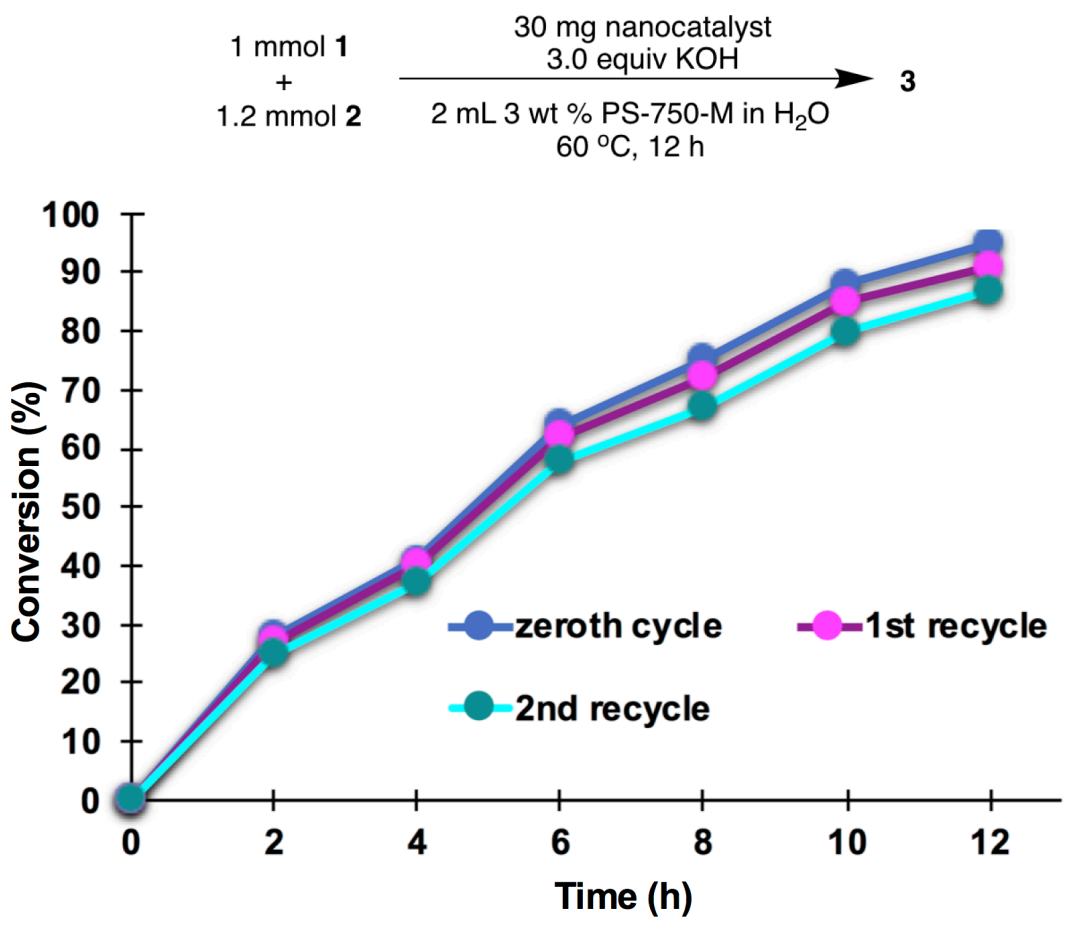

Figure S2. Kinetic studies as a valid assessment regarding the stability of catalyst. 


\section{SONOGASHIRA COUPLINGS USING NANOCATALYST}

Hetero/aryl bromide $(0.3 \mathrm{mmol})$, alkyne $(0.36 \mathrm{mmol})$, nanocatalyst $(9.0 \mathrm{mg})$, and $\mathrm{KOH}(50.4 \mathrm{mg}$, 0.9 mmol) were added into the $4 \mathrm{~mL}$ oven-dried reaction vial containing PTFE-coated stirrer-bar. Reaction vial was closed with a rubber septum. Vessel was quickly evacuated and back-filled with argon. To this mixture, $0.6 \mathrm{~mL}$ aqueous solution of $3 \mathrm{wt} \% \mathrm{PS}-750-\mathrm{M}$ was added. Reaction mixture was purged with argon for $2 \mathrm{~min}$. Reaction mixture was stirred at $60^{\circ} \mathrm{C}$. After the complete consumption of starting material indicated by TLC and GCMS, the mixture was cooled to room temperature. $0.5 \mathrm{~mL}$ EtOAc was added and mixture was stirred for a minute at rt. Organic and aqueous layers were allowed to separate. An organic layer was withdrawn with pipette. This extraction process was repeated for an additional time. Combined organic layers were dried over anhydrous sodium sulfate. Volatiles were removed under reduced pressure to obtain the crude product (see Table S12). The crude mixture was further purified by flash chromatography over silica gel using EtOAc/hexanes as eluent.

Table S12. Substrate scope for the Sonogashira coupling using nanocatalyst

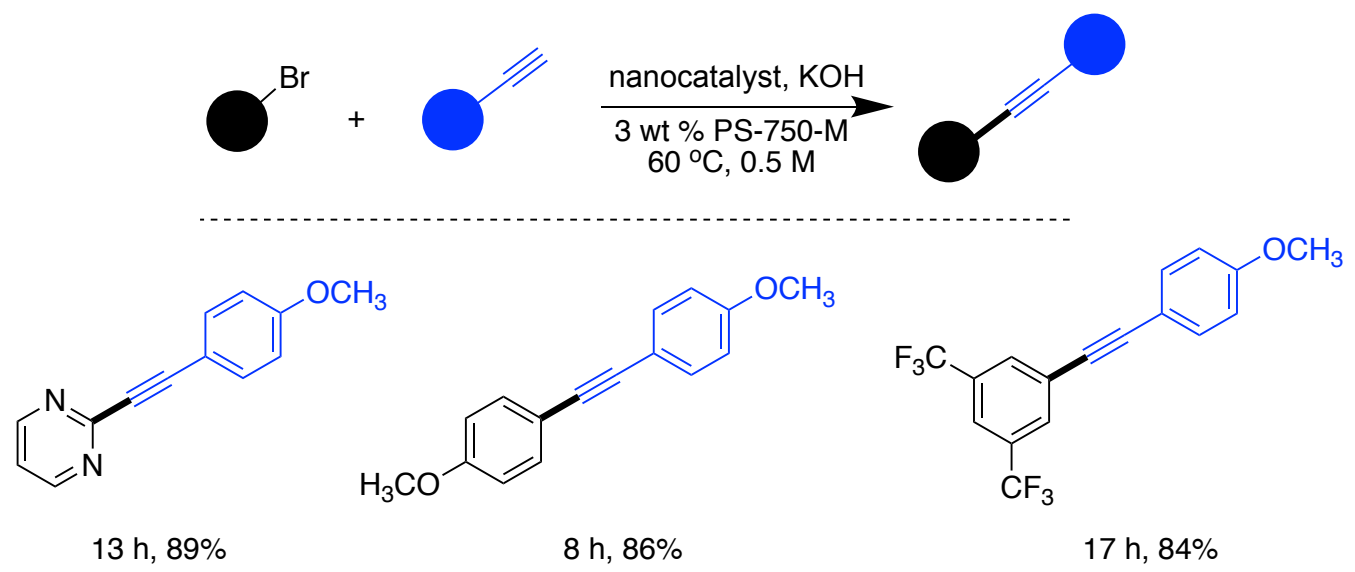

Conditions: hetero/arylbromide $(0.3 \mathrm{mmol})$, alkyne $(0.36 \mathrm{mmol})$, ), Isolated charcoal nanocatalyst $(9 \mathrm{mg}), \mathrm{KOH}(0.9 \mathrm{mmol}), 0.6$ $\mathrm{mL} 3 \mathrm{wt} \%$ aq. PS-750-M, $60{ }^{\circ} \mathrm{C}, 12 \mathrm{~h}$, all yields are isolated. 


\section{SUZUKI-MIYAURA COUPLINGS USING NANOCATALYST}

Hetero/aryl bromide $(0.3 \mathrm{mmol})$, arylboronic acid/MIDA ester $(0.36 \mathrm{mmol})$, nanocatalyst $(9.0 \mathrm{mg})$, and $\mathrm{KOH}(50.4 \mathrm{mg}, 0.9 \mathrm{mmol})$ were added into $4 \mathrm{~mL}$ oven-dried reaction vial containing PTFEcoated stirrer-bar. Reaction vial was closed with a rubber septum. Reaction vial was evacuated and backfilled with argon. To this mixture, $0.6 \mathrm{~mL}$ aqueous solution of $3 \mathrm{wt} \%$ PS-750-M was added. Reaction mixture was purged with argon for $2 \mathrm{~min}$. Reaction mixture was stirred at $60{ }^{\circ} \mathrm{C}$. After complete consumption of starting material as monitored by TLC and GCMS, mixture was cooled to rt. $0.5 \mathrm{~mL}$ EtOAc was added and mixture stirred for a minute at rt. Stirring was stopped and two layers were allowed to separate. An organic layer was taken out with use of pipetted. This extraction process was repeated for an additional time. Combined organic layers were dried over anhydrous sodium sulfate. Volatiles were removed under reduced pressure to obtain crude product, which was further purified by flash chromatography over silica gel using EtOAc/hexanes as eluent (see Table S13).

Table S13. Substrate scope for the Suzuki-Miyaura coupling using nanocatalyst

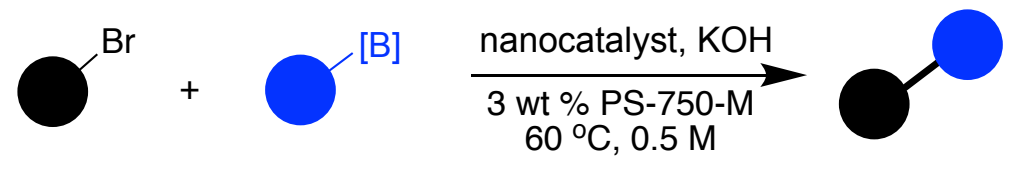

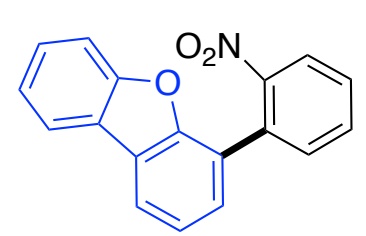

$19 \mathrm{~h}, 73 \%$

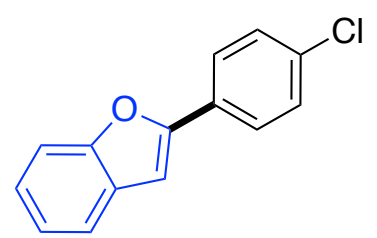

12 h, $89 \%$

Conditions: hetero/arylbromide $(0.3 \mathrm{mmol})$, boronate ester/acid $(0.36 \mathrm{mmol})$, Isolated charcoal nanocatalyst $(9 \mathrm{mg}), \mathrm{KOH}(0.9$ $\mathrm{mmol}), 0.6 \mathrm{~mL} 3 \mathrm{wt} \%$ aq. PS-750-M, $60^{\circ} \mathrm{C}$, all yields are isolated. 


\section{ICP-MS ANALYSIS OF A SAMPLE PRODUCT}

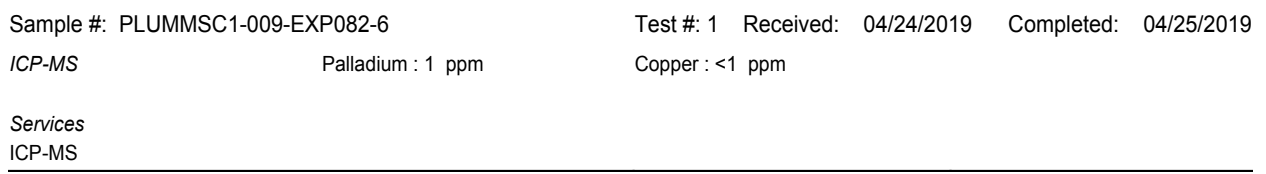

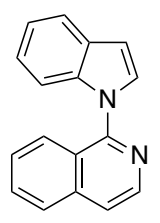

\section{DLS EXPERIMENTS FOR PARTICLE SIZE DETERMINATION}

\subsection{DLS analysis at rt (also see Figure S3)}

(a) $0.3 \mathrm{wt} \%$ PS-750-M in water. Average particle size is $129.4 \mathrm{~nm}$.

(b) Nanocatalyst in 0.3 wt \% PS-750-M. Nanocatalyst (1 mg) was dispersed in $10 \mathrm{~mL} 0.3 \mathrm{wt} \%$ aq. solution of PS-750-M. Resulting suspension was filtered to through a membrane filter (pore size $2 \mu \mathrm{m}$ ) and clean solution was analyzed for particle size distribution. Average particle size was $535.4 \mathrm{~nm}$.

(c) 1-Bromonaphthalene in 0.3 wt \% PS-750-M. 1-bromonapthalene ( $7 \mu \mathrm{L})$ was dissolved in 10 $\mathrm{mL} 0.3 \mathrm{wt} \%$ aq. solution of PS-750-M. Resulting mixture was vigorously stirred for $30 \mathrm{~min}$. and the mixture was filtered through a membrane filter (pore size $2 \mu \mathrm{m}$ ). A drop of THF was added to the solution. The obtained clean solution was analyzed for particle size distribution. Average particle size was $683.2 \mathrm{~nm}$.

(d) 1-Bromonaphthalene and nanocatalyst in $0.3 \mathrm{wt} \%$ PS-750-M. To the nanocatalyst in 0.3 wt \% PS-750-M sample prepared above, 1-bromonapthalene $(7 \mu \mathrm{L})$ was added. The solution was vigorously stirred 30 minutes and filtered through a membrane filter (pore size $2 \mu \mathrm{m}$ ). Cloudiness was removed by adding one drop of THF. A drop of THF was added to the solution. The obtained clean solution was analyzed for particle size distribution. Average particle size was $1220.4 \mathrm{~nm}$. 

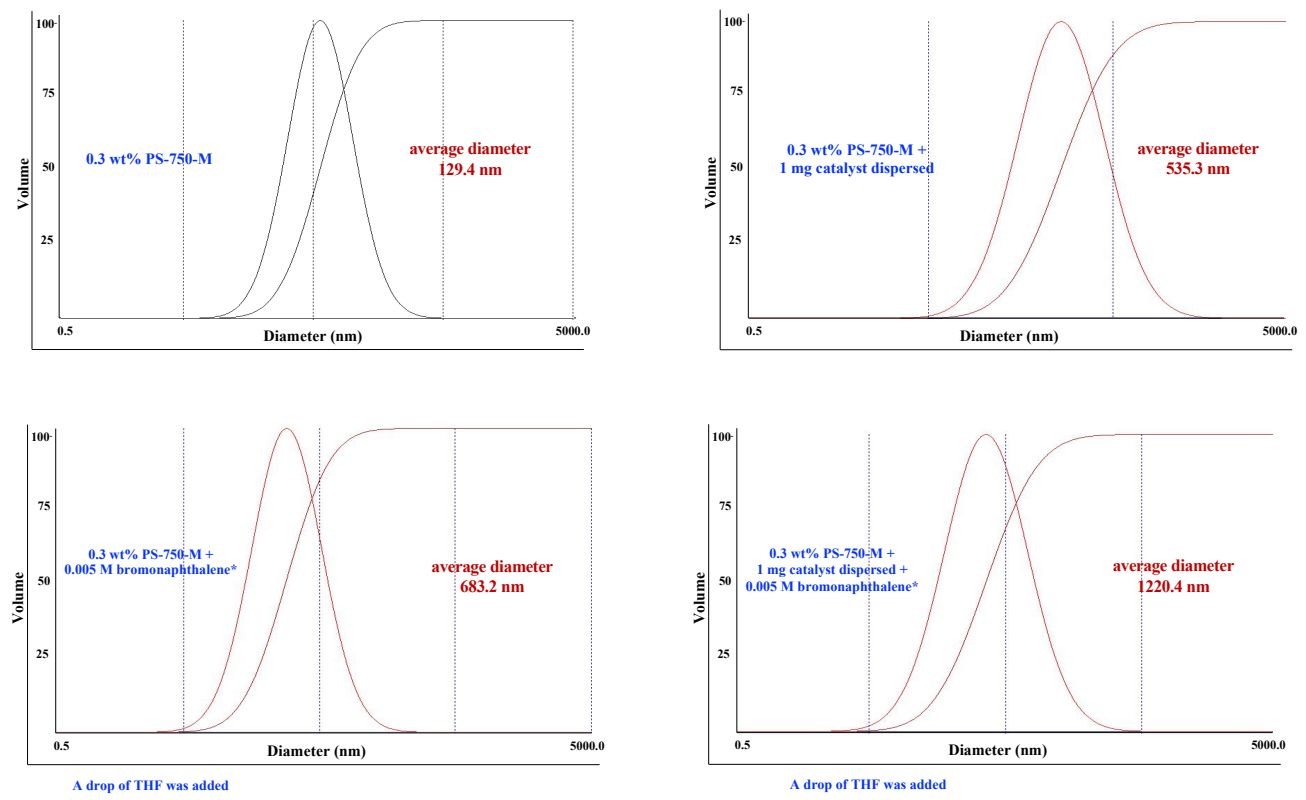

Figure S3. DLS studies at $25^{\circ} \mathrm{C}$.

\subsection{DLS analysis at $60^{\circ} \mathrm{C}$ (see Figure $\mathrm{S} 4$ below)}
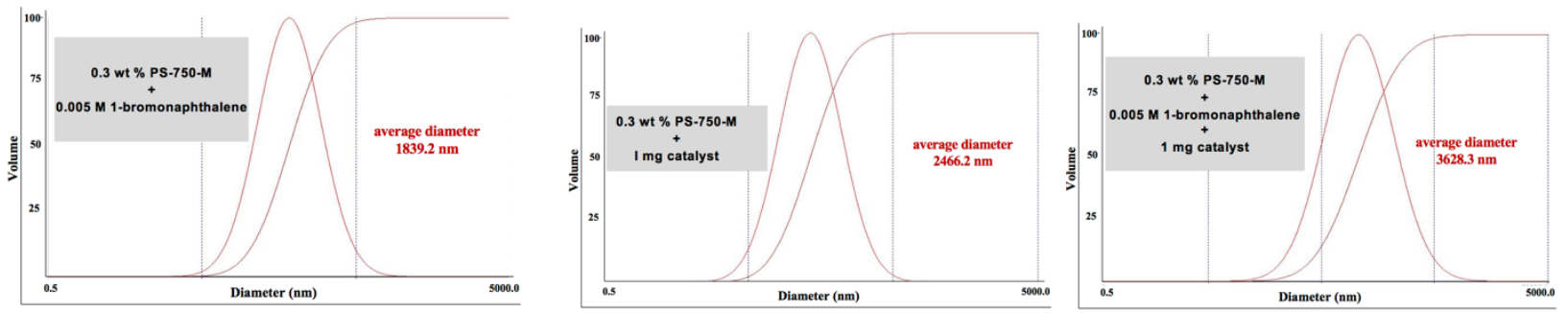

Figure S4. DLS studies at $60^{\circ} \mathrm{C}$. 


\section{DETALIED ANALYSIS OF NANOCATALYST}

\section{S17.1 Analysis by NMR spectroscopy}

(a) Sample preparation. All samples described in Table S14 were heated at $60{ }^{\circ} \mathrm{C}$ under inert atmosphere for 15 minutes.

Table S14. Sample details for the NMR experiments

\begin{tabular}{c|c}
\hline Sample ID & Constituents \\
\hline Sample-A & $2.8 \mathrm{mg}$ cBRIDP in $0.5 \mathrm{~mL}$ dry dmso-d6 under inert atmosphere \\
Sample-B & $2.8 \mathrm{mg} \mathrm{cBRIDP}$ and $1.8 \mathrm{mg} \mathrm{Pd}(\mathrm{OAc})_{2}$ in $0.5 \mathrm{~mL}$ dry dmso-d6 \\
Sample-C & $2.8 \mathrm{mg} \mathrm{cBRIDP}, 0.6 \mathrm{mg} \mathrm{Pd}(\mathrm{OAC})_{2}$, and $1.98 \mathrm{mg} \mathrm{Cu}\left(\mathrm{CH}_{3} \mathrm{CN}\right)_{4} \mathrm{PF}_{6}$ in $0.5 \mathrm{~mL}$ dry dmso-d6 \\
Sample-D & $2.8 \mathrm{mg}$ cBRIDP and $1.98 \mathrm{mg} \mathrm{Cu}\left(\mathrm{CH}_{3} \mathrm{CN}\right)_{4} \mathrm{PF}_{6}$ in $0.5 \mathrm{~mL}$ dry dmso-d6 \\
Sample-E & $2.8 \mathrm{mg} \mathrm{cBRIDP}, 0.6 \mathrm{mg} \mathrm{Pd}(\mathrm{OAC})_{2}, 1.98 \mathrm{mg} \mathrm{Cu}\left(\mathrm{CH}_{3} \mathrm{CN}_{4}\right)_{4} \mathrm{PF}_{6}$, and charcoal in $0.5 \mathrm{~mL}$ dry \\
& $\mathrm{dmso-d6}$ \\
\hline
\end{tabular}

(b) NMR experiments. All experiments were carried out in Varian Innova $400 \mathrm{MHz}$ NMR at 25 ${ }^{\circ} \mathrm{C}$. DMSO $\left(\mathrm{d}_{6}\right)$ as NMR solvent and $\mathrm{PPh}_{3}$ as internal standard were used in each experiment. From above stock solutions, $0.1 \mathrm{~mL}$ analyte was withdrawn and further diluted with $0.4 \mathrm{~mL} \mathrm{DMSO}\left(\mathrm{d}_{6}\right)$. Resulting sample was analyzed by NMR spectroscopy as illustrated in Figure S5.

(Note: The internal standard was prepared in a capillary tube by dissolving $\mathrm{PPh}_{3}$ in DMSO(d6) in a capillary tube, and tip of capillary tube was permanently sealed) 

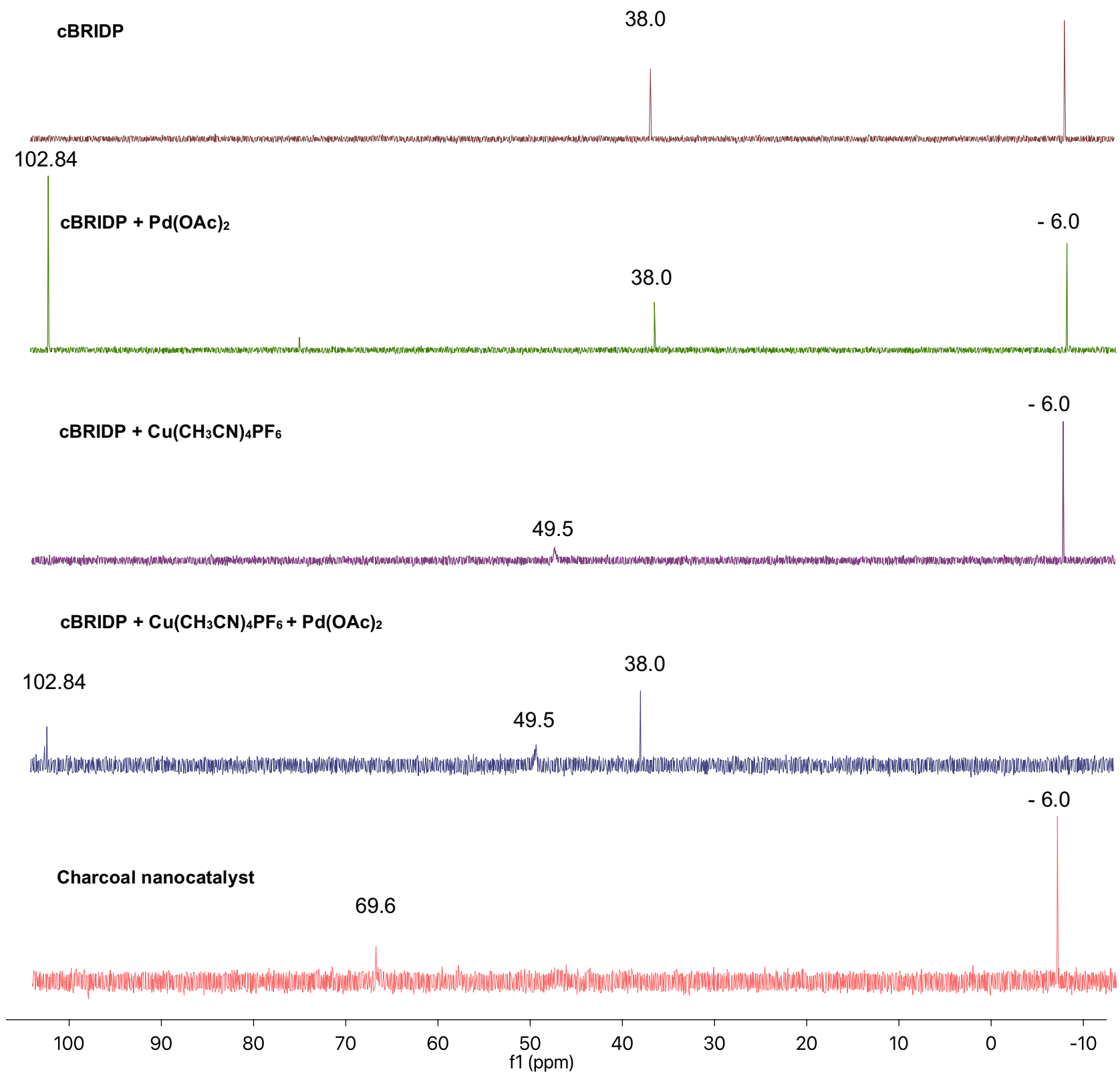

Figure S5. ${ }^{31} \mathrm{P}$ NMR studies on the catalyst.

- A signal at -6.0 ppm is from $\mathrm{PPh}_{3}$, an internal stnadard

- A peak at 38 ppm is from ${ }^{31} \mathrm{P}$ signal of cBRIDP

- A peak at $102.63 \mathrm{ppm}$ is ${ }^{31} \mathrm{P}$ signal of cBRIDP bound $\mathrm{Pd}$

- A peak at $49.5 \mathrm{ppm}$ is ${ }^{31} \mathrm{P}$ signal of cBRIDP bound $\mathrm{Cu}\left(\mathrm{CH}_{3} \mathrm{CN}\right)_{4} \mathrm{PF}_{6}$

- A peak at $69.6 \mathrm{ppm}$ is ${ }^{31} \mathrm{P}$ signal of metal-bound phosphine immobilized on charcoal surface. This is an active nanocatalyst 


\section{(c) Effect of Pd : Cu ratio on catalyst structure}

(i) Sample preparation. All samples described in Table S15 were heated at $60{ }^{\circ} \mathrm{C}$ under inert atmosphere for 15 minutes.

Table S15. Sample details for the NMR experiments

\begin{tabular}{|c|c|}
\hline Sample ID & Constituents \\
\hline Sample-A & $\begin{array}{c}1.4 \mathrm{mg} \mathrm{Pd}(\mathrm{OAc})_{2}, 2.2 \mathrm{mg} \mathrm{Cu}\left(\mathrm{CH}_{3} \mathrm{CN}\right)_{4} \mathrm{PF}_{6}, 3.2 \mathrm{mg} \text { cBRIDP, } 3 \mathrm{mg} \text { charcoal in } 0.5 \mathrm{~mL} \text { dry THF } \\
(\mathrm{Pd}: \mathrm{Cu}: \mathrm{cBRIDP}=2: 2: 3)\end{array}$ \\
\hline Sample-B & $\begin{array}{c}1.4 \mathrm{mg} \mathrm{Pd}(\mathrm{OAc})_{2}, 1.1 \mathrm{mg} \mathrm{Cu}\left(\mathrm{CH}_{3} \mathrm{CN}\right)_{4} \mathrm{PF}_{6}, 3.2 \mathrm{mg} \text { cBRIDP, } 3 \mathrm{mg} \text { charcoal in } 0.5 \mathrm{~mL} \text { dry THF } \\
(\mathrm{Pd}: \mathrm{Cu}: \mathrm{cBRIDP}=2: 1: 3)\end{array}$ \\
\hline Sample-C & $\begin{array}{c}0.67 \mathrm{mg} \mathrm{Pd}(\mathrm{OAc})_{2}{ }^{*}, 3.3 \mathrm{mg} \mathrm{Cu}\left(\mathrm{CH}_{3} \mathrm{CN}\right)_{4} \mathrm{PF}_{6}, 3.2 \mathrm{mg} \text { cBRIDP, } 3 \mathrm{mg} \text { charcoal in } 0.5 \mathrm{~mL} \text { dry THF } \\
(\mathrm{Pd}: \mathrm{Cu}: \mathrm{cBRIDP}=1: 3: 3)\end{array}$ \\
\hline
\end{tabular}

(ii) NMR experiments. All experiments were carried out in Varian Innova $400 \mathrm{MHz}$ NMR at 25 ${ }^{\circ} \mathrm{C}$. DMSO $\left(\mathrm{d}_{6}\right)$ as NMR solvent and $\mathrm{PPh}_{3}$ as internal standard were used in each experiment. From above stock solutions, $0.1 \mathrm{~mL}$ analyte was withdrawn and further diluted with $0.4 \mathrm{~mL} \mathrm{DMSO}\left(\mathrm{d}_{6}\right)$. Resulting sample was analyzed by NMR spectroscopy as illustrated in Figure S6.

(Note: The internal standard was prepared in a capillary tube by dissolving $P P_{3}$ in DMSO(d6) in a capillary tube, and tip of capillary tube was permanently sealed)

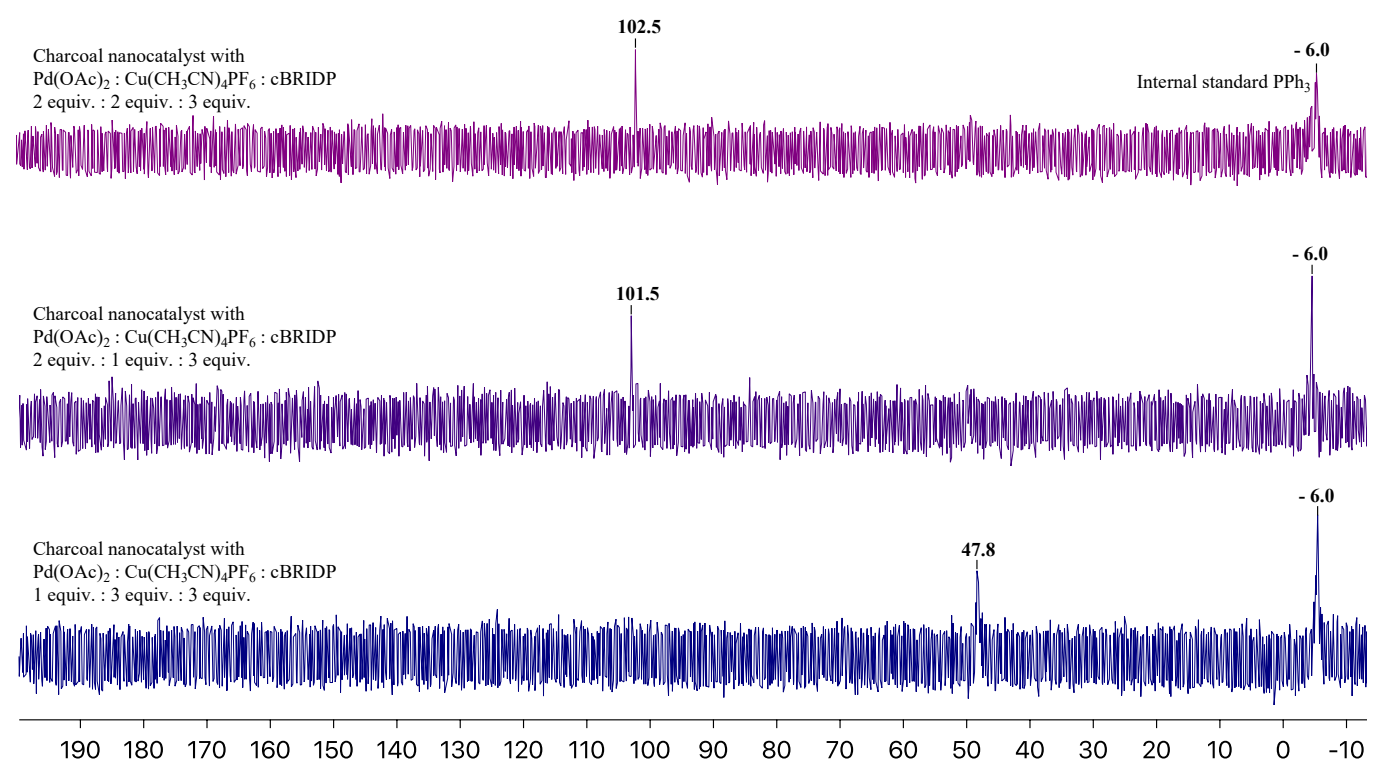

Figure S6. 31P NMR studies on the catalyst structure up varying the $\mathrm{Pd} / \mathrm{Cu}$ ratio. 


\section{(d) Interaction of aniline with catalyst}

(i) Sample preparation. Sample A, B \& C described in Table S16 were heated at $60{ }^{\circ} \mathrm{C}$ under inert atmosphere for $1 \mathrm{~h}$.

Table S16. Sample details for the NMR experiments

\begin{tabular}{c|c}
\hline Sample ID & Constituents \\
\hline Sample-A & $9 \mathrm{mg}$ charcoal nanocatalyst \\
Sample-B & $10 \mathrm{mg} p$-toluidine, $9 \mathrm{mg}$ charcoal nanocatalyst in $0.5 \mathrm{~mL}$ dry THF \\
Sample-C & $1 \mathrm{mg} p$-toluidine, $9 \mathrm{mg}$ charcoal nanocatalyst in $0.5 \mathrm{~mL}$ dry $\mathrm{THF}\left(\right.$ Ar- $\mathrm{NH}_{2}:$ nanocatalyst $\left.=1: 1\right)$ \\
\hline
\end{tabular}

(ii) NMR experiments. All experiments were carried out in Varian Innova $400 \mathrm{MHz}$ NMR at 25 ${ }^{\circ} \mathrm{C}$. DMSO $\left(\mathrm{d}_{6}\right)$ as NMR solvent and $\mathrm{PPh}_{3}$ as internal standard were used in each experiment. From above stock solutions, $0.2 \mathrm{~mL}$ analyte was withdrawn and further diluted with $0.4 \mathrm{~mL} \mathrm{DMSO}\left(\mathrm{d}_{6}\right)$. Resulting sample was analyzed by NMR spectroscopy as illustrated in Figure S7.

(Note: The internal standard was prepared in a capillary tube by dissolving $\mathrm{PPh}_{3}$ in DMSO(d6) in a capillary tube, and tip of capillary tube was permanently sealed)

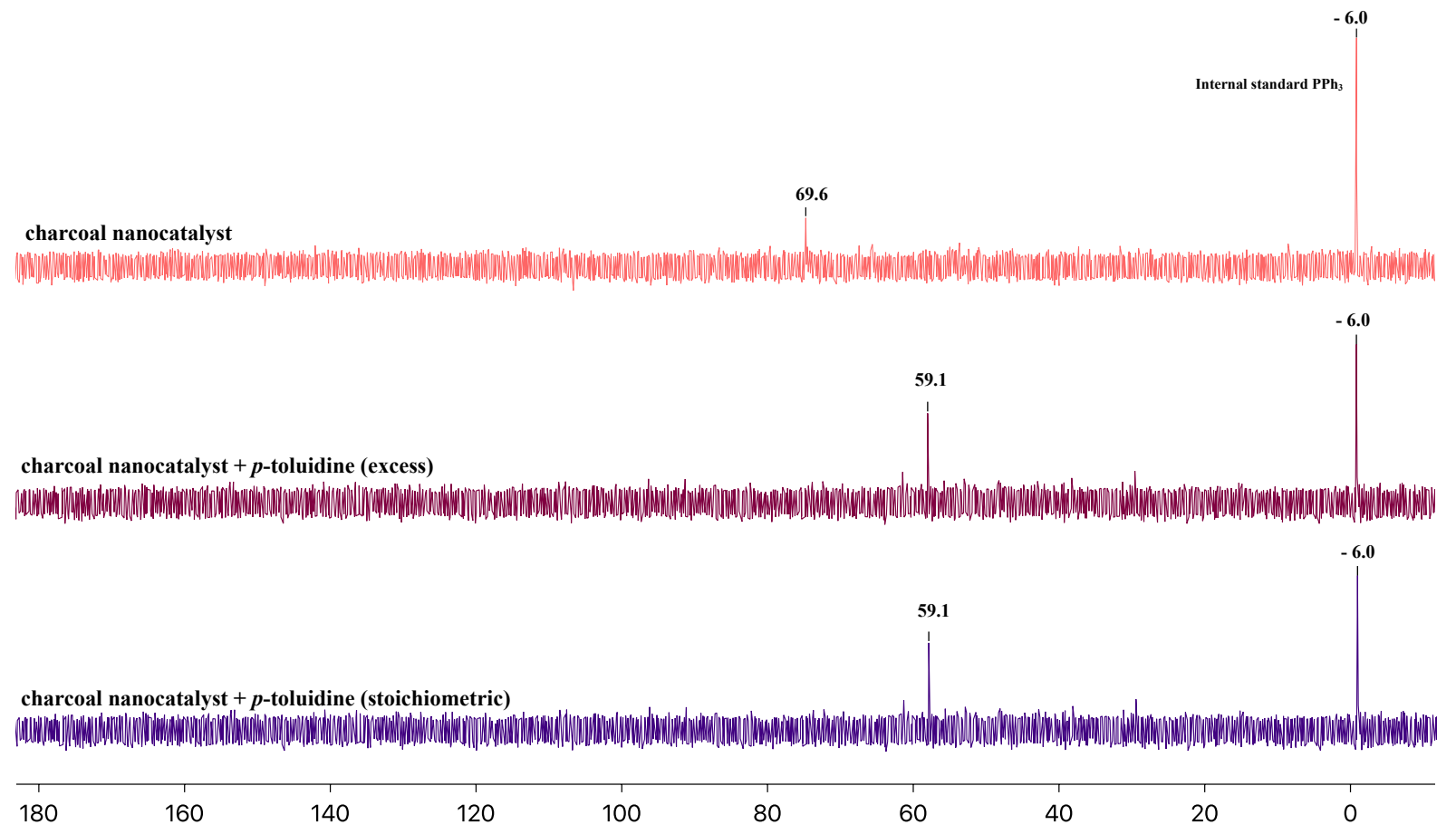

Figure S7. ${ }^{31} \mathrm{P}$ NMR studies on the interaction of catalyst with $p$-toluidine. 
(e) Fresh versus recycled nanocatalyst. Fresh and recycled catalyst was analyzed by ${ }^{31} \mathrm{P}$ NMR spectroscopy (Figure S8).

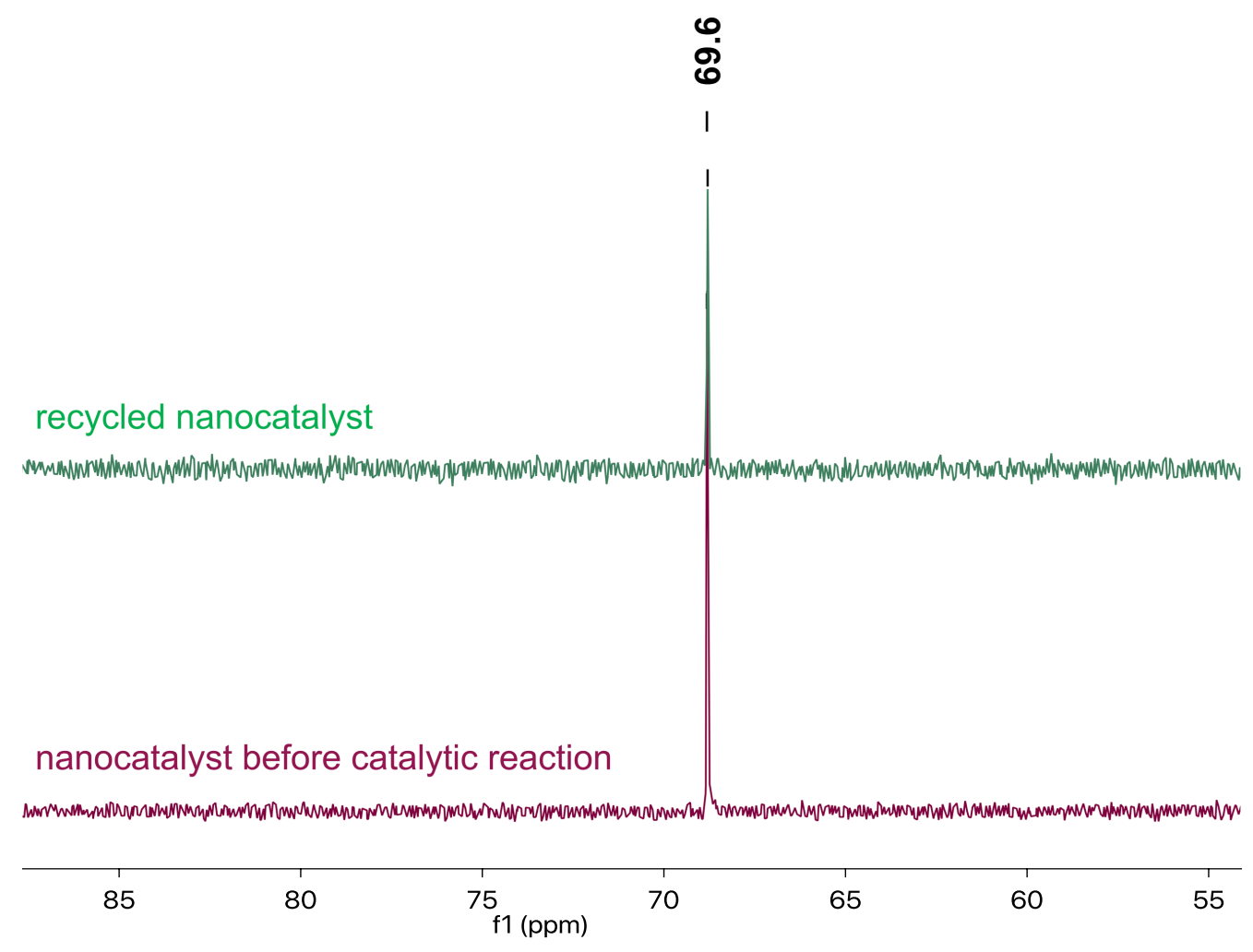

Figure S8. ${ }^{31} \mathrm{P}$ NMR studies on the stability of the recycled catalyst.

17.2. HRTEM analysis. In a $2 \mathrm{~mL}$ oven-dried reaction vial containing a PTFE-coated stir bar, palladium(II) acetate $(6.7 \mathrm{mg}, 0.028 \mathrm{mmol})$, tetrakis(acetonitrile)copper(I) hexafluorophosphate (22 mg, $0.057 \mathrm{mmol}$ ), and cBRIDP (31.7 mg, $0.084 \mathrm{mmol}$ ) were added. Reaction vial was closed with a cap containing PTFE septum cover. Reaction vials was evacuated and then backfilled with argon. This process of evacuation and backfilling with argon was repeated for three times. Via syringe, $1.0 \mathrm{~mL}$ dry THF was added to the reaction mixture. Reaction mixture was gently heated with a heat-gun for a minute. During heating, mixture color was changed from yellow to red. Using pre-heated oil bath, reaction mixture was further heated at $60^{\circ} \mathrm{C}$ for $15 \mathrm{~min}$. Reaction mixture was allowed to cool to rt. Reaction vial was opened under argon atmosphere and activated charcoal (30 mg) was added to it. Reaction vial was closed with a cap and the mixture was further stirred at $60^{\circ} \mathrm{C}$ for $30 \mathrm{~min}$. Finally, volatiles were removed under reduced pressure and resulting solid 
material was dried under vacuum for overnight to obtain a free flowing nanopowder (92 $\mathrm{mg})$. The resulting material was used analyzed by HRTEM (Figure S9).
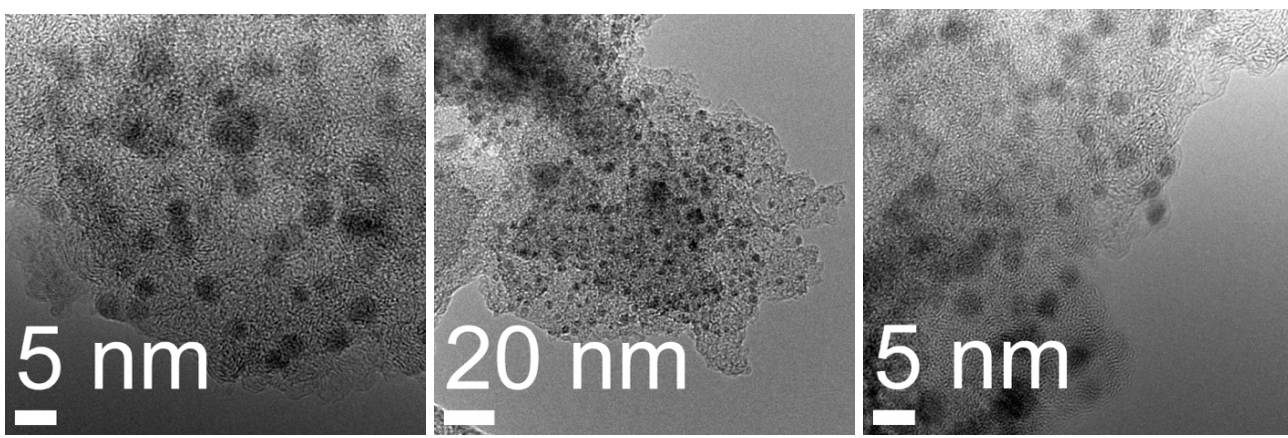

Figure S9. HRTEM images of nanocatalyst.

The average particle size was calculated from these images and histogram was obtained for the size distribution (Figure S10).

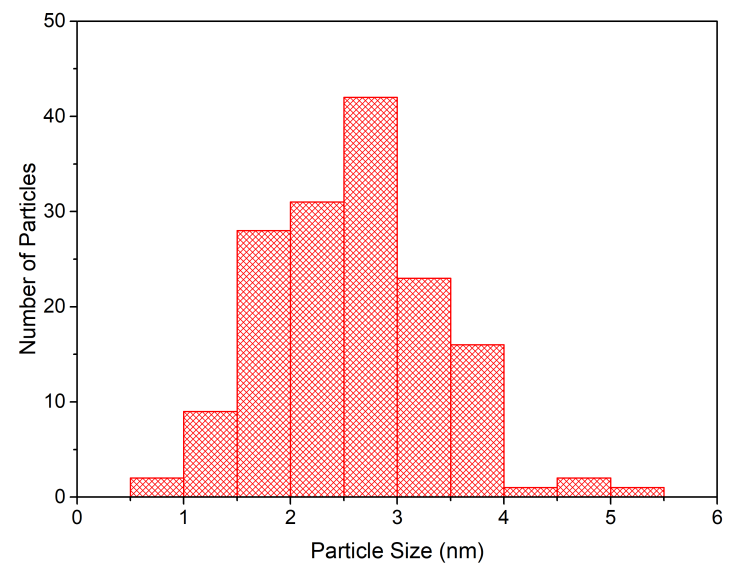

Figure S10. Particle size distribution of the nanocatalyst.

17.3. SEM analysis of surfactant bound nanocatalyst. $25 \mathrm{mg}$ nanocatalyst was dissolved in 10 wt \% aqueous PS-750-M (10 mL) and resulting material was analyzed by SEM (Figure S11).
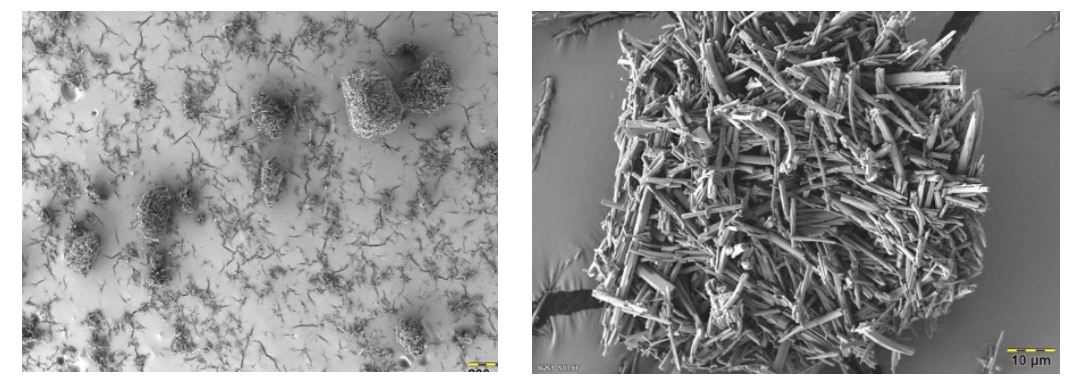

Figure S11. SEM analysis of the nanocatalyst. 


\subsection{TGA of nanocatalyst.}

Sample prepared for HRTEM analysis in section 16.2 was used for TGA analysis (Figure S12).

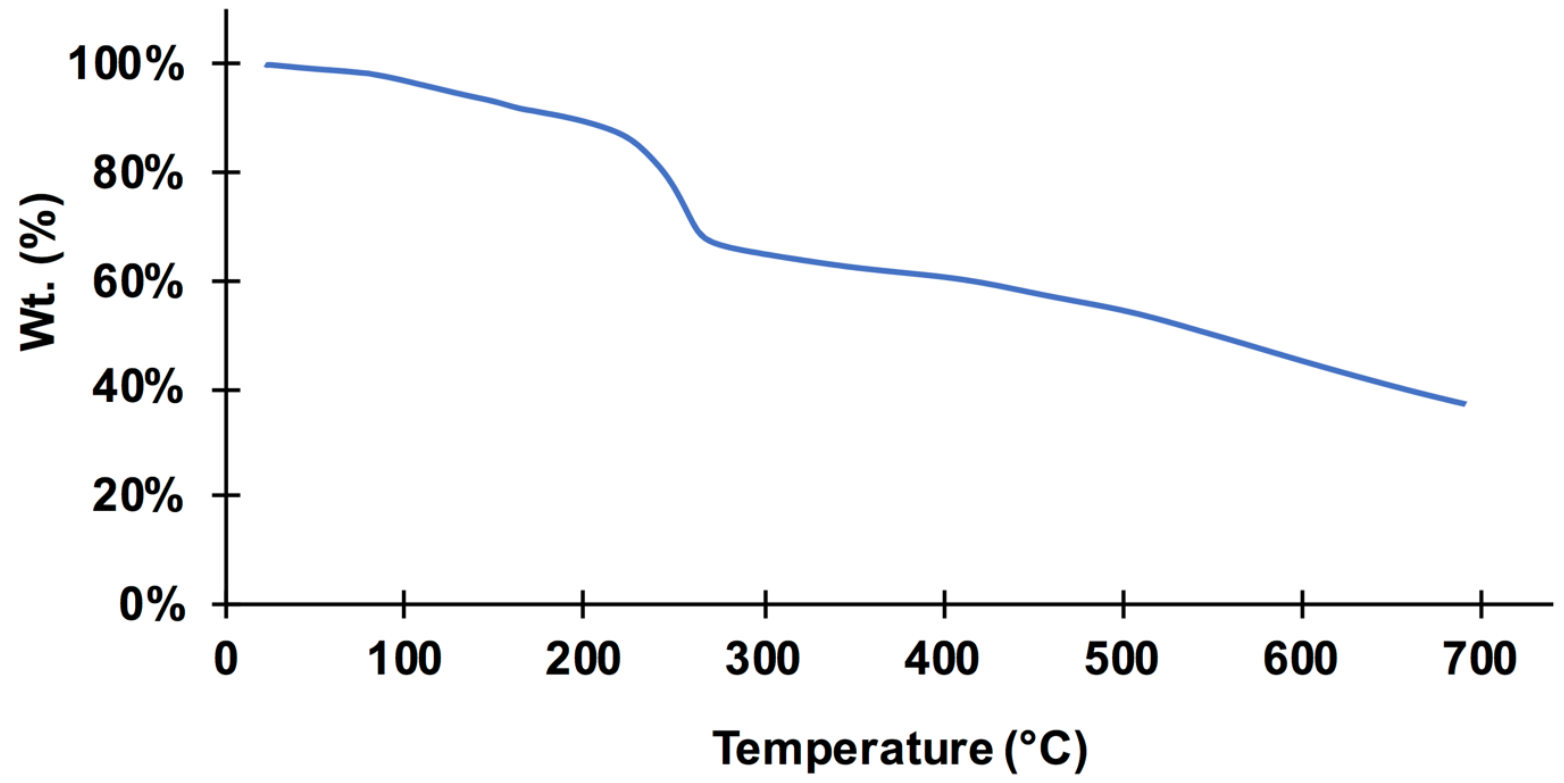

Figure S12. TGA analysis of the nanocatalyst. 


\subsection{XPS analysis of catalyst.}
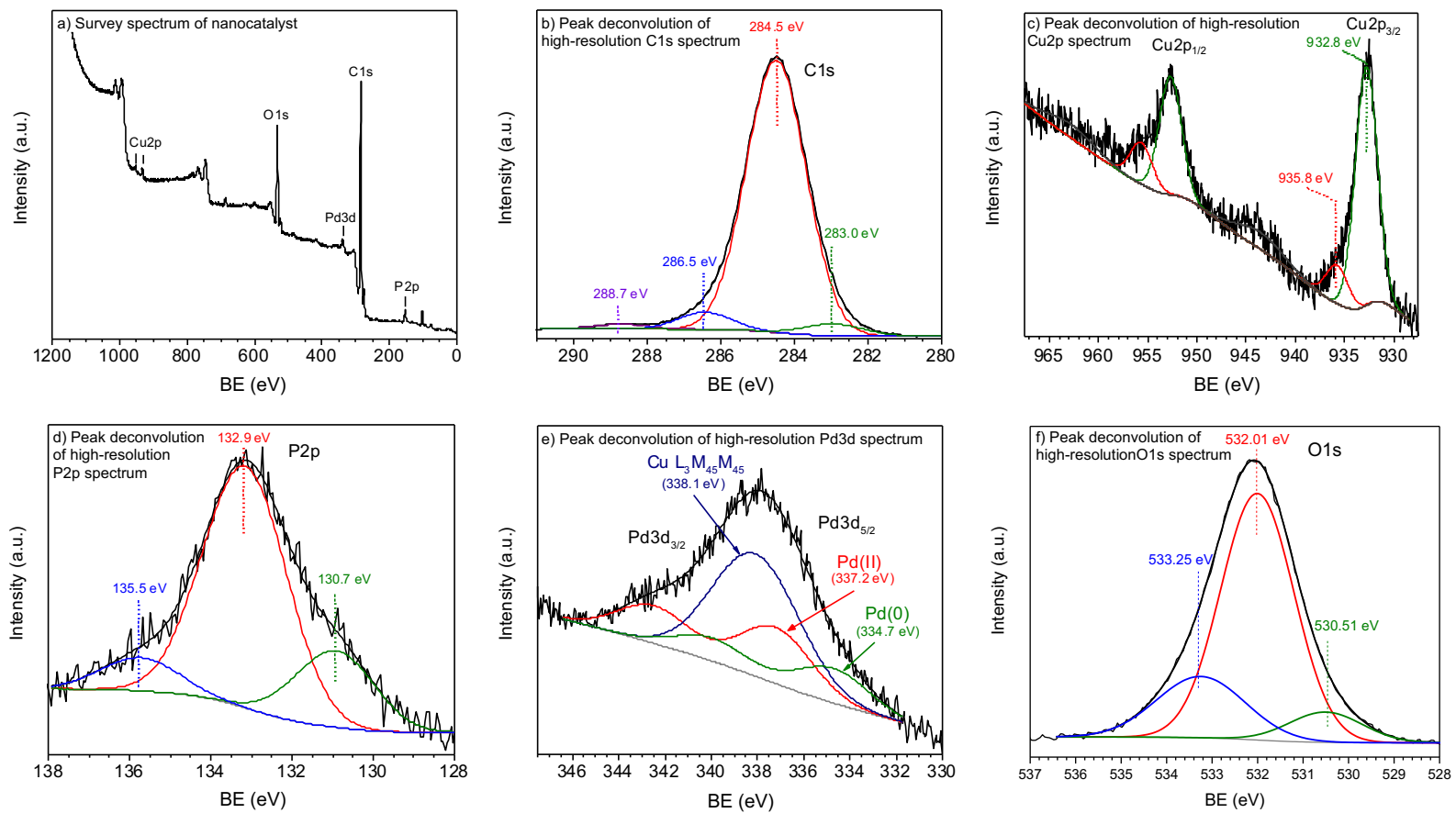

Figure S13. XPS analysis of the nanocatalyst, a) Survey spectrum of nanocatalyst, b) Peak deconvolution of high-resolution $\mathrm{C} 1$ s spectrum, c) Peak deconvolution of high-resolution $\mathrm{Cu} 2 \mathrm{p}$ spectrum, d) Peak deconvolution of high-resolution P2p spectrum, e) Peak deconvolution of highresolution Pd3d spectrum, f) Peak deconvolution of high-resolution O1s spectrum.

Table S17. Details of XPS analysis.

\begin{tabular}{c|ccc}
\hline ASF & XPS line & Area & \% Atomic Composition \\
\hline 5.321 & $\mathrm{Cu} 2 \mathrm{p}$ & 7552 & 0.5612315 \\
5.356 & $\mathrm{Pd} 3 \mathrm{~d}$ & 1979 & 0.146109529 \\
0.296 & $\mathrm{C} 1 \mathrm{~s}$ & 61425 & 82.05910394 \\
0.486 & $\mathrm{P} 2 \mathrm{p}$ & 712 & 0.579318024 \\
0.711 & $\mathrm{O} 1 \mathrm{~s}$ & 29944.773 & 16.654237 \\
\hline
\end{tabular}

X-ray photoelectron spectroscopy (XPS) measurements were conducted using a VG Scientific MultiLab 3000 ultra-high vacuum surface analysis system, operating at the base pressure in the $10^{-9}$ Torr range and equipped with dual-anode $(\mathrm{Mg} / \mathrm{Al}) \mathrm{X}$-ray source and CLAM4 hemispherical electron energy analyzer. For this study, non-monochromatized Al K $\alpha$ X-ray beam $(\mathrm{h} v \approx 1486.6$ $\mathrm{eV}$ ) was used as the source. XPS spectra were collected at an electron emission angle of $54.7^{\circ}$ 
relative to the surface normal. A low-resolution survey spectrum from 1200 to $0 \mathrm{eV}$ was collected using Pass energy of $100 \mathrm{eV}$ to identify all elements. Additionally, high-resolution spectra of $\mathrm{C} 1 \mathrm{~s}$, $\mathrm{Pd} 3 \mathrm{~d}, \mathrm{Cu} 2 \mathrm{p}$, and $\mathrm{O} 1 \mathrm{~s}$ were collected at Pass energy of $20 \mathrm{eV}$, for the detailed binding energy (BE) analysis. The adventitious $\mathrm{C} 1 \mathrm{~s}, \mathrm{C}-\mathrm{C}$ peak at $284.5 \mathrm{eV}$, was used for the $\mathrm{BE}$ calibration.

Fig. S13a shows the survey spectrum of nanocatalyst. Fig. S13b shows the deconvolution of highresolution $\mathrm{C} 1 \mathrm{~s}$ spectrum. The spectrum confirmed the presence of $\mathrm{Cu}, \mathrm{O}, \mathrm{Pd}, \mathrm{C}$, and $\mathrm{P}$. The peak deconvolution of the high-resolution spectrum of $\mathrm{Cu} 2 \mathrm{p}$ (Fig. S13c) yields two species of $\mathrm{Cu}$, one with the $\mathrm{Cu} 2 \mathrm{p}_{3 / 2}$ peak at the $\mathrm{BE}$ of $932.8 \mathrm{eV}$ and the other at $935.8 \mathrm{eV}$. These values correspond to the $\mathrm{Cu}(\mathrm{I})$ and $\mathrm{Cu}(\mathrm{II})$, respectively. Fig. S13d, presents the peak deconvolution of the highresolution spectrum of $\mathrm{P} 2 \mathrm{p}$, which indicates three species of $\mathrm{P}$, corresponding to the $\mathrm{BE}$ values of P2p peak equal $132.9 \mathrm{eV}, 130.7 \mathrm{eV}$ and $135.5 \mathrm{eV}$. The peak deconvolution of the high-resolution Pd3d spectrum (Fig. S13e) indicates multiple oxidation states. The obtained BE values of 337.2 $\mathrm{eV}$ and $334.7 \mathrm{eV}$ represent $\mathrm{Pd}(\mathrm{O})$ and $\mathrm{Pd}(\mathrm{II})$ species, respectively. The peak deconvolution of the high-resolution spectrum of O1s (Fig. S13f) yields BE values, $533.5 \mathrm{eV}, 532.01$ and $530.51 \mathrm{eV}$ which represent ethers/oxides.

The $\%$ atomic composition is described in Table S17. 


\section{ANALYTICAL DATA}

\section{1-(3,5-Bis(trifluoromethyl)phenyl)-5-methoxy-1H-indole}

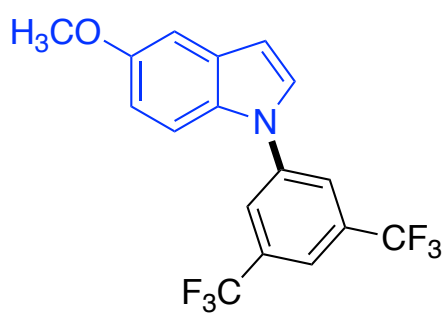

White solid, yield $96.8 \mathrm{mg}(90 \%), \mathrm{mp}=79{ }^{\circ} \mathrm{C}, \mathrm{R}_{f} 0.4$ (4:1, hexanes/ethyl acetate). ${ }^{1} \mathrm{H}$ NMR $(500$ $\left.\mathrm{MHz}, \mathrm{CDCl}_{3}\right): \delta 7.96(\mathrm{~s}, 2 \mathrm{H}), 7.82(\mathrm{~s}, 1 \mathrm{H}), 7.44(\mathrm{~d}, J=9.5 \mathrm{~Hz}, 1 \mathrm{H}), 7.33(\mathrm{~d}, J=3.5 \mathrm{~Hz}, 1 \mathrm{H}), 7.16$ $(\mathrm{d}, J=2.5 \mathrm{~Hz}, 1 \mathrm{H}), 6.95(\mathrm{dd}, J=2.5 \mathrm{~Hz}, 9.5 \mathrm{~Hz}, 1 \mathrm{H}), 6.70(\mathrm{dd}, J=0.5 \mathrm{~Hz}, 3 \mathrm{~Hz}, 1 \mathrm{H}), 3.89(\mathrm{~s}, 3 \mathrm{H})$; ${ }^{13} \mathrm{C} \mathrm{NMR}\left(125 \mathrm{MHz}, \mathrm{CDCl}_{3}\right): \delta 155.6,141.7,133.7(\mathrm{q}, J=26.97 \mathrm{~Hz}) 130.8,130.8,127.9,123.7$, $123.2(\mathrm{q}, J=271 \mathrm{~Hz}), 119.6,113.7,111.0,106.0,103.7,56.2 ;{ }^{19} \mathrm{~F} \mathrm{NMR}\left(376 \mathrm{MHz}, \mathrm{CDCl}_{3}\right):-63.00$ ppm. IR $\vee\left(\mathrm{cm}^{-1}\right)$ 2933(m), 2200(w), $1406(\mathrm{~m})$. HRMS $\left[\mathrm{C}_{17} \mathrm{H}_{11} \mathrm{~F}_{6} \mathrm{NO}+\mathrm{H}^{+}\right]$calcd $=360.0818$, found $\mathrm{m} / \mathrm{z}=360.0818$.

\section{0-(p-Tolyl)-10H-phenothiazine ${ }^{1}$}

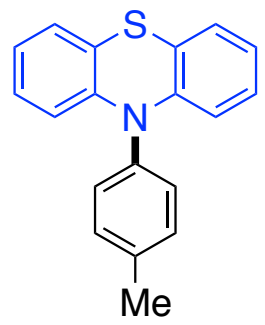

Yellow solid, yield $62.5 \mathrm{mg}(72 \%), \mathrm{R}_{f} 0.4$ (4:1, hexanes/ethyl acetate). ${ }^{1} \mathrm{H}$ NMR (500 MHz, $\left.\mathrm{CDCl}_{3}\right): \delta 7.40(\mathrm{~d}, J=8.5 \mathrm{~Hz}, 2 \mathrm{H}), 7.28(\mathrm{~s}, 1 \mathrm{H}), 6.99(\mathrm{dd}, J=8 \mathrm{~Hz}, 2 \mathrm{~Hz}, 2 \mathrm{H}), 6.82-6.77(\mathrm{~m}, 5 \mathrm{H})$, 6.19(dd, $J=8 \mathrm{~Hz}, 1.5 \mathrm{~Hz}, 2 \mathrm{H}), 2.46$ (s, 3H).

\section{2-(1H-Indol-1-yl)quinoline ${ }^{2}$}

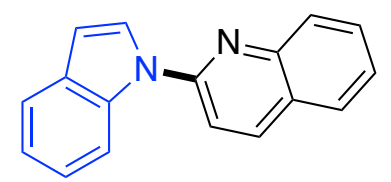

Yellow oil, yield $47.5 \mathrm{mg}$ (65\%), $\mathrm{R}_{f} 0.4$ (3:2, hexanes/ethyl acetate). ${ }^{1} \mathrm{H}$ NMR (500 MHz, $\left.\mathrm{CDCl}_{3}\right)$ : $\delta 8.59(\mathrm{~d}, J=8.5 \mathrm{~Hz}, 1 \mathrm{H}), 8.27$ (d, $J=9 \mathrm{~Hz}, 1 \mathrm{H}), 8.10(\mathrm{~d}, J=8.5 \mathrm{~Hz}, 1 \mathrm{H}), 7.85-7.81(\mathrm{~m}, 2 \mathrm{H})$, 
$7.75(\mathrm{t}, J=7 \mathrm{~Hz}, 1 \mathrm{H}), 7.70-7.66(\mathrm{~m}, 2 \mathrm{H}), 7.52(\mathrm{t}, J=8.5,1 \mathrm{H}), 7.36(\mathrm{t}, J=7 \mathrm{~Hz}, 1 \mathrm{H}), 7.24(\mathrm{~d}, J=$ $7 \mathrm{~Hz}, 1 \mathrm{H}), 6.78(\mathrm{~d}, J=3.5 \mathrm{~Hz}, 1 \mathrm{H})$.

\section{1-(4-Methoxyphenyl)-1H-indole ${ }^{3}$}

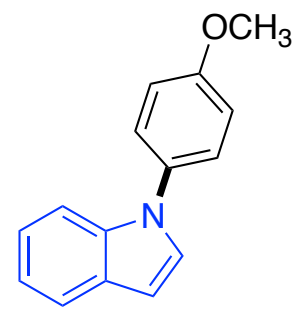

White solid, yield $57.5 \mathrm{mg}(86 \%), \mathrm{R}_{f} 0.4$ (9:1, hexanes/ethyl acetate). ${ }^{1} \mathrm{H} \mathrm{NMR}\left(500 \mathrm{MHz}, \mathrm{CDCl}_{3}\right)$ : $\delta 7.68(\mathrm{~d}, J=7.5 \mathrm{~Hz}, 1 \mathrm{H}), 7.45(\mathrm{~d}, J=8.5 \mathrm{~Hz}, 1 \mathrm{H}), 7.41(\mathrm{~d}, J=8.5 \mathrm{~Hz}, 2 \mathrm{H}), 7.28$ (d, $J=3 \mathrm{~Hz}$, $\mathrm{s} 1 \mathrm{H}), 7.2(\mathrm{t}, J=7 \mathrm{~Hz}, 1 \mathrm{H}), 7.15(\mathrm{t}, J=7 \mathrm{~Hz}, 1 \mathrm{H}), 7.04(\mathrm{~d}, J=9 \mathrm{~Hz}, 2 \mathrm{H}), 6.65(\mathrm{~d}, J=3 \mathrm{~Hz}, 1 \mathrm{H})$, $3.88(\mathrm{~s}, 3 \mathrm{H})$.

\section{4-(Naphthalen-1-yl)morpholine ${ }^{4}$}<smiles>c1ccc2c(N3CCOCC3)cccc2c1</smiles>

Yellow liquid, yield $53.0 \mathrm{mg}(83 \%), \mathrm{R}_{f} 0.4$ (19:1, hexanes/ethyl acetate). ${ }^{1} \mathrm{H}$ NMR (500 MHz, $\left.\mathrm{CDCl}_{3}\right): \delta 8.22(\mathrm{dd}, J=2 \mathrm{~Hz}, 7 \mathrm{~Hz}, 1 \mathrm{H}), 7.84(\mathrm{dd}, J=1 \mathrm{H}, 1 \mathrm{H}), 7.57(\mathrm{~d}, J=8.5 \mathrm{~Hz}, 1 \mathrm{H}), 7.50-$ $7.45(\mathrm{~m}, 2 \mathrm{H}), 7.43(\mathrm{t}, J=7.5 \mathrm{~Hz}, 1 \mathrm{H}), 7.10(\mathrm{~d}, J=8 \mathrm{~Hz}, 1 \mathrm{H}), 3.99(\mathrm{t}, J=4.5 \mathrm{~Hz}, 4 \mathrm{H}), 3.13(\mathrm{t}, J=$ $4 \mathrm{~Hz}, 4 \mathrm{H})$.

\section{1-(4-Chlorophenyl)-5-methoxy-1H-indole ${ }^{5}$}

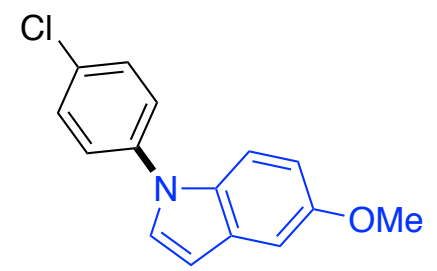

Viscous oil, yield $65.0 \mathrm{mg}(84 \%), \mathrm{R}_{f} 0.3$ (19:1, hexanes/ethyl acetate). ${ }^{1} \mathrm{H}$ NMR (400 MHz, $\left.\mathrm{CDCl}_{3}\right): \delta 7.54-7.37(\mathrm{~m}, 5 \mathrm{H}), 7.27(\mathrm{~d}, J=3.2 \mathrm{~Hz}, 1 \mathrm{H}), 7.14(\mathrm{~d}, J=2.4 \mathrm{~Hz}, 1 \mathrm{H}), 6.89(\mathrm{dd}, J=2.4$ 
$\mathrm{Hz}, J=8.8 \mathrm{~Hz}, 1 \mathrm{H}), 6.61(\mathrm{~d}, J=2.8 \mathrm{~Hz}, 1 \mathrm{H}), 7.10(\mathrm{~d}, J=8 \mathrm{~Hz}, 1 \mathrm{H}), 3.99(\mathrm{t}, J=4.5 \mathrm{~Hz}, 4 \mathrm{H}), 3.13$ (t, $J=4 \mathrm{~Hz}, 4 \mathrm{H}), 3.98(\mathrm{~s}, 3 \mathrm{H})$.

\section{4-(1H-Indol-1-yl)benzonitrile ${ }^{6}$}

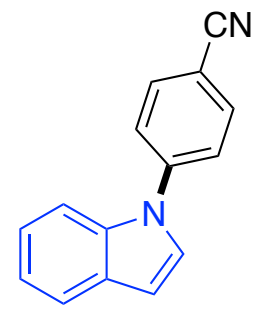

White solid, yield $52.1 \mathrm{mg}(82 \%), \mathrm{R}_{f} 0.3$ (9:1, hexanes/ethyl acetate). ${ }^{1} \mathrm{H} \mathrm{NMR}\left(500 \mathrm{MHz}, \mathrm{CDCl}_{3}\right)$ : $\delta 7.81(\mathrm{dd}, J=1.5 \mathrm{~Hz}, 6.5 \mathrm{~Hz}, 2 \mathrm{H}), 7.71(\mathrm{~d}, J=8 \mathrm{~Hz}, 1 \mathrm{H}), 7.64(\mathrm{dd}, J=2.5 \mathrm{~Hz}, 7 \mathrm{~Hz}, 2 \mathrm{H}), 7.62$ (d, $J=8.5 \mathrm{~Hz}, 1 \mathrm{H}), 7.35(\mathrm{~d}, J=3 \mathrm{~Hz}, 1 \mathrm{H}), 7.33-7.27(\mathrm{~m}, 1 \mathrm{H}), 7.22-7.25(\mathrm{~m}, 1 \mathrm{H}), 6.76(\mathrm{~d}, J=3.5$ $\mathrm{Hz}, 1 \mathrm{H})$.

\section{$N-\left(p\right.$-Tolyl)naphthalen-1-amine ${ }^{7}$}

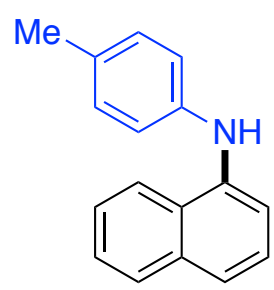

Pale yellow Oil, yield $64.1 \mathrm{mg}(92 \%), \mathrm{R}_{f} 0.4$ (9:1, hexanes/ethyl acetate). ${ }^{1} \mathrm{H}$ NMR (500 MHz, $\left.\mathrm{CDCl}_{3}\right): \delta 8.02(\mathrm{~d}, J=8 \mathrm{~Hz}, 1 \mathrm{H}), 7.87(\mathrm{~d}, J=9 \mathrm{~Hz}, 1 \mathrm{H}), 7.53-7.46(\mathrm{~m}, 3 \mathrm{H}), 7.38(\mathrm{t}, J=8 \mathrm{~Hz}, 1 \mathrm{H})$, $7.29(\mathrm{~d}, J=7 \mathrm{~Hz}, 1 \mathrm{H}), 7.10(\mathrm{~d}, J=8.5 \mathrm{~Hz}, 2 \mathrm{H}), 6.97(\mathrm{~d}, J=8.5,2 \mathrm{H}), 2.33(\mathrm{~s}, 3 \mathrm{H})$.

\section{1-(6-Methoxypyridin-2-yl)-1H-indole ${ }^{8}$}

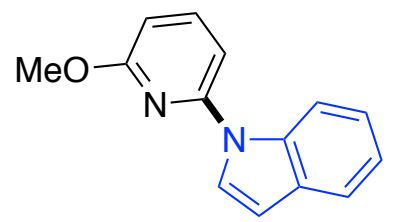

Colorless viscous oil, yield $59.2 \mathrm{mg}(88 \%), \mathrm{R}_{f} 0.3$ (3:1, hexanes/ethyl acetate). ${ }^{1} \mathrm{H}$ NMR (400 $\left.\mathrm{MHz}_{\mathrm{CDCl}}\right): \delta 7.92(\mathrm{~d}, J=8.4 \mathrm{~Hz}, 1 \mathrm{H}), 7.28-7.34(\mathrm{~m}, 3 \mathrm{H}), 6.93(\mathrm{t}, J=7.2 \mathrm{~Hz}, 1 \mathrm{H}), 6.85(\mathrm{t}, J=$ $7.2 \mathrm{~Hz}, 1 \mathrm{H}), 6.63$ (d, $J=7.6 \mathrm{~Hz}, 1 \mathrm{H}), 6.33$ (d, $J=2.8 \mathrm{~Hz}, 1 \mathrm{H}), 6.24$ (d, $J=8.4 \mathrm{~Hz}, 4 \mathrm{H}), 3.67$ (s, $3 \mathrm{H})$. 
10-(3,5-Bis(trifluoromethyl)phenyl)-10H-phenothiazine ${ }^{9}$<smiles>FC(F)(F)c1cc(N2c3ccccc3Sc3ccccc32)cc(C(F)(F)F)c1</smiles>

Yellow solid, yield $102.3 \mathrm{mg}(83 \%), \mathrm{R}_{f} 0.3$ (9:1, hexanes/ethyl acetate). ${ }^{1} \mathrm{H}$ NMR (400 MHz, $\left.\mathrm{CDCl}_{3}\right): \delta 7.59(\mathrm{~s}, 1 \mathrm{H}), 7.55(\mathrm{~s}, 2 \mathrm{H}), 7.37(\mathrm{dd}, J=1.2 \mathrm{~Hz}, 8 \mathrm{~Hz}, 2 \mathrm{H}), 7.25-7.12(\mathrm{~m}, 2 \mathrm{H}), 7.16-$ $7.12(\mathrm{~m}, 2 \mathrm{H}), 6.96(\mathrm{~d}, J=7.6 \mathrm{~Hz}, 2 \mathrm{H}) ;{ }^{19} \mathrm{~F} \mathrm{NMR}\left(376 \mathrm{MHz}, \mathrm{CDCl}_{3}\right)-62.99 \mathrm{ppm}$.

\section{4-Methoxy- $N$-(p-tolyl)aniline ${ }^{10}$}

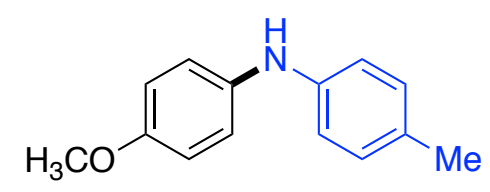

White solid, yield $60.7 \mathrm{mg}(95 \%), \mathrm{R}_{f} 0.6$ (4:1, hexanes/ethyl acetate). ${ }^{1} \mathrm{H} \mathrm{NMR}\left(500 \mathrm{MHz}, \mathrm{CDCl}_{3}\right)$ :

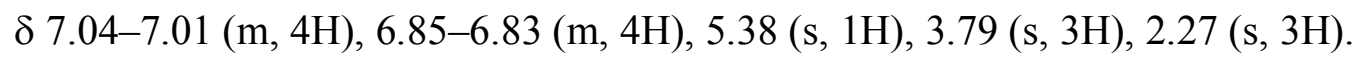

\section{$N$-(p-Tolyl)quinolin-2-amine ${ }^{11}$}

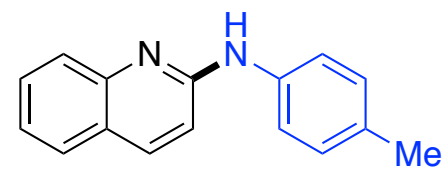

Off-white solid, yield $50.6 \mathrm{mg}$ (72\%), $\mathrm{R}_{f} 0.3$ (4:1, hexanes/ethyl acetate). ${ }^{1} \mathrm{H}$ NMR (500 MHz, $\left.\mathrm{CDCl}_{3}\right): \delta 7.90(\mathrm{~d}, J=8.5 \mathrm{~Hz}, 1 \mathrm{H}), 7.75(\mathrm{~d}, J=8.5 \mathrm{~Hz}, 1 \mathrm{H}), 7.63(\mathrm{~d}, J=8 \mathrm{~Hz}, 1 \mathrm{H}), 7.59-7.56(\mathrm{~m}$, $1 \mathrm{H}), 7.41(\mathrm{~d}, J=8.5 \mathrm{~Hz}, 1 \mathrm{H}), 7.28(\mathrm{~d}, J=8 \mathrm{~Hz}, 1 \mathrm{H}), 7.18(\mathrm{~d}, J=8.5 \mathrm{~Hz}, 1 \mathrm{H}), 6.96(\mathrm{~d}, J=9.5 \mathrm{~Hz}$, 1H), 2.36 (s, 3H).

$N$-(p-tolyl)pyrimidin-2-amine ${ }^{12}$<smiles>Cc1ccc(Nc2ncccn2)cc1</smiles> 
White solid, yield $50.6 \mathrm{mg}$ (92\%), $\mathrm{R}_{f} 0.3$ (4:1, hexanes/ethyl acetate). ${ }^{1} \mathrm{H} \mathrm{NMR}\left(500 \mathrm{MHz}, \mathrm{CDCl}_{3}\right)$ : $\delta 8.39(\mathrm{~d}, J=5 \mathrm{~Hz}, 2 \mathrm{H}), 7.47$ (d, $J=8.5 \mathrm{~Hz}, 2 \mathrm{H}), 7.14(\mathrm{~d}, J=8.5 \mathrm{~Hz}, 2 \mathrm{H}), 7.09(\mathrm{~s}, 1 \mathrm{H}), 6.68(\mathrm{t}, J$ $=5 \mathrm{~Hz}, 1 \mathrm{H}), 2.32(\mathrm{~s}, 3 \mathrm{H})$.

\section{$N$-(p-tolyl)benzo[b]thiophen-5-amine}

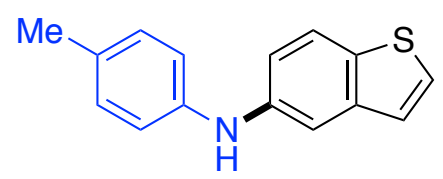

Yellow Oil, yield $57.4 \mathrm{mg}(80 \%), \mathrm{R}_{f} 0.3$ (4:1, hexanes/ethyl acetate). ${ }^{1} \mathrm{H}$ NMR (500 MHz, $\left.\mathrm{CDCl}_{3}\right)$ : $\delta 7.67(\mathrm{~d}, J=8.5 \mathrm{~Hz}, 1 \mathrm{H}), 7.52(\mathrm{~s}, 1 \mathrm{H}), 7.22(\mathrm{dd}, J=5.5 \mathrm{~Hz}, 7 \mathrm{~Hz}, 2 \mathrm{H}), 7.12(\mathrm{~d}, J=8 \mathrm{~Hz}, 2), 7.03$ $(\mathrm{d}, J=7.5 \mathrm{~Hz}, 3 \mathrm{H}), 2.33(\mathrm{~s}, 3 \mathrm{H}) ;{ }^{13} \mathrm{C} \mathrm{NMR}\left(125 \mathrm{MHz}, \mathrm{CDCl}_{3}\right) \delta 141.7,141.0,134.25,131.59$, 130.4, 124.6, 124.00, 123.8, 119.40, 117.1, 109.6, 21.2. IR v ( $\left.\mathrm{cm}^{-1}\right) 348(\mathrm{w}), 2900(\mathrm{~m}), 1550(\mathrm{~s})$. HRMS $\left[\mathrm{C}_{15} \mathrm{H}_{13} \mathrm{NS}+\mathrm{H}^{+}\right]$calcd $=240.0842$, found $\mathrm{m} / \mathrm{z}=240.0842$.

\section{1-(3,5-Bis(trifluoromethyl)benzyl)-4-(3-fluorophenyl)piperazine}

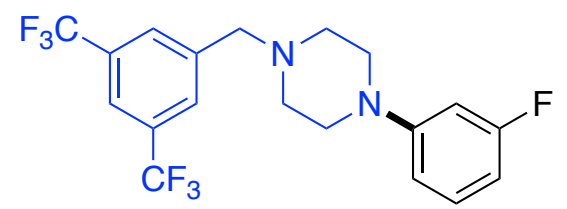

Viscous liquid, yield $86.3 \mathrm{mg}(80 \%), \mathrm{R}_{f} 0.3$ (9:1, hexanes/ethyl acetate). ${ }^{1} \mathrm{H}$ NMR (500 MHz, $\left.\mathrm{CDCl}_{3}\right): \delta 7.84(\mathrm{~s}, 2 \mathrm{H}), 7.79(\mathrm{~s}, 1 \mathrm{H}), 7.27(\mathrm{~m}, 1 \mathrm{H}), 6.67(\mathrm{dd}, J=1.5 \mathrm{~Hz}, 8 \mathrm{~Hz}, 1 \mathrm{H}), 6.61-6.52(\mathrm{~m}$, 2H), 3.23(t, $J=5,4 \mathrm{H}), 2.62(\mathrm{t}, J=5,4 \mathrm{H}) ;{ }^{13} \mathrm{C} \mathrm{NMR}\left(125 \mathrm{MHz}, \mathrm{CDCl}_{3}\right): \delta 165.1,141.4,132.1$, 131.9, 130.7 (q, $J=26.8), 130.4,129.1,121.61,111.5,106.4,106.24,103.2,102.9,62.2,53.8$, 49.0; ${ }^{19} \mathrm{~F}$ NMR (376 MHz, $\left.\mathrm{CDCl}_{3}\right)$ : -63.32, -11.32 ppm. IR $v\left(\mathrm{~cm}^{-1}\right) 1456(\mathrm{~m}), 1245(\mathrm{~s})$. HRMS $\left[\mathrm{C}_{19} \mathrm{H}_{17} \mathrm{~F}_{7} \mathrm{~N}_{2}+\mathrm{H}^{+}\right]$calcd $=407.1353$, found $\mathrm{m} / \mathrm{z}=407.1356$.

\section{4-Chloro-N-(p-tolyl)aniline ${ }^{13}$}<smiles>Cc1ccc(Nc2ccc(Cl)cc2)cc1</smiles> 
White solid, yield $59.5 \mathrm{mg}(91 \%), \mathrm{R}_{f} 0.3$ (19:1, hexanes/ethyl acetate). ${ }^{1} \mathrm{H}$ NMR (500 MHz, $\left.\mathrm{CDCl}_{3}\right): \delta 7.17(\mathrm{~d}, J=8.5 \mathrm{~Hz}, 2 \mathrm{H}), 7.09(\mathrm{~d}, J=8 \mathrm{~Hz}, 2 \mathrm{H}), 6.97(\mathrm{~d}, J=8.5 \mathrm{~Hz}, 2 \mathrm{H}), 6.92(\mathrm{~d}, J=$ $8.5 \mathrm{~Hz}, 2 \mathrm{H}), 2.31(\mathrm{~s}, 3 \mathrm{H})$.

\section{Tert-butyl 5-(p-tolylamino)-1H-indole-1-carboxylate}

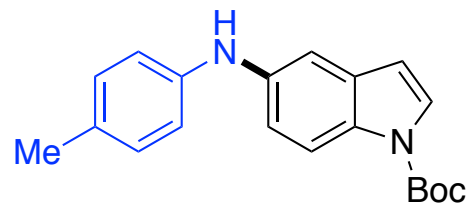

Light brown solid, yield $60.8 \mathrm{mg}(63 \%), \mathrm{MP}=59^{\circ} \mathrm{C}, \mathrm{R}_{f} 0.3$ (9:1, hexanes/ethyl acetate). ${ }^{1} \mathrm{H}$ NMR $\left(500 \mathrm{MHz}, \mathrm{CDCl}_{3}\right): \delta 8.02(\mathrm{~s}, 1 \mathrm{H}), 7.55(\mathrm{~s}, 1 \mathrm{H}), 7.25(\mathrm{~d}, J=3 \mathrm{~Hz}, 1 \mathrm{H}), 7.07(\mathrm{~d}, J=8.5 \mathrm{~Hz}, 2 \mathrm{H})$, $7.03(\mathrm{dd}, J=2 \mathrm{~Hz}, 9 \mathrm{~Hz}, 2 \mathrm{H}), 6.95$ (d, $J=8 \mathrm{~Hz}, 2 \mathrm{H}), 6.45$ (d, $J=3.5 \mathrm{~Hz}, 1 \mathrm{H}), 5.57$ (s, 1H), 2.29 (s, 3H), 1.67 (s, 9H); $;{ }^{13} \mathrm{C}$ NMR (125 MHz, $\left.\mathrm{CDCl}_{3}\right): \delta$ 142.32, 132.28, 130.16, 126.78, 117.72, 117.46, 116.11, 110.33, 107.37, 28.56, 20.95. IR $v\left(\mathrm{~cm}^{-1}\right)$ 3512(broad), 1731(m), $1390(\mathrm{~m})$.

\section{1-(4-(Benzyloxy)phenyl)-1H-indole}

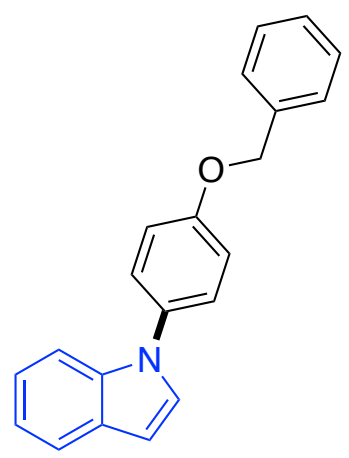

Brown liquid, yield $69 \mathrm{mg}(77 \%), \mathrm{R}_{f} 0.4$ (9:1, hexanes/ethyl acetate). ${ }^{1} \mathrm{H} \mathrm{NMR}\left(400 \mathrm{MHz}, \mathrm{CDCl}_{3}\right)$ : $\delta 7.72(\mathrm{~d}, J=7.6 \mathrm{~Hz}, 1 \mathrm{H}), 7.50(\mathrm{~d}, J=6.8 \mathrm{~Hz}, 3 \mathrm{H}), 7.47-7.39(\mathrm{~m}, 5 \mathrm{H}), 7.31(\mathrm{~d}, J=3.2 \mathrm{~Hz}, 1 \mathrm{H})$, 7.24-7.19 (m, 2H), 7.13 (d, $J=8.8 \mathrm{~Hz}, 2 \mathrm{H}), 6.69$ (d, $J=3.2 \mathrm{~Hz}, 1 \mathrm{H}), 5.16(\mathrm{~s}, 2 \mathrm{H}) ;{ }^{13} \mathrm{C}$ NMR (100 $\left.\mathrm{MHz}, \mathrm{CDCl}_{3}\right): \delta 157.7,137.04,136.59,133.38,129.28,128.99,128.56,128.44,127.81,126.24$, 122.5, 121.3, 120.4, 116.0, 110.7, 103.2, 70.7. IR $v\left(\mathrm{~cm}^{-1}\right) 3480(\mathrm{w}), 2900(\mathrm{~m}), 1550(\mathrm{~s})$. HRMS $\left[\mathrm{C}_{21} \mathrm{H}_{17} \mathrm{NO}+\mathrm{H}^{+}\right]$calcd $=300.1383$, found $\mathrm{m} / \mathrm{z}=300.1384$

\section{6-Methoxy- $N$-(p-tolyl)pyridin-2-amine}




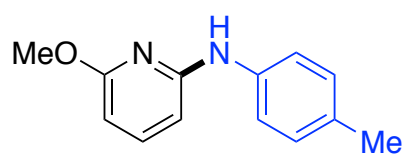

Colorless liquid, yield $67 \mathrm{mg}$ (89\%), $\mathrm{R}_{f} 0.2$ (9:1, hexanes/ethyl acetate). ${ }^{1} \mathrm{H}$ NMR (400 MHz, $\left.\mathrm{CDCl}_{3}\right): \delta 7.28(\mathrm{t}, J=4 \mathrm{~Hz}, 1 \mathrm{H}), 7.15(\mathrm{~d}, J=8.4 \mathrm{~Hz}, 2 \mathrm{H}), 7.29(\mathrm{~d}, J=8 \mathrm{~Hz}, 2 \mathrm{H}), 6.24(\mathrm{~d}, J=8$ $\mathrm{Hz}, 2 \mathrm{H}), 6.07$ (d, $J=8 \mathrm{~Hz}, 1 \mathrm{H}), 3.80$ (s, 3H), 2.23 (s, 3H); ${ }^{13} \mathrm{C}$ NMR (100 MHz, $\left.\mathrm{CDCl}_{3}\right): \delta 163.4$, 155.1, 140.4, 138.2, 132.5, 130, 120.9, 100.0, 99.5, 53.6, 21.1. IR $v\left(\mathrm{~cm}^{-1}\right) 3490$ (b), 2942(m), $1580(\mathrm{w})$. HRMS $\left[\mathrm{C}_{13} \mathrm{H}_{15} \mathrm{~N}_{2} \mathrm{O}+\mathrm{H}^{+}\right]$calcd $=215.1179$, found $\mathrm{m} / \mathrm{z}=215.1180$.

\section{4-(6-Methoxypyridin-2-yl)morpholine}

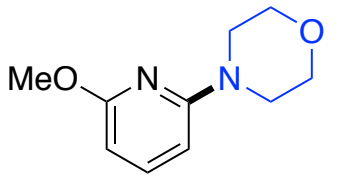

Colorless liquid, yield $61 \mathrm{mg}(87 \%), \mathrm{R}_{f} 0.3$ (9:1, hexanes/ethyl acetate). ${ }^{1} \mathrm{H}$ NMR (400 MHz, $\left.\mathrm{CDCl}_{3}\right): \delta 7.41(\mathrm{t}, J=8 \mathrm{~Hz}, 1 \mathrm{H}), 6.14(\mathrm{~d}, J=8.4 \mathrm{~Hz}, 1 \mathrm{H}), 6.12(\mathrm{~d}, J=8.8 \mathrm{~Hz}, 1 \mathrm{H}), 3.87(\mathrm{~s}, 3 \mathrm{H})$, $3.82(\mathrm{t}, J=5.2 \mathrm{~Hz}, 4 \mathrm{H}), 3.48(\mathrm{t}, J=4.4 \mathrm{~Hz}, 4 \mathrm{H})$.

\section{4-Methoxy- $N$-phenylaniline ${ }^{14}$}

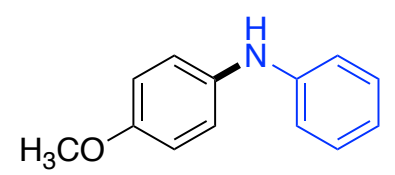

White Solid, yield $48 \mathrm{mg}$ (97\%), $\mathrm{R}_{f} 0.3$ (9:1, hexanes/ethyl acetate). ${ }^{1} \mathrm{H}$ NMR (400 $\left.\mathrm{MHz}, \mathrm{CDCl}_{3}\right)$ :

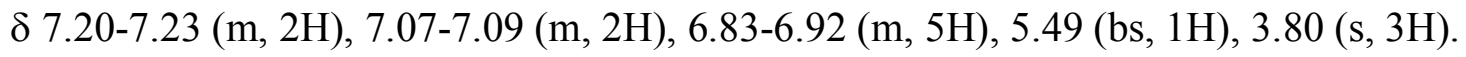

\section{1-Benzyl- $N$-(3,5-bis(trifluoromethyl)phenyl)-1 $H$-indol-5-amine}

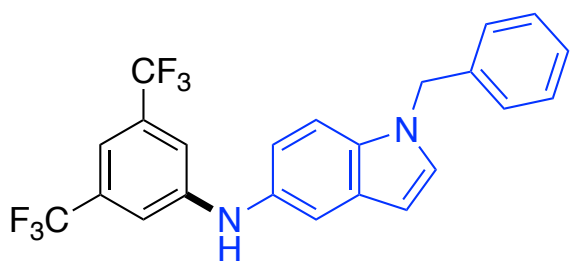

Waxy solid, yield $93 \mathrm{mg}$ (71\%), $\mathrm{R}_{f} 0.3$ (9:1, hexanes/ethyl acetate). ${ }^{1} \mathrm{H}$ NMR $\left(500 \mathrm{MHz}, \mathrm{CDCl}_{3}\right)$ : $\delta 7.47(\mathrm{~s}, 1 \mathrm{H}), 7.37-7.3(\mathrm{~m}, 4 \mathrm{H}), 7.23-7.17(\mathrm{~m}, 6 \mathrm{H}), 7.01(\mathrm{~d}, J=8 \mathrm{~Hz}, 1 \mathrm{H}), 6.55(\mathrm{~d}, J=8 \mathrm{~Hz}$, 1H), $5.92(\mathrm{~s}, 1 \mathrm{H}), 5.35$ (s, 2H); ${ }^{13} \mathrm{C} \mathrm{NMR}\left(125 \mathrm{MHz}, \mathrm{CDCl}_{3}\right): \delta$ 147.6, 136.9, 134.0, 132.24, 131.84 
$\left(\mathrm{q},{ }^{2} J=23.5 \mathrm{~Hz}\right) 129.2,128.5,127.7,126.5,123.2\left(\mathrm{q},{ }^{I} J=271.25 \mathrm{~Hz}\right) 118.55,115.58,113.00$, 110.89, 110.56, 101.34, 50.0; ${ }^{19} \mathrm{~F}$ NMR (376 MHz, $\left.\mathrm{CDCl}_{3}\right)$ : -63.32 ppm. IR $v\left(\mathrm{~cm}^{-1}\right) 31400(\mathrm{~s})$ 2900(m), 1550(s), 1470(w). HRMS $\left[\mathrm{C}_{23} \mathrm{H}_{17} \mathrm{~N}_{2} \mathrm{~F}_{6}+\mathrm{H}^{+}\right]$calcd $=435.1290$, found $\mathrm{m} / \mathrm{z}=435.1293$.

\section{$N$-(p-Tolyl)-3,5-bis(trifluoromethyl)aniline}<smiles>Cc1ccc(Nc2cc(C(F)(F)F)cc(C(F)(F)F)c2)cc1</smiles>

Yellow liquid, yield $77.6 \mathrm{mg}(81 \%), \mathrm{R}_{f} 0.3$ (9:1, hexanes/ethyl acetate). ${ }^{1} \mathrm{H}$ NMR (400 MHz, $\mathrm{CDCl}_{3}$ ): $\delta 7.35-7.32(\mathrm{~m}, 3 \mathrm{H}), 7.25(\mathrm{~d}, J=8 \mathrm{~Hz}, 2 \mathrm{H}), 7.12$ (d, $\left.J=8 \mathrm{~Hz}, 2 \mathrm{H}\right), 5.92(\mathrm{bs}, 1 \mathrm{H}), 2.42$ (s,

$3 \mathrm{H}) ;{ }^{13} \mathrm{C}$ NMR (100 MHz, $\left.\mathrm{CDCl}_{3}\right): \delta 146.1,137.5,134.0,132.6$ (q, $\left.{ }^{2} J=33.5 \mathrm{~Hz}\right), 130.4,123.4$ (q, $\left.{ }^{2} J=271.1 \mathrm{~Hz}\right), 121.5,114.4,112.3,20.9 ;{ }^{19} \mathrm{~F} \mathrm{NMR}\left(376 \mathrm{MHz}, \mathrm{CDCl}_{3}\right):-63.32 \mathrm{ppm} . \mathrm{HRMS}$ $\left[\mathrm{C}_{15} \mathrm{H} 11 \mathrm{NF}_{6}+\mathrm{H}\right]$ calcd $=320.0823$, found $\mathrm{m} / \mathrm{z}=320.0816$.

\section{2-((4-Methoxyphenyl)ethynyl)pyrimidine ${ }^{15}$}

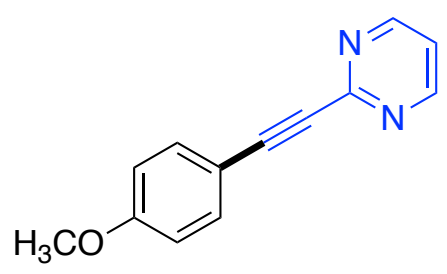

Off-white solid, yield $56 \mathrm{mg}$ (89\%), $\mathrm{R}_{f} 0.34$ (4:1, hexanes/ethyl acetate). ${ }^{1} \mathrm{H}$ NMR (400 MHz, $\left.\mathrm{CDCl}_{3}\right): \delta 8.74(\mathrm{~d}, J=5.2 \mathrm{~Hz}, 2 \mathrm{H}), 7.62(\mathrm{~d}, J=8 \mathrm{~Hz}, 2 \mathrm{H}), 7.21(\mathrm{t}, J=4.8 \mathrm{~Hz}, 1 \mathrm{H}), 6.9(\mathrm{~d}, J=8$ $\mathrm{Hz}, 2 \mathrm{H}), 3.84$ (s, 3H).

\section{1,2-Bis(4-methoxyphenyl)ethyne ${ }^{16}$}

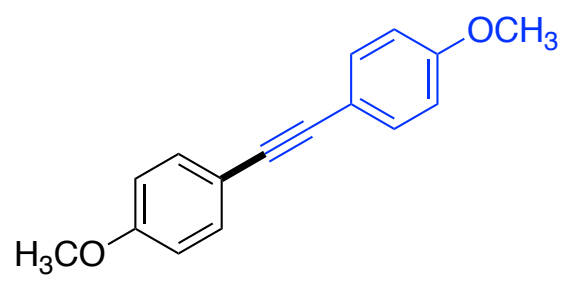

Off-white solid, yield $61 \mathrm{mg}(86 \%), \mathrm{R}_{f} 0.3$ (Hexanes). ${ }^{1} \mathrm{H}$ NMR $\left(400 \mathrm{MHz}, \mathrm{CDCl}_{3}\right): \delta 7.46(\mathrm{~d}, J$ $=8 \mathrm{~Hz}, 4 \mathrm{H}), 6.8(\mathrm{~d}, J=8 \mathrm{~Hz}, 4 \mathrm{H}), 3.82(\mathrm{~s}, 6 \mathrm{H})$. 


\section{1-((4-Methoxyphenyl)ethynyl)-3,5-bis(trifluoromethyl)benzene ${ }^{17}$}

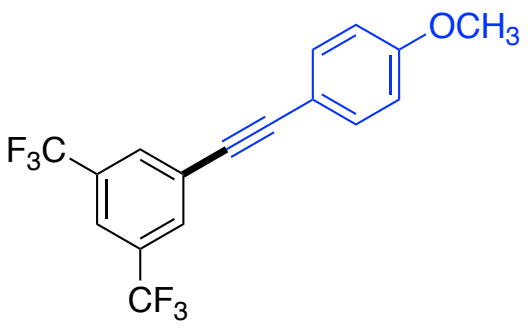

Off-white solid, yield $61 \mathrm{mg}(87 \%), \mathrm{R}_{f} 0.4$ (Hexanes). ${ }^{1} \mathrm{H}$ NMR (400 MHz, $\left.\mathrm{CDCl}_{3}\right): \delta 7.93$ (s, 2H), $7.78(\mathrm{~s}, 1 \mathrm{H}), 7.5(\mathrm{~d}, J=8 \mathrm{~Hz}, 2 \mathrm{H}), 6.91(\mathrm{~d}, J=8 \mathrm{~Hz}, 2 \mathrm{H}), 3.84(\mathrm{~s}, 3 \mathrm{H}) ;{ }^{19} \mathrm{~F} \mathrm{NMR}(376 \mathrm{MHz}$, $\left.\mathrm{CDCl}_{3}\right):-63.32$.

\section{4-(2-Nitrophenyl)dibenzo $[\boldsymbol{b}, \boldsymbol{d}]$ furan ${ }^{18}$}

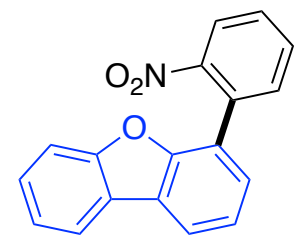

Waxy liquid, yield $63.3 \mathrm{mg}(73 \%), \mathrm{R}_{f} 0.3$ (4:1 hexanes:ethylacetate). ${ }^{1} \mathrm{H} \mathrm{NMR}\left(400 \mathrm{MHz}, \mathrm{CDCl}_{3}\right)$ : $\delta 7.9(\mathrm{dd}, J=7.2 \mathrm{~Hz}, 1.2 \mathrm{~Hz}, 1 \mathrm{H}), 7.82-7.76(\mathrm{~m}, 2 \mathrm{H}), 7.53$ (td, $J=6.4,1.2 \mathrm{~Hz}, 1 \mathrm{H}), 7.44-7.37$ (m, 2H), 7.31-7.22 (m, 4H), 7.17-7.13 (m, 1H).

\section{2-(4-Chlorophenyl)benzofuran ${ }^{19}$}

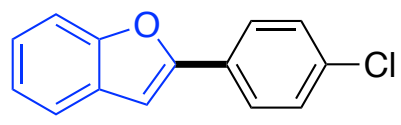

Waxy liquid, yield $60.8 \mathrm{mg}(89 \%), \mathrm{R}_{f} 0.3$ (9:1 hexanes:ethylacetate). ${ }^{1} \mathrm{H} \mathrm{NMR}\left(400 \mathrm{MHz}, \mathrm{CDCl}_{3}\right)$ : $\delta 8.04(\mathrm{~d}, J=8 \mathrm{~Hz}, 2 \mathrm{H}), 7.83(\mathrm{~d}, J=8 \mathrm{~Hz}, 1 \mathrm{H}), 7.77$ (d, $J=8 \mathrm{~Hz}, 1 \mathrm{H}), 7.67$ (d, $J=8 \mathrm{~Hz}, 2 \mathrm{H})$, $7.56-7.47(\mathrm{~m}, 3 \mathrm{H})$. 


\section{REFERENCES}

1) Jovanovic, M. V.; Biehl, E. R. 13C Nuclear Magnetic Resonance of Some Derivatives of Phenothiazines, Pyridobenzothiazines and Phenoxazines. Org. Magn. Reson. 1984, 22, 491-504.

2) Rull, S. G.; Funes-Ardoiz, I.; Maya, C.; Maseras, F.; Fructos, M. R.; Belderrain, T. R.; Nicasio, M. C. Elucidating the Mechanism of Aryl Aminations Mediated by NHCSupported Nickel Complexes: Evidence for a Nonradical Ni(0)/Ni(II) Pathway. ACS Catal. 2018, 8, 3733-3742.

3) Lee, H. G.; Won, J. E.; Kim, M. J.; Park, S. E.; Jung, K. J.; Bo, R. K.; Lee, S. G.; Yoon, Y. J. TBAF-Assisted Copper-Catalyzed N-Arylation and Benzylation of Benzazoles with Aryl and Benzyl Halides under the Ligand/Base/ Solvent-Free Conditions. J. Org. Chem. 2009, 74, 5675-5678.

4) Desmarets, C.; Champagne, B.; Walcarius, A.; Bellouard, C.; Omar-Amrani, R.; Ahajji, A.; Fort, Y.; Schneider, R. Facile Synthesis and Characterization of Naphthidines as a New Class of Highly Nonplanar Electron Donors Giving Robust Radical Cations. J. Org. Chem. 2006, 71, 1351-1361.

5) Chen, H.; Lei, M.; Hu, L. Synthesis of 1-Aryl Indoles via Coupling Reaction of Indoles and Aryl Halides Catalyzed by CuI/Metformin. Tetrahedron 2014, 70, 5626-5631.

6) Colacino, E.; Villebrun, L.; Martinez, J.; Lamaty, F. PEG3400-Cu2O-Cs2CO3: An Efficient and Recyclable Microwave-Enhanced Catalytic System for Ligand-Free Ullmann Arylation of Indole and Benzimidazole. Tetrahedron 2010, 66, 3730-3735.

7) Ogata, T.; Hartwig, J. F. ChemInform Abstract: Palladium-Catalyzed Amination of Aryl and Heteroaryl Tosylates at Room Temperature. J. Am. Chem. Soc. 2009, 40, 1384813849.

8) Deangelis, A. J.; Gildner, P. G.; Chow, R.; Colacot, T. J. Generating Active L-Pd(0) via Neutral or Cationic $\pi$-Allylpalladium Complexes Featuring Biaryl/Bipyrazolylphosphines: Synthetic, Mechanistic, and Structure-Activity Studies in Challenging Cross-Coupling Reactions. J. Org. Chem. 2015, 80, 6794-6813.

9) Matsumura, S.; Hlil, A. R.; Lepiller, C.; Gaudet, J.; Guay, D.; Shi, Z.; Holdcroft, S.; Hay, A. S. Ionomers for Proton Exchange Membrane Fuel Cells with Sulfonic Acid Groups on the End-Groups: Novel Branched Poly(Ether-Ketone)S. Am. Chem. Soc. Polym. Prepr. Div. Polym. Chem. 2008, 49, 511-512.

10) Park, S.-E.; Kang, S. B.; Jung, K.-J.; Won, J.-E.; Lee, S.-G.; Yoon, Y.-J. Efficient Palladium-Catalyzed Amination of Aryl Chlorides Using Dicyclo-hexylamino[(2,6Dimethyl)Morpholino]Phenylphosphine as a PN2 Ligand. Synthesis (Stuttg). 2009, 2009, 815-823.

11) Molina, P.; Alajarín, M.; Vidal, A.; Sánchez-Andrada, P. C=C-Conjugated Carbodiimides as 2-Azadienes in Intramolecular [4 2] Cycloadditions. One-Pot Preparation of Quinoline, $\alpha$-Carboline, and Quinindoline Derivatives. J. Org. Chem. 1992, 57, 929-939. 
12) Pawar, G. G.; Brahmanandan, A.; Kapur, M. Palladium(II)-Catalyzed, HeteroatomDirected, Regioselective C-H Nitration of Anilines Using Pyrimidine as a Removable Directing Group. Org. Lett. 2016, 18, 448-451.

13) Liu, X.; Zhang, S. Efficient Iron/Copper Cocatalyzed N-Arylation of Arylamines with Bromoarenes. Synlett 2011, 2, 1137-1142.

14) Carroll, M. A.; Wood, R. A. Arylation of Anilines: Formation of Diarylamines Using Diaryliodonium Salts. Tetrahedron 2007, 63, 11349-11354.

15) Peng, H.; Chen, Y. Q.; Mao, S. L.; Pi, Y. X.; Chen, Y.; Lian, Z. Y.; Meng, T.; Liu, S. H.; Yu, G. A. A General Catalyst for Suzuki-Miyaura and Sonogashira Reactions of Aryl and Heteroaryl Chlorides in Water. Org. Biomol. Chem. 2014, 12, 6944-6952.

16) Ghiringhelli, F.; Nattmann, L.; Bognar, S.; Van Gemmeren, M. The Direct Conversion of $\alpha$-Hydroxyketones to Alkynes. J. Org. Chem. 2019, 84, 983.

17) Liang, J. H.; Yang, L.; Wu, S.; Liu, S. S.; Cushman, M.; Tian, J.; Li, N. M.; Yang, Q. H.; Zhang, H. A.; Qiu, Y. J.; Xiang, L.; Ma, C.X.; Li, X.M.; Qing, H. Discovery of Efficient Stimulators for Adult Hippocampal Neurogenesis Based on Scaffolds in Dragon's Blood. Eur. J. Med. Chem. 2017, 136, 382-392.

18) Kato, T.; Yabunouchi, N.; Sado, T. US Patent-2014/0217393 A1.

19) Bering, L.; Paulussen, F. M.; Antonchick, A. P. Aerobic, Metal-Free, and Catalytic Dehydrogenative Coupling of Heterocycles: En Route to Hedgehog Signaling Pathway Inhibitors. Org. Lett. 2018, 20, 1978-1981. 
20. NMR SPECTRA

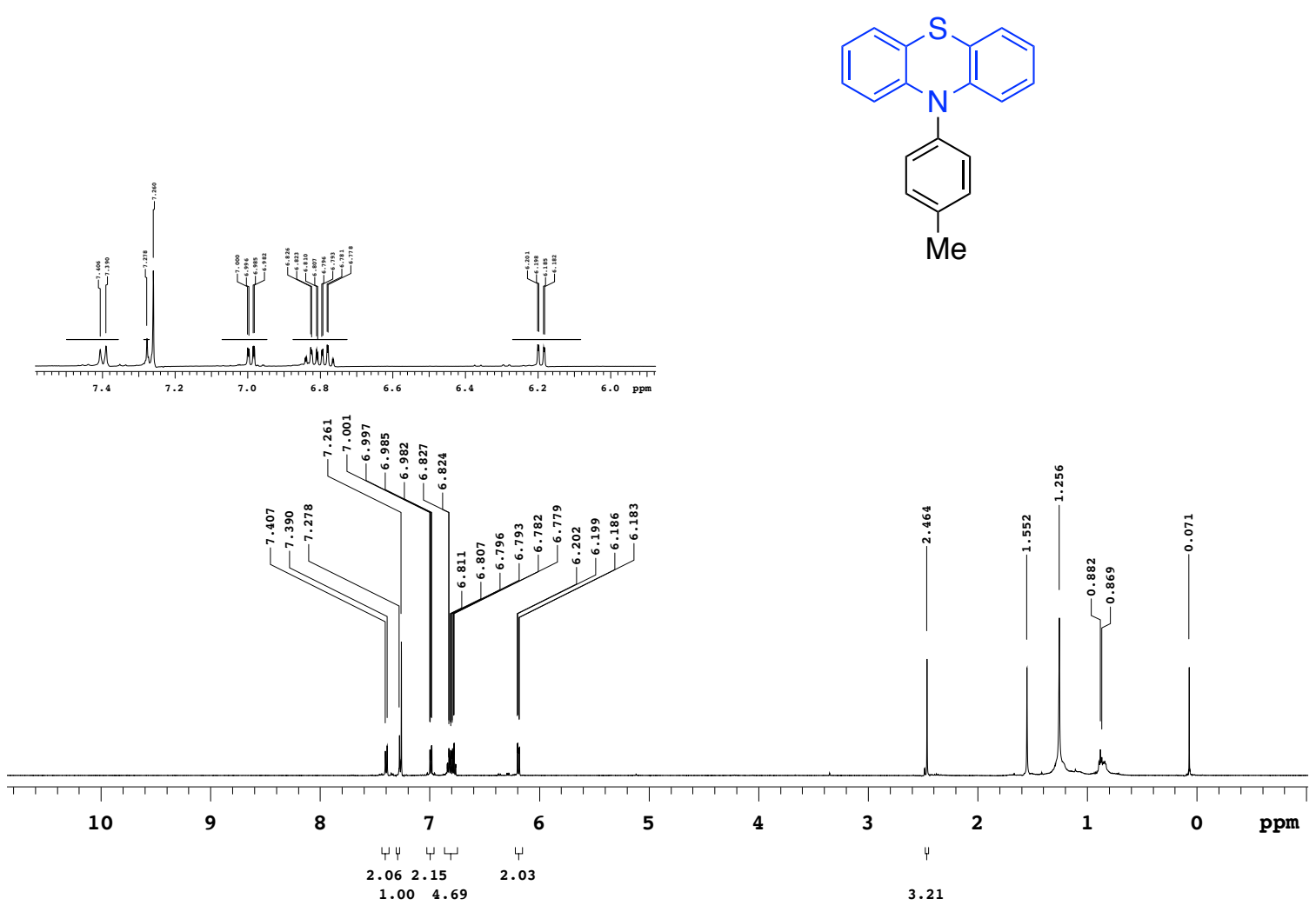



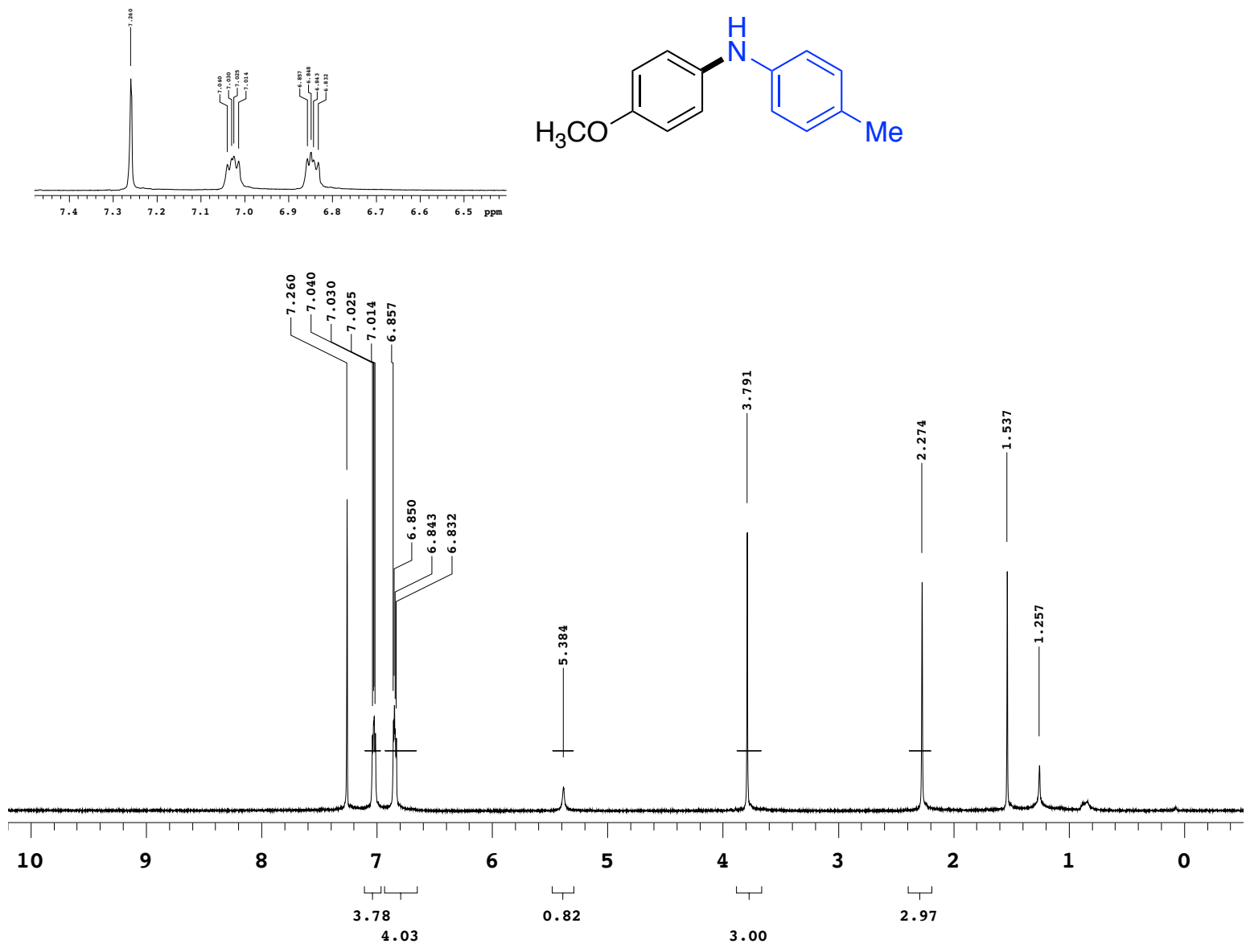

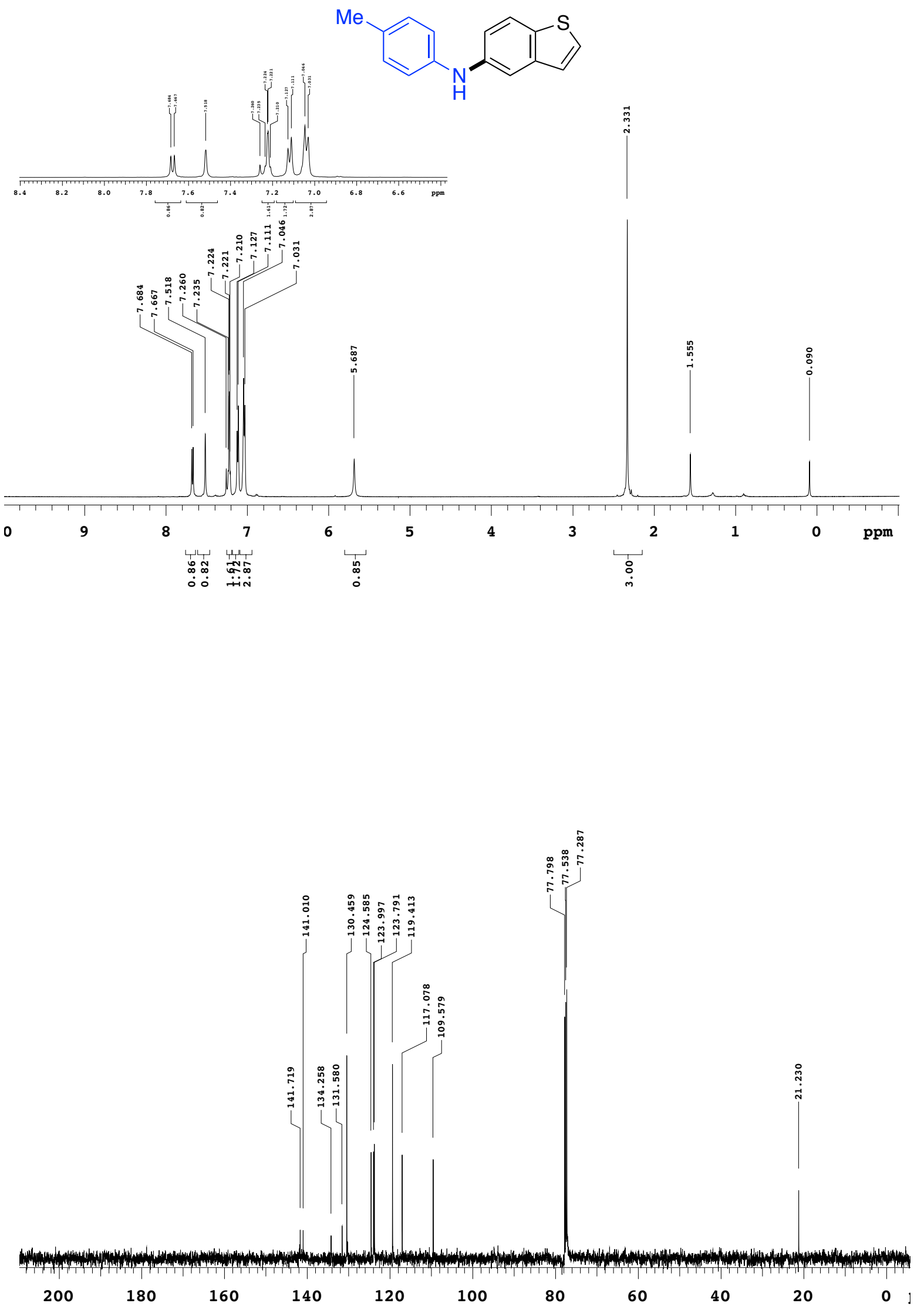


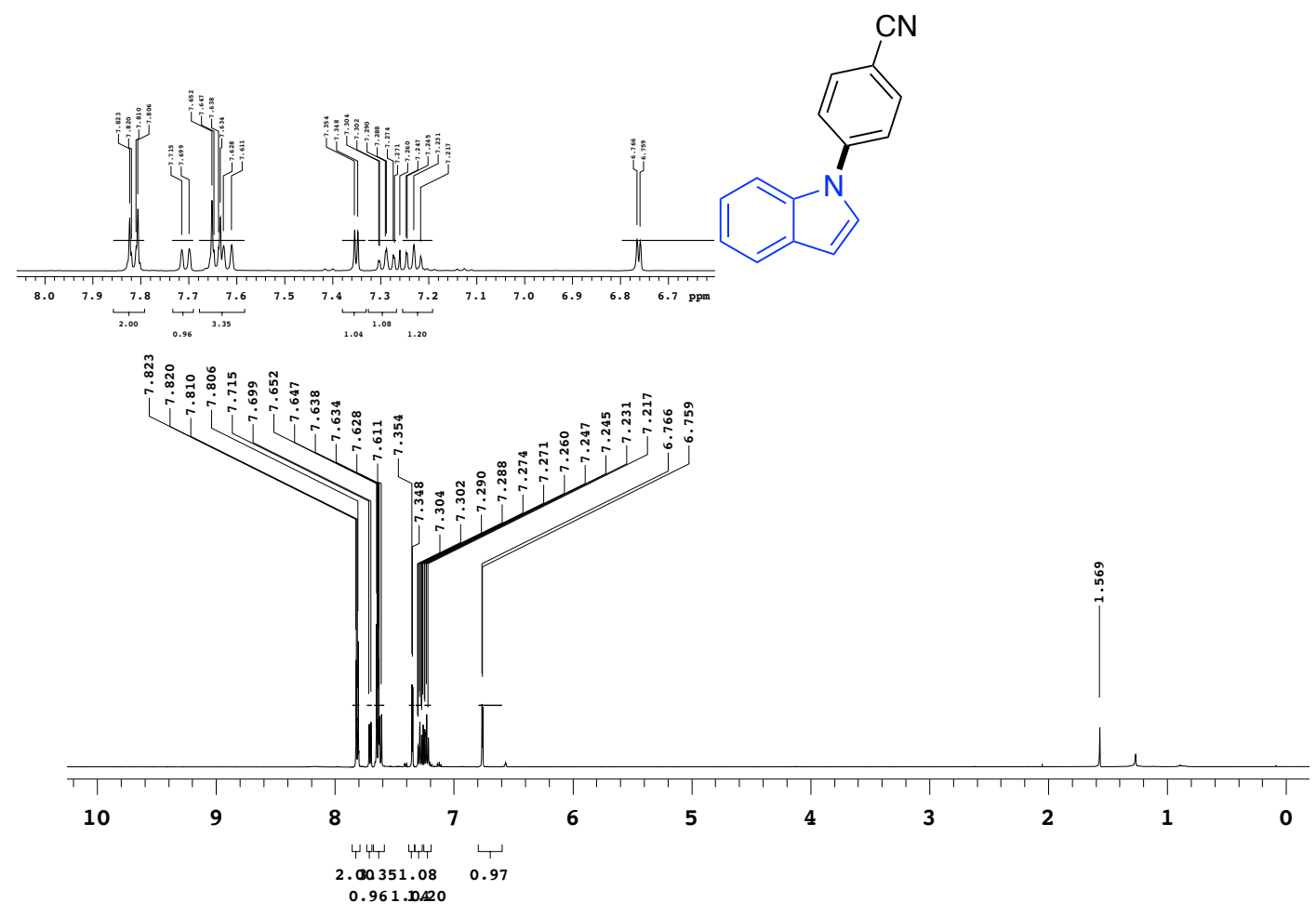



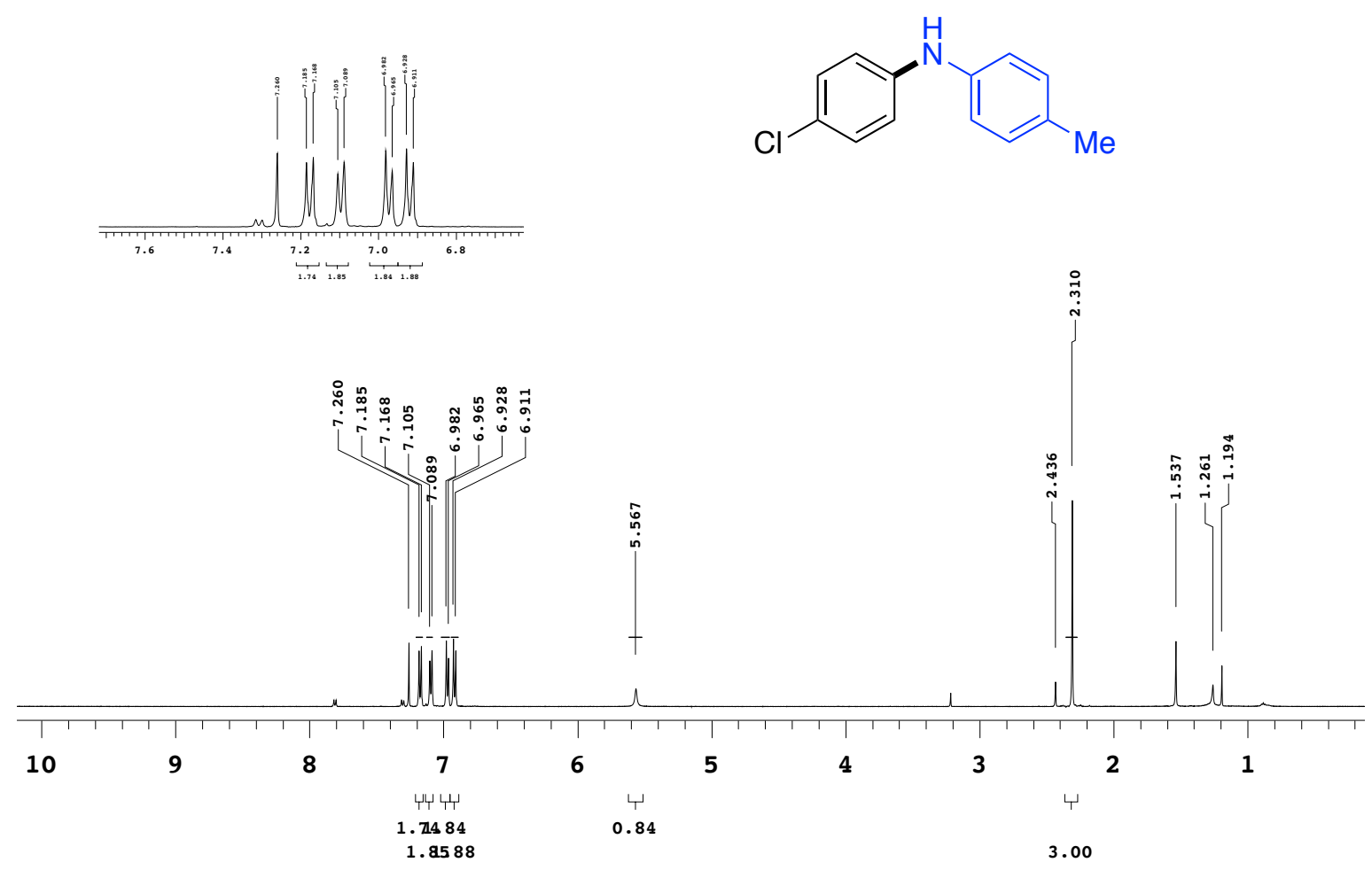

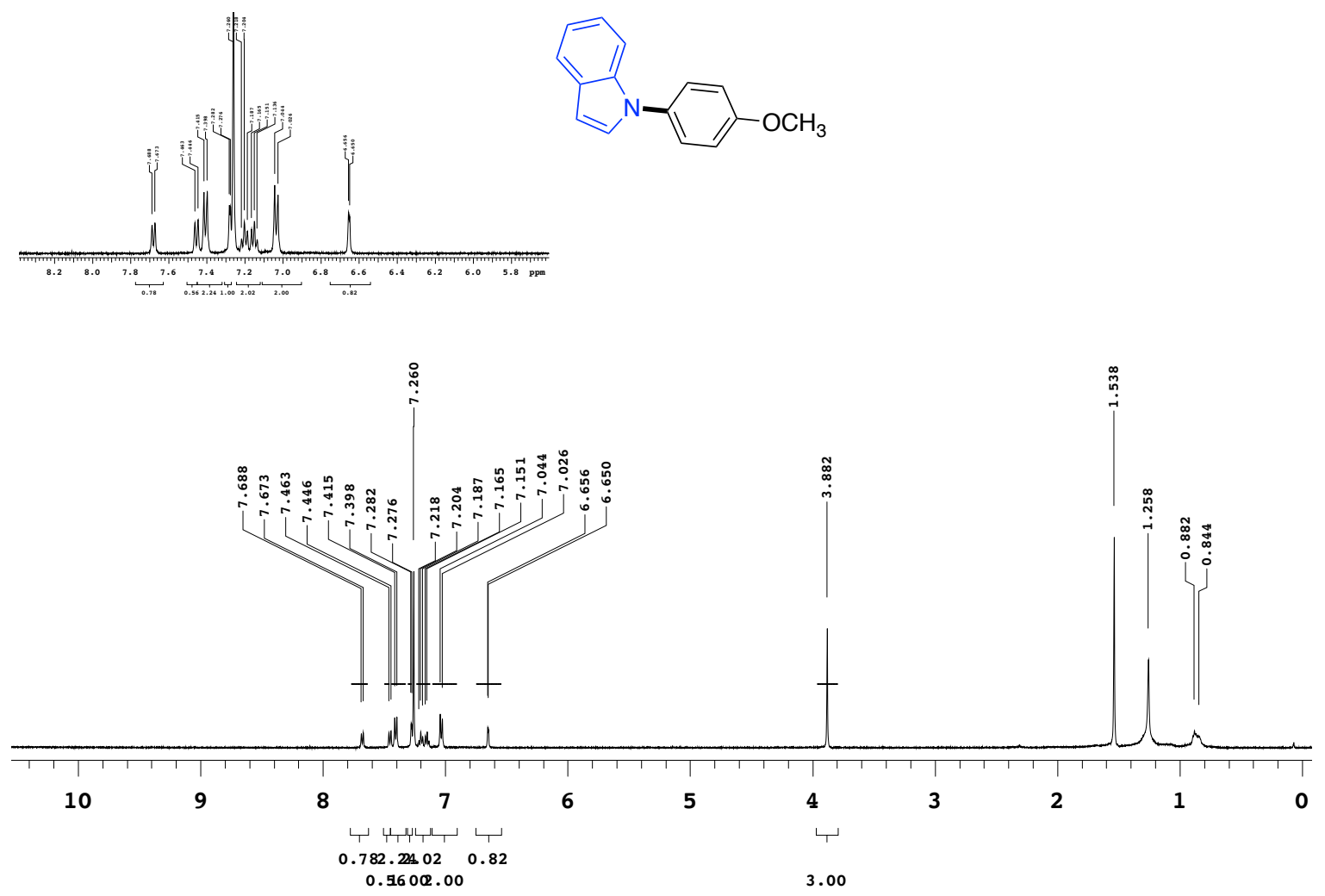

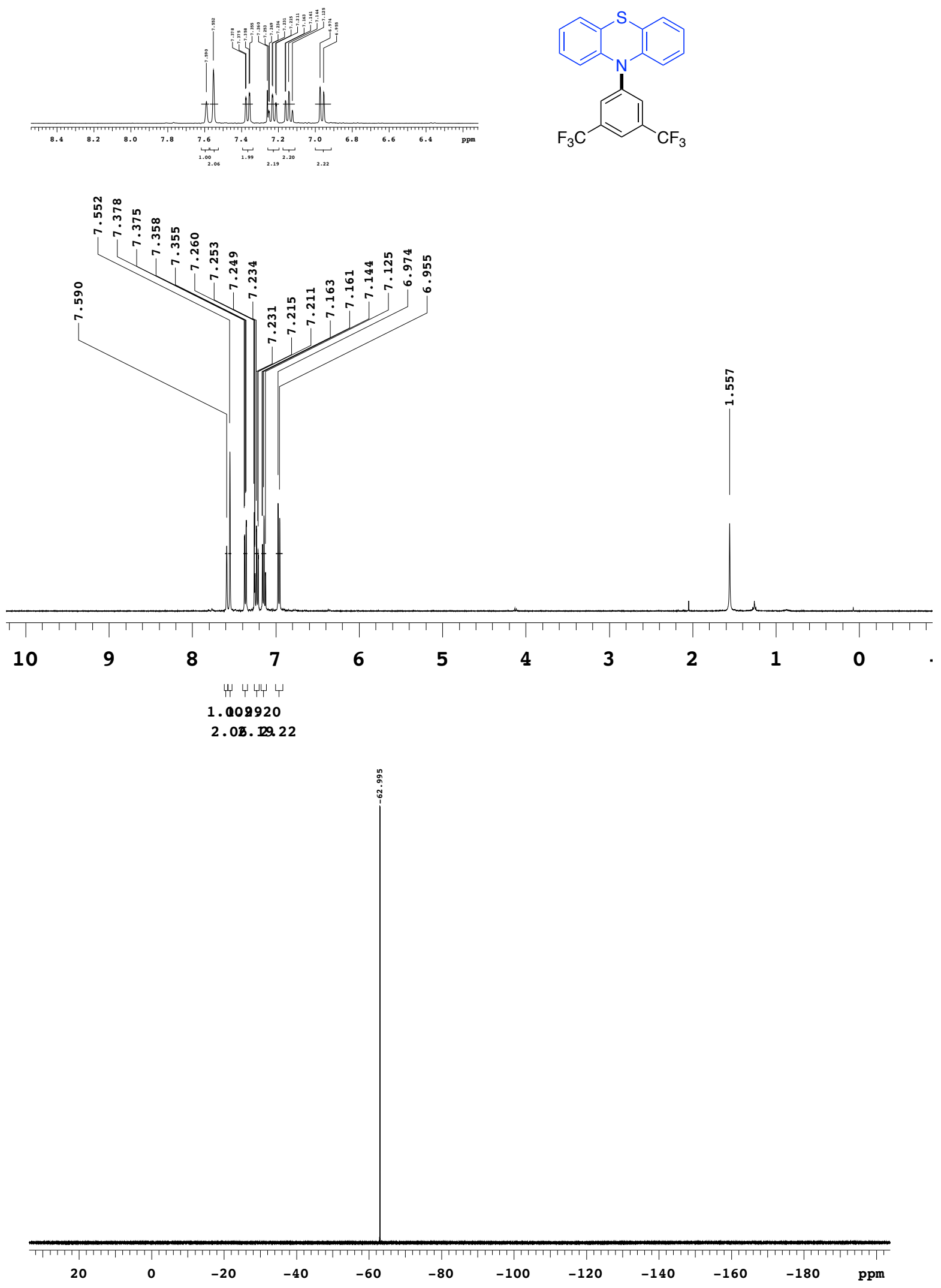


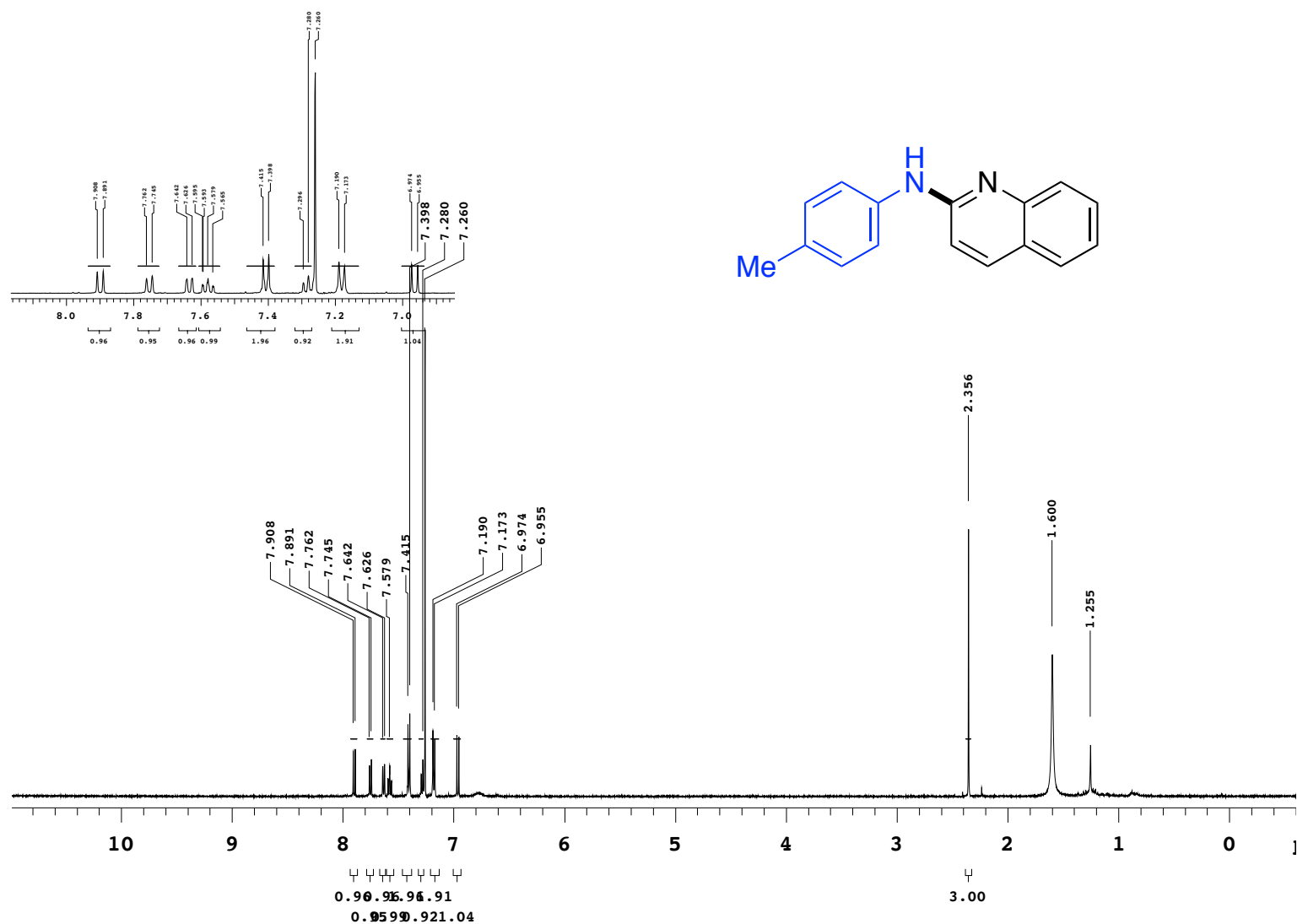




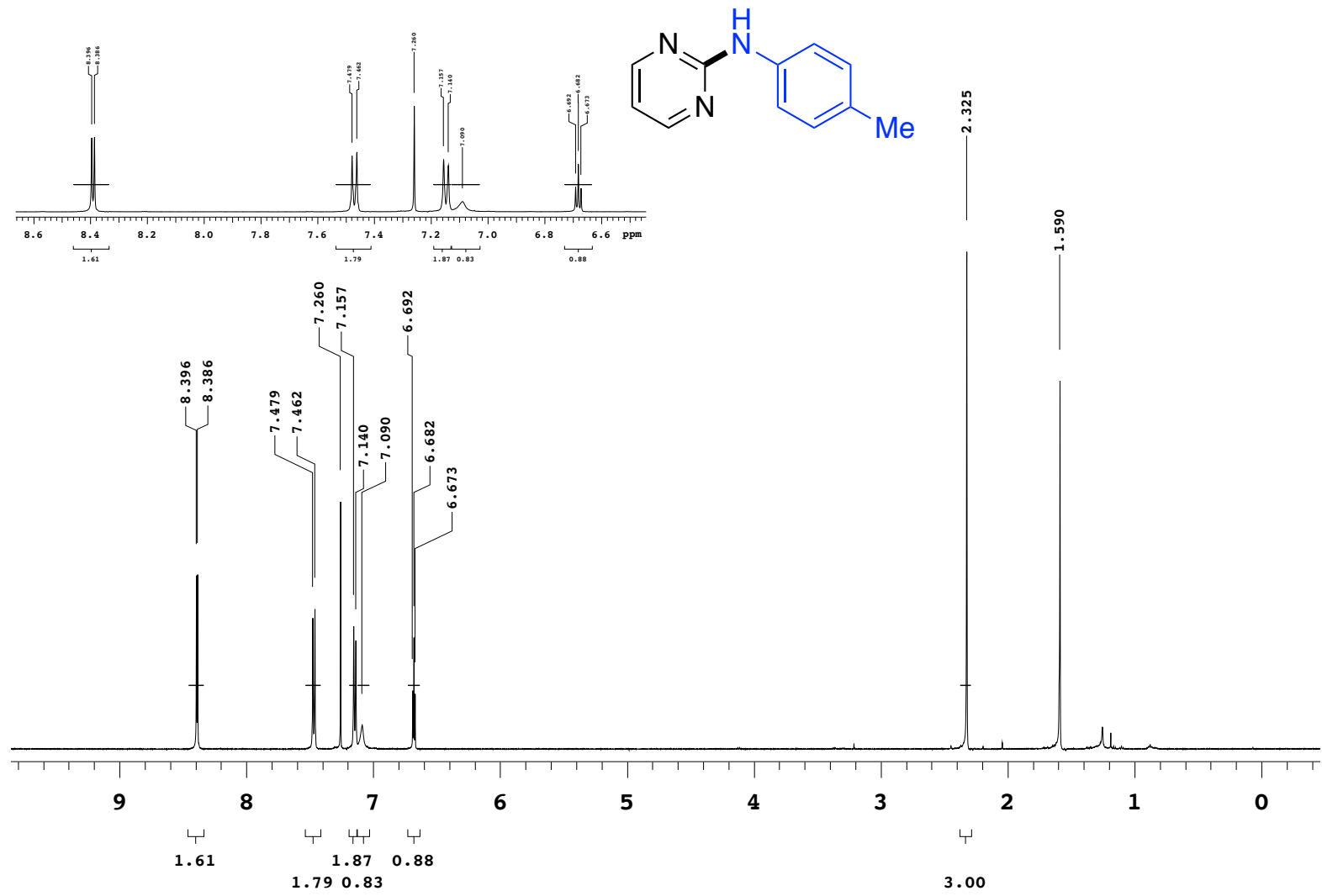



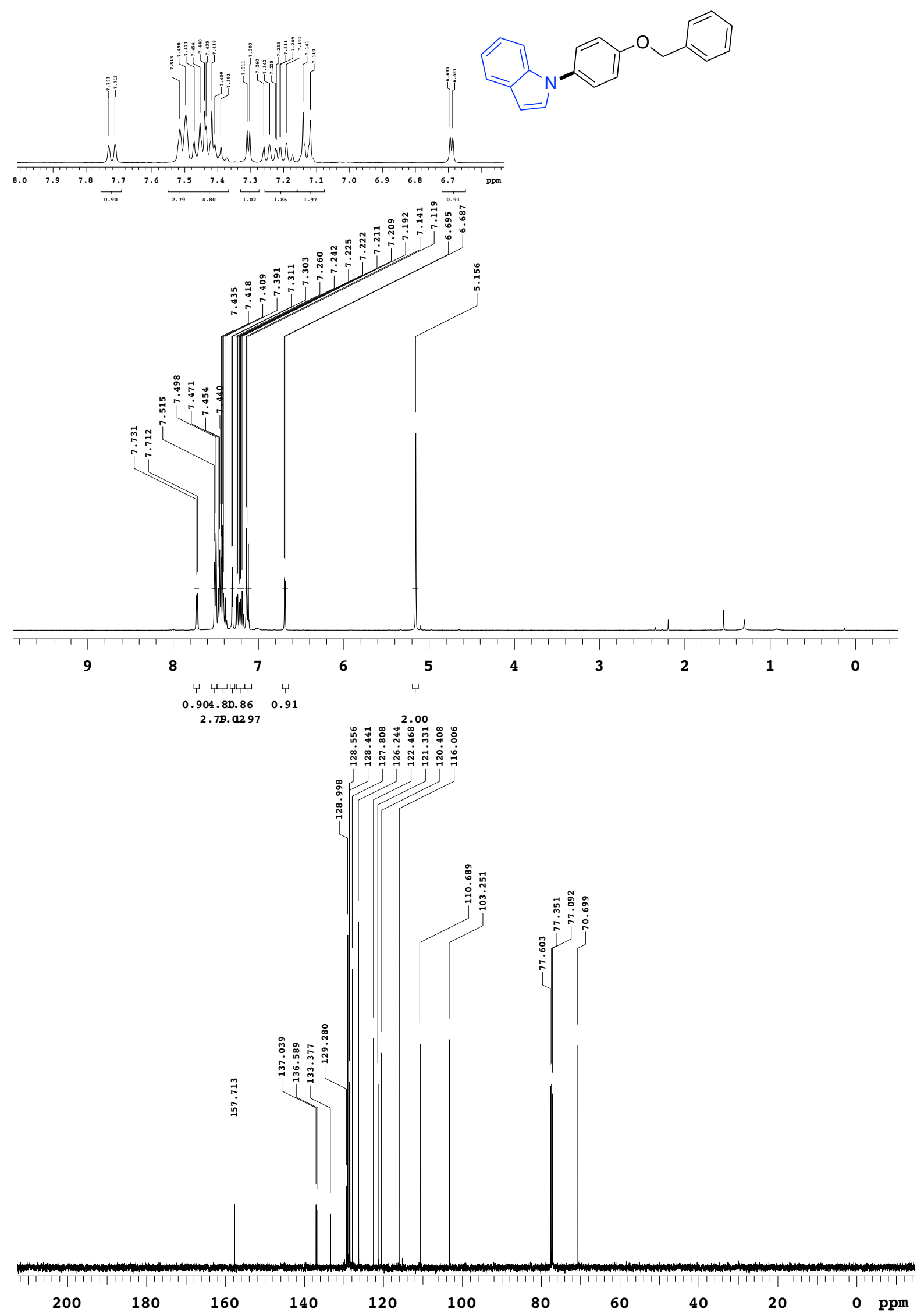

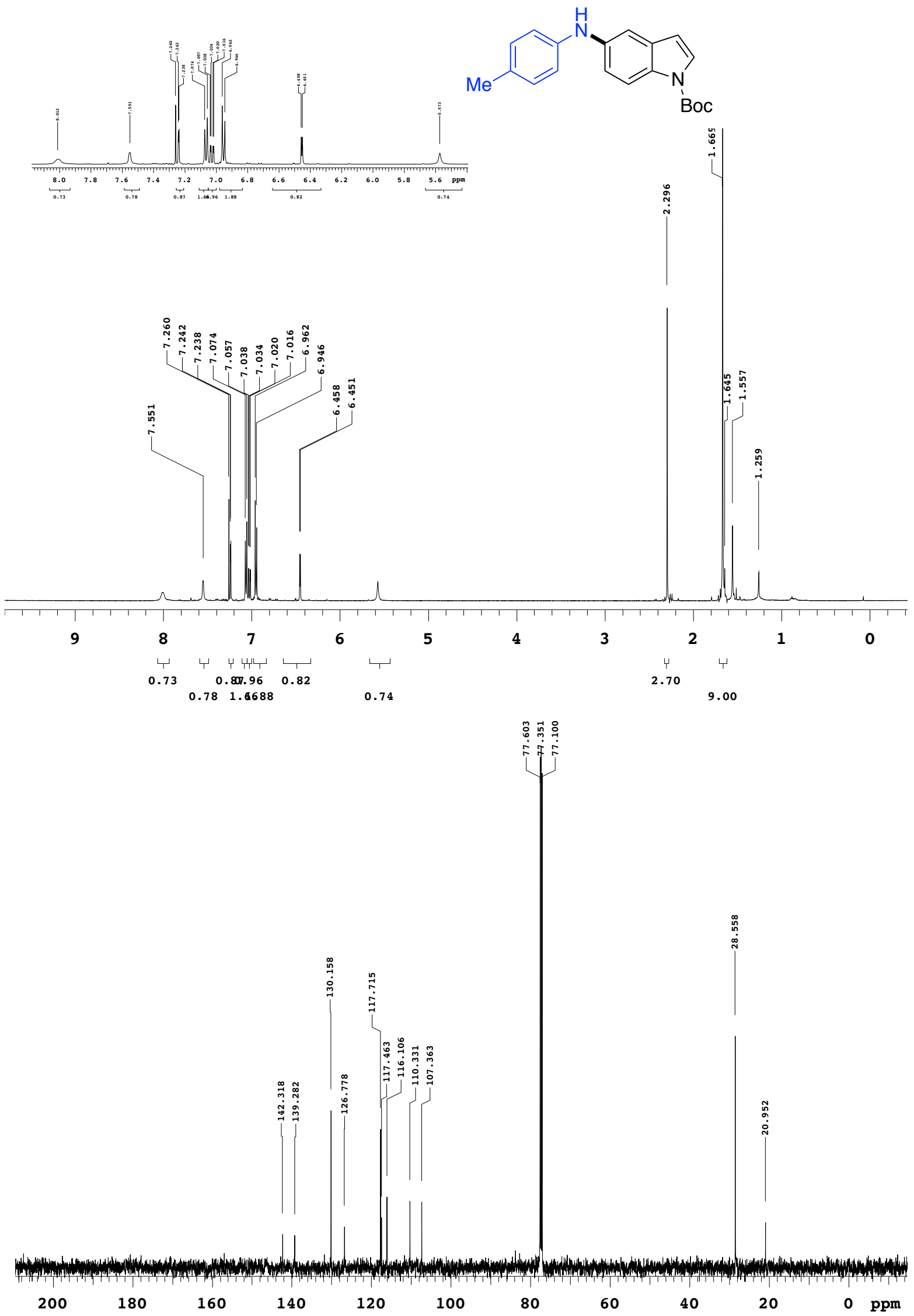

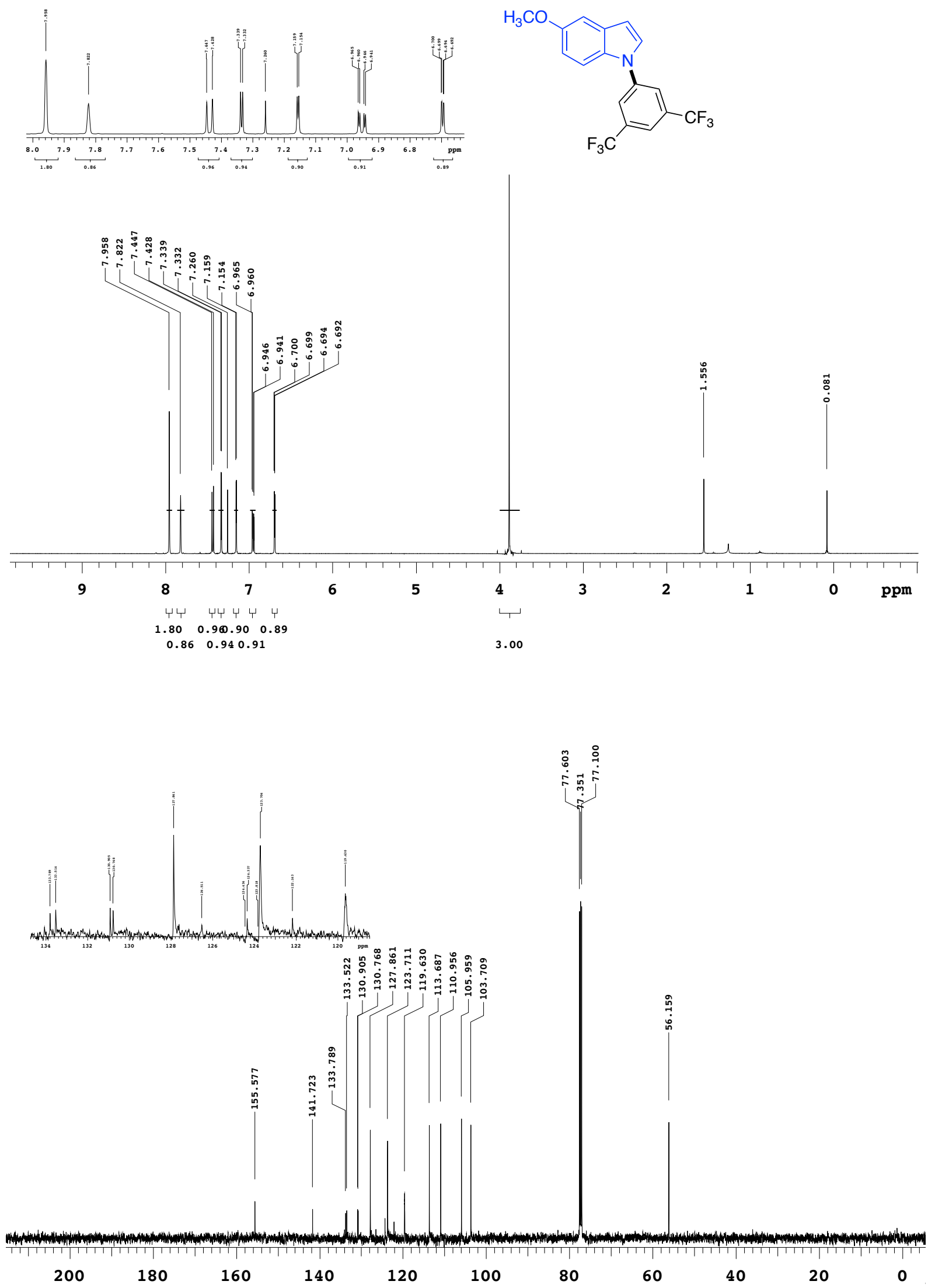


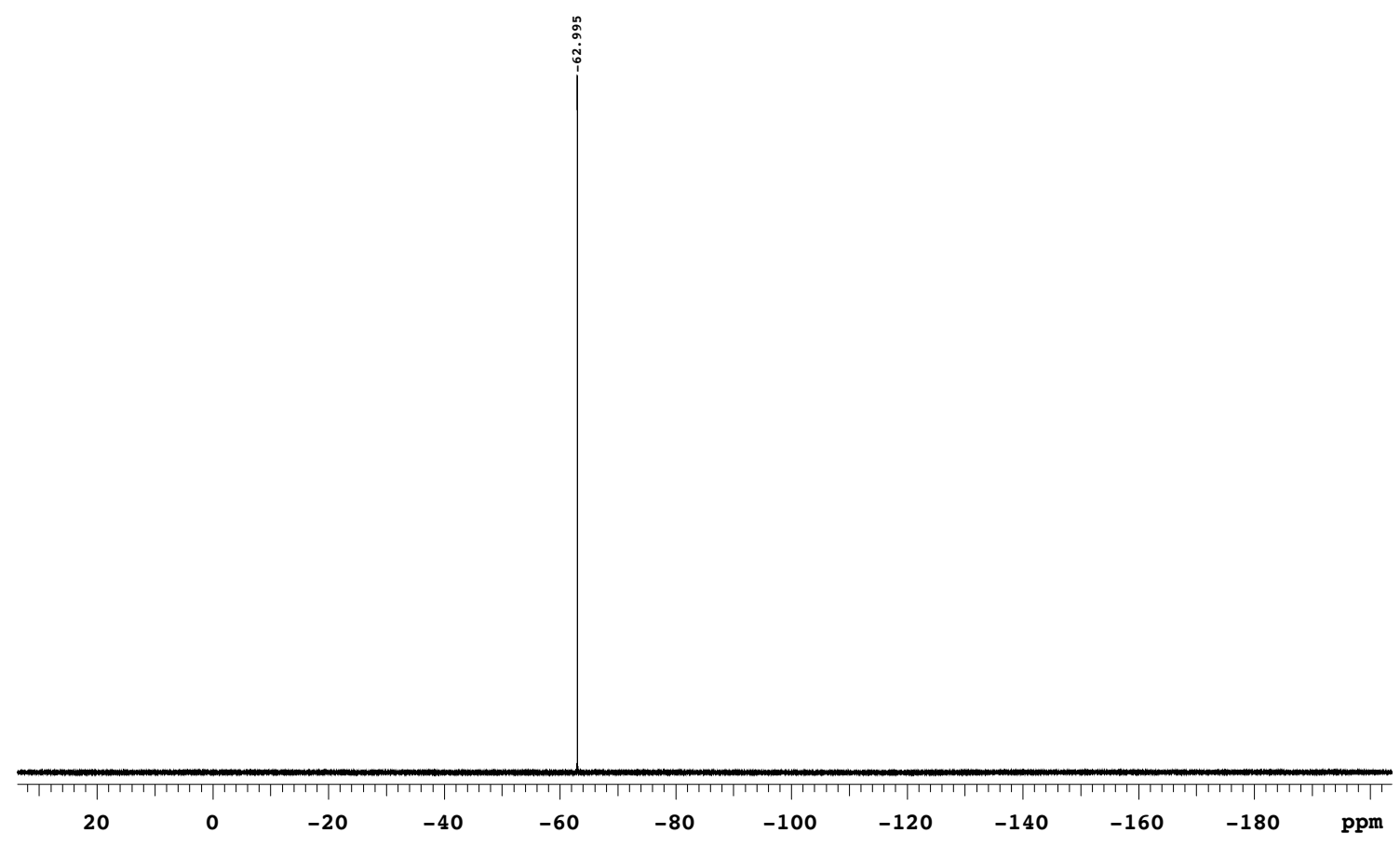




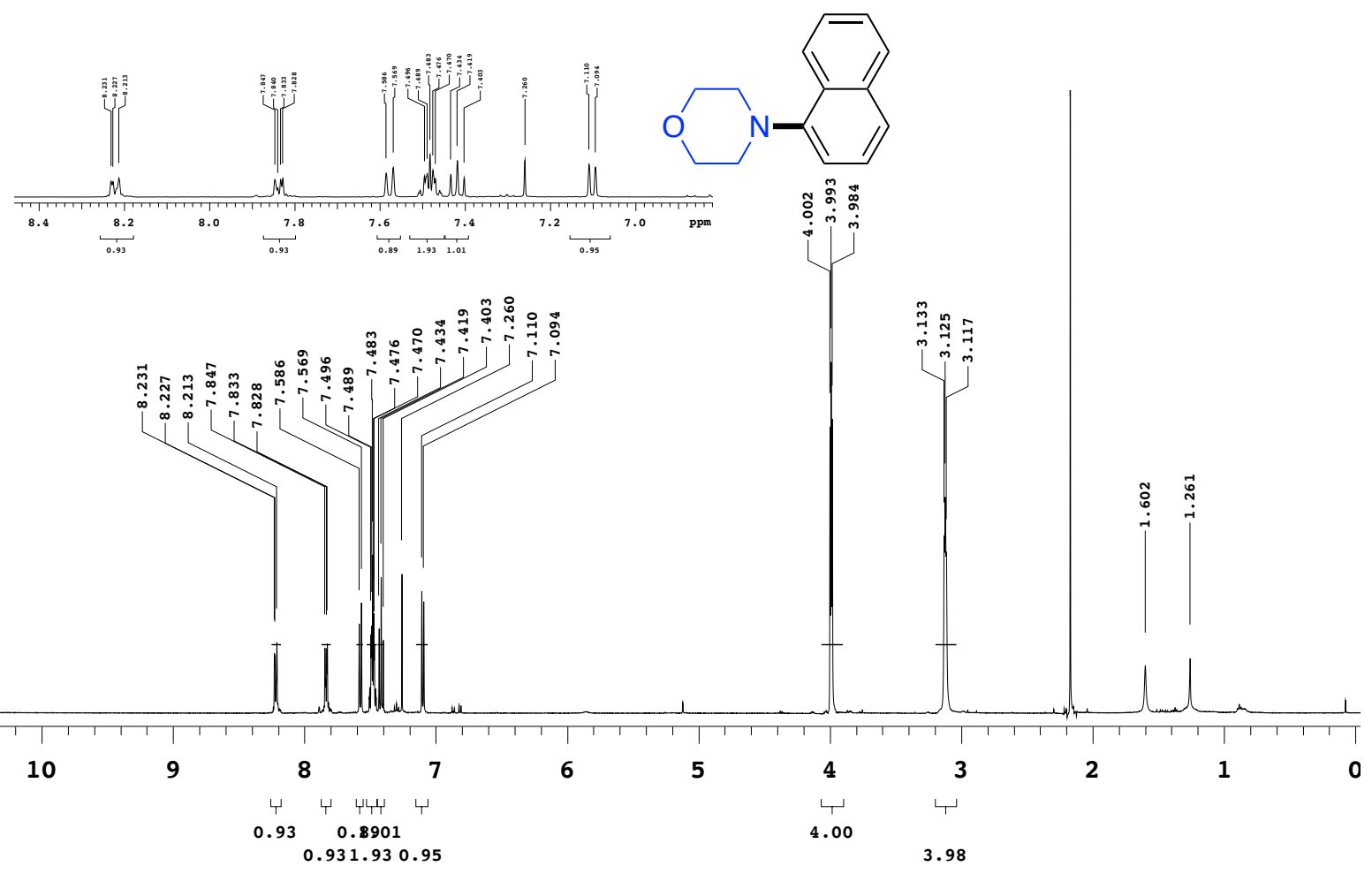



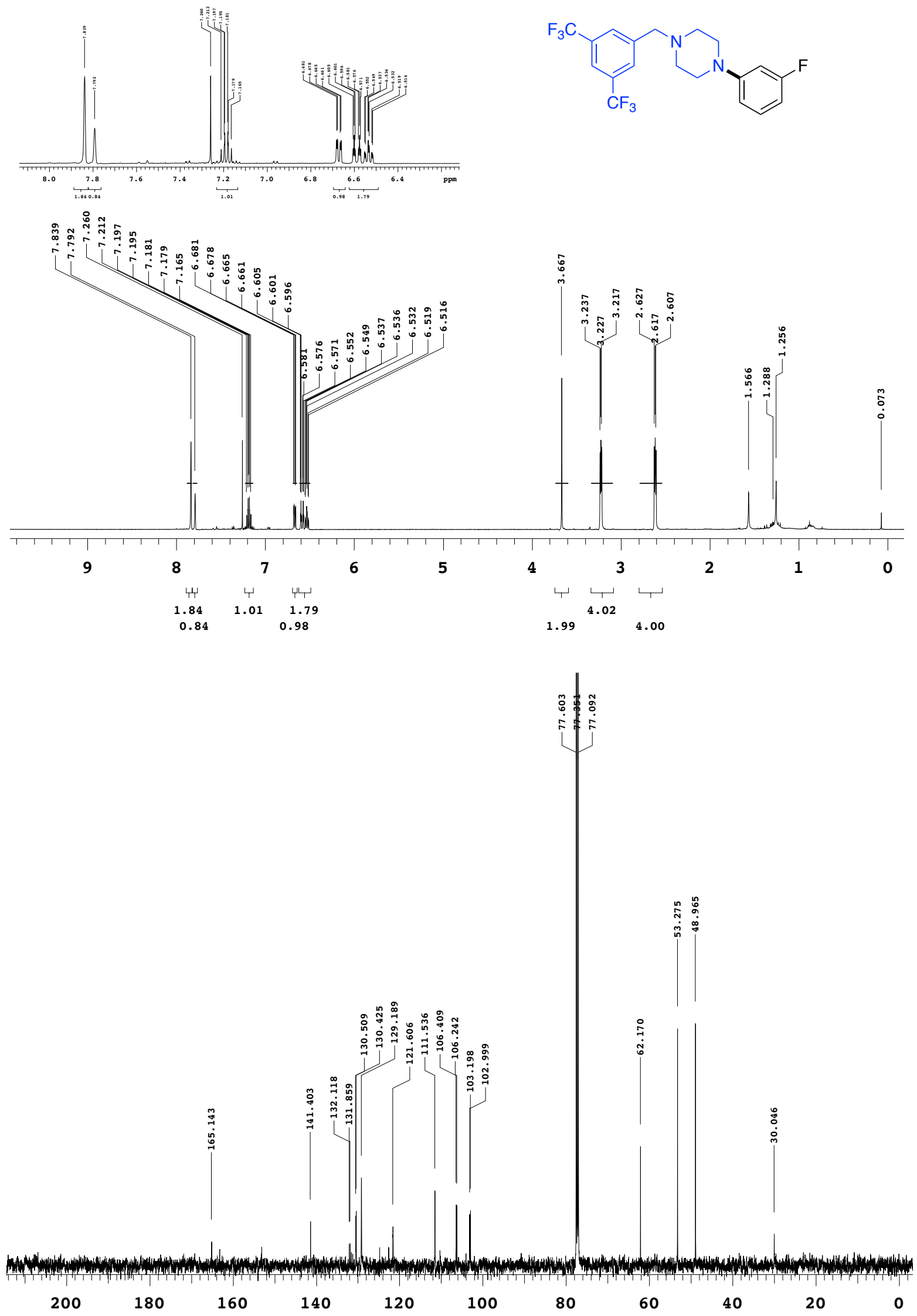

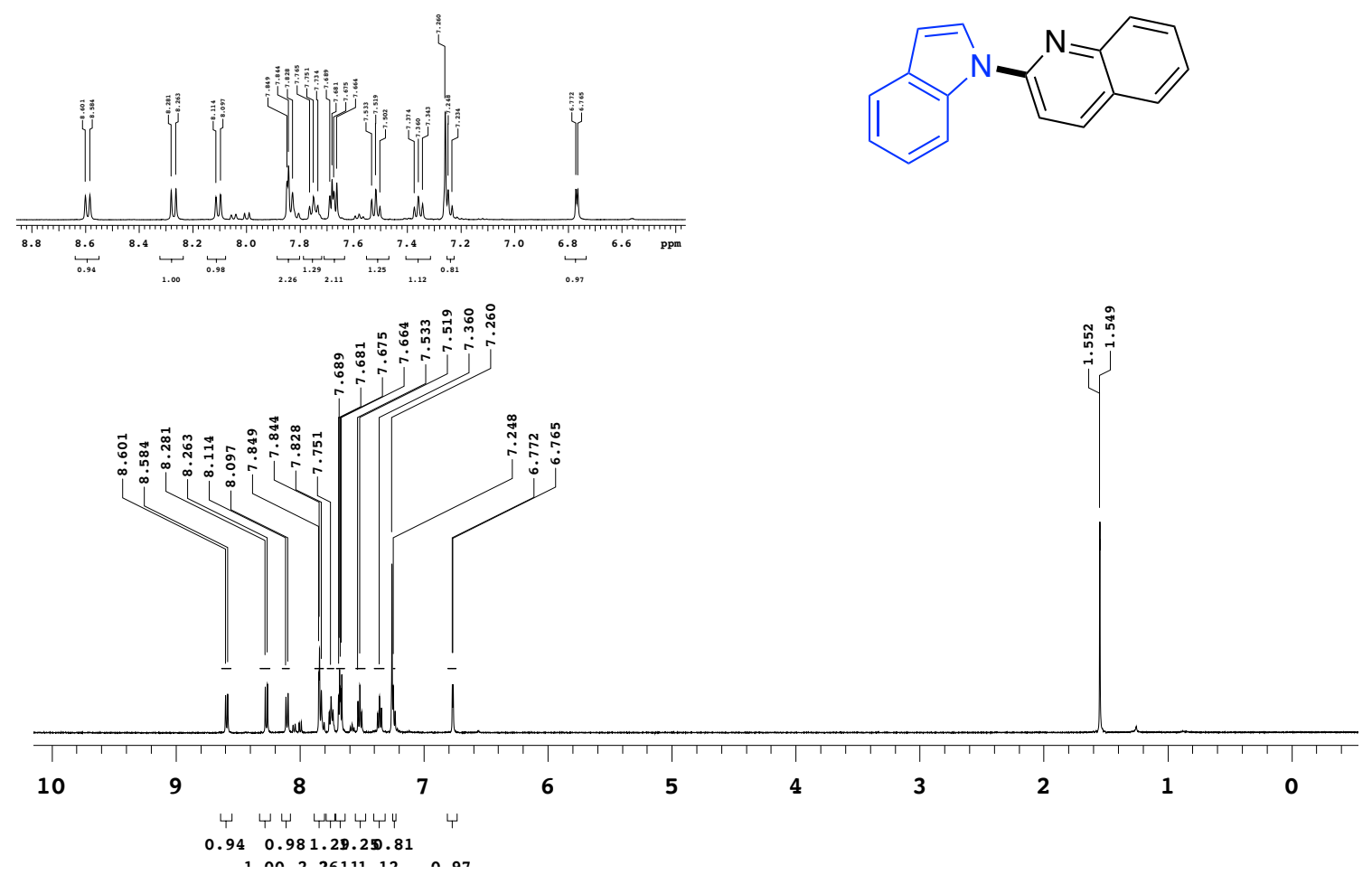

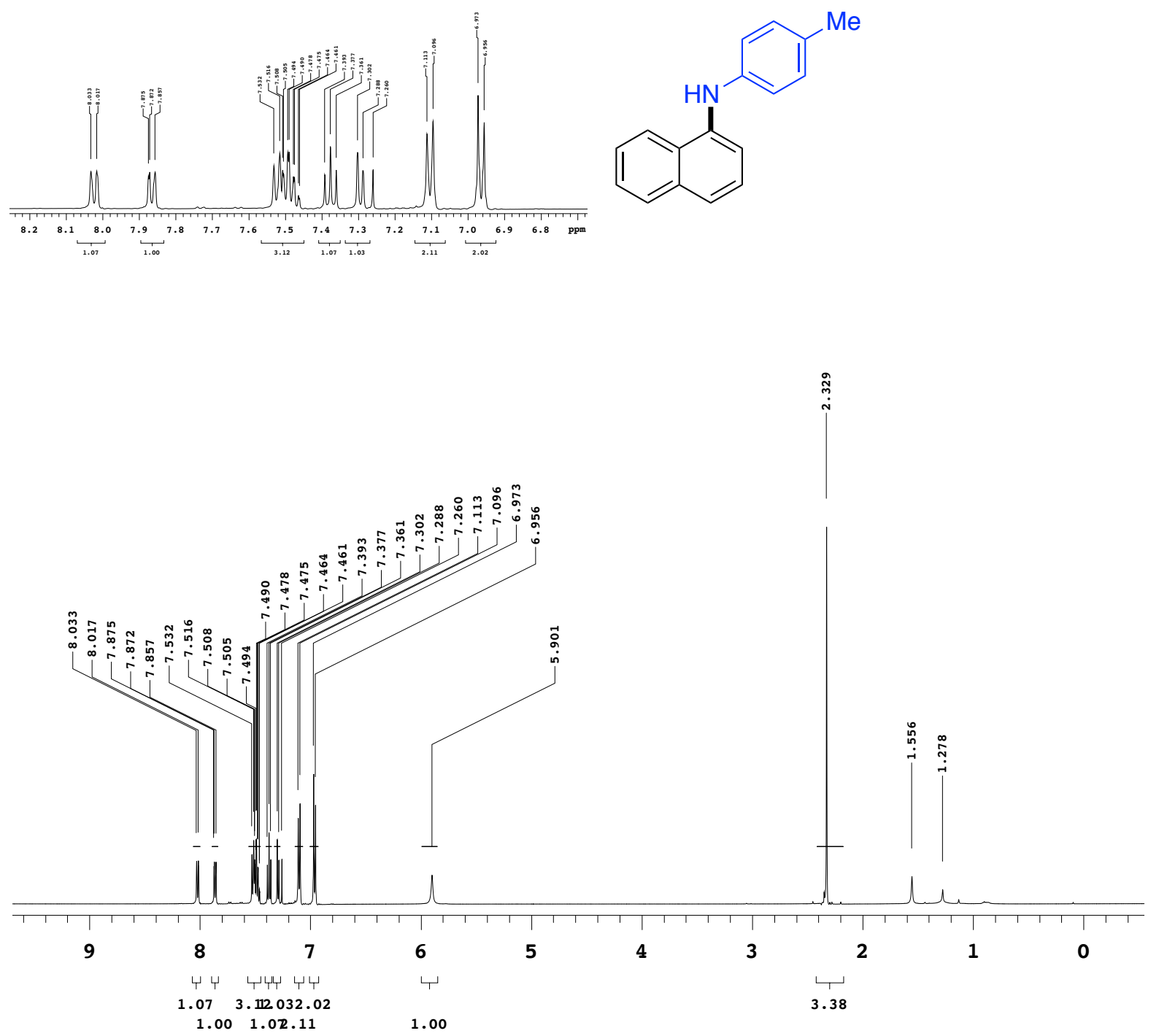

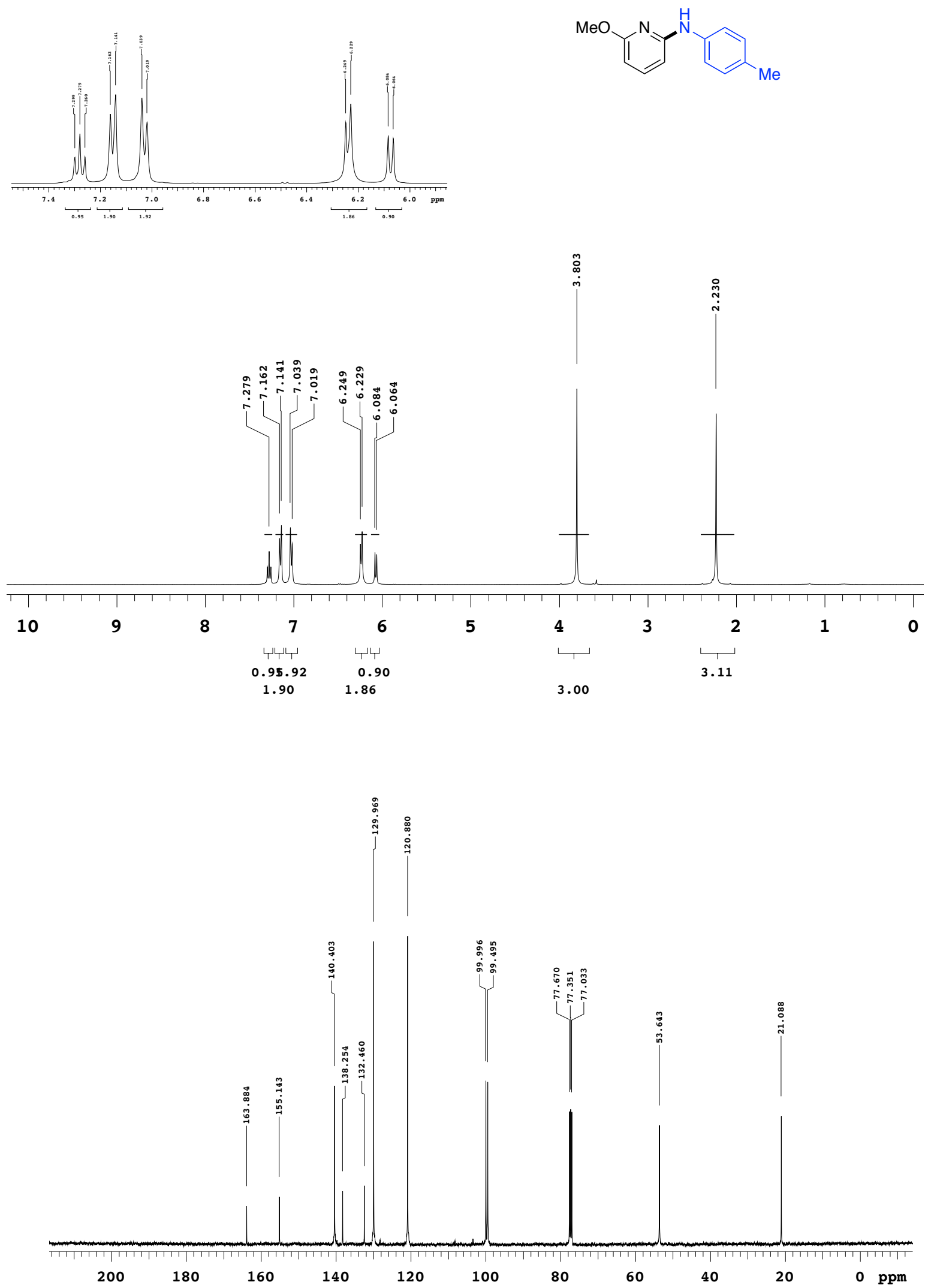

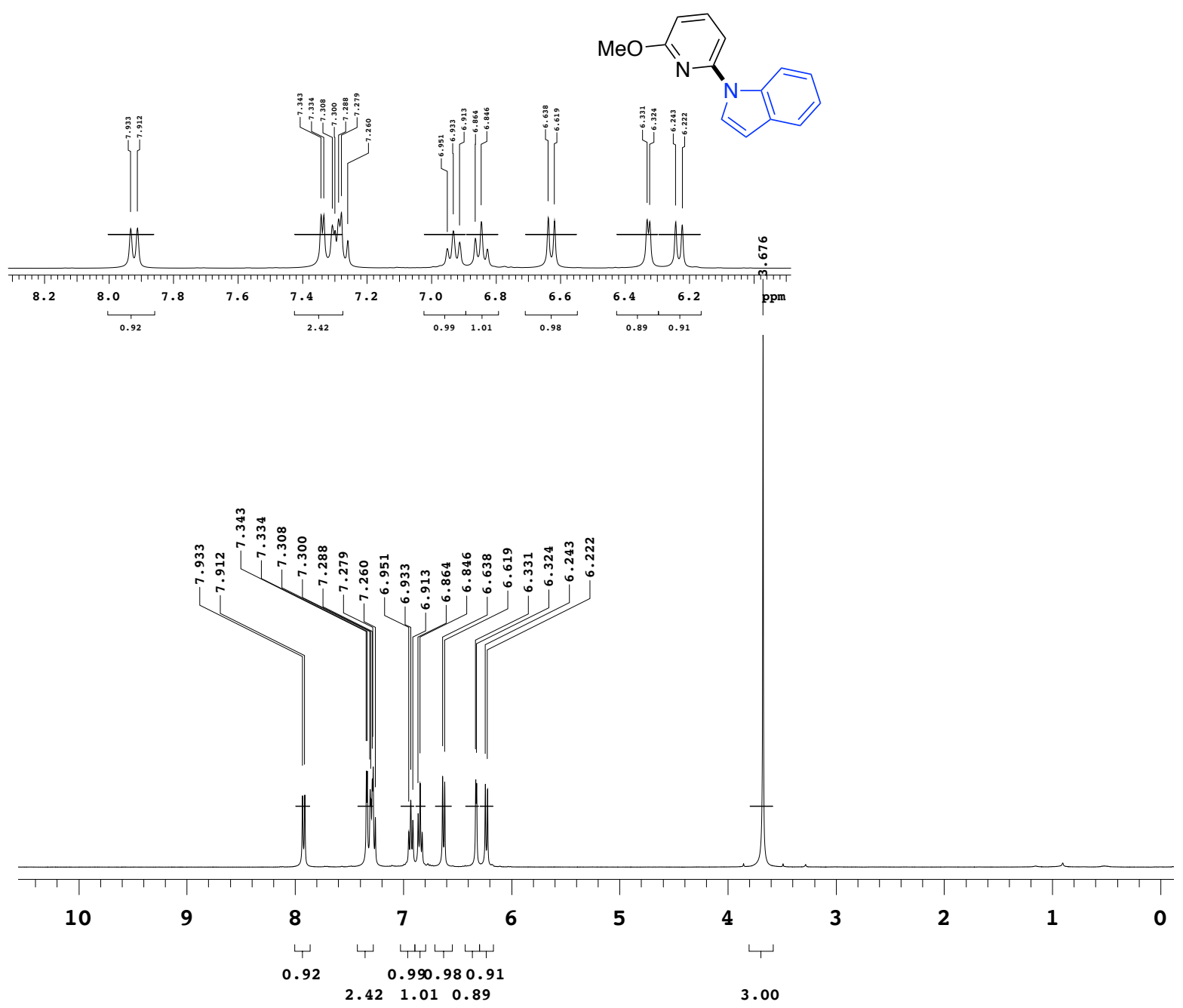

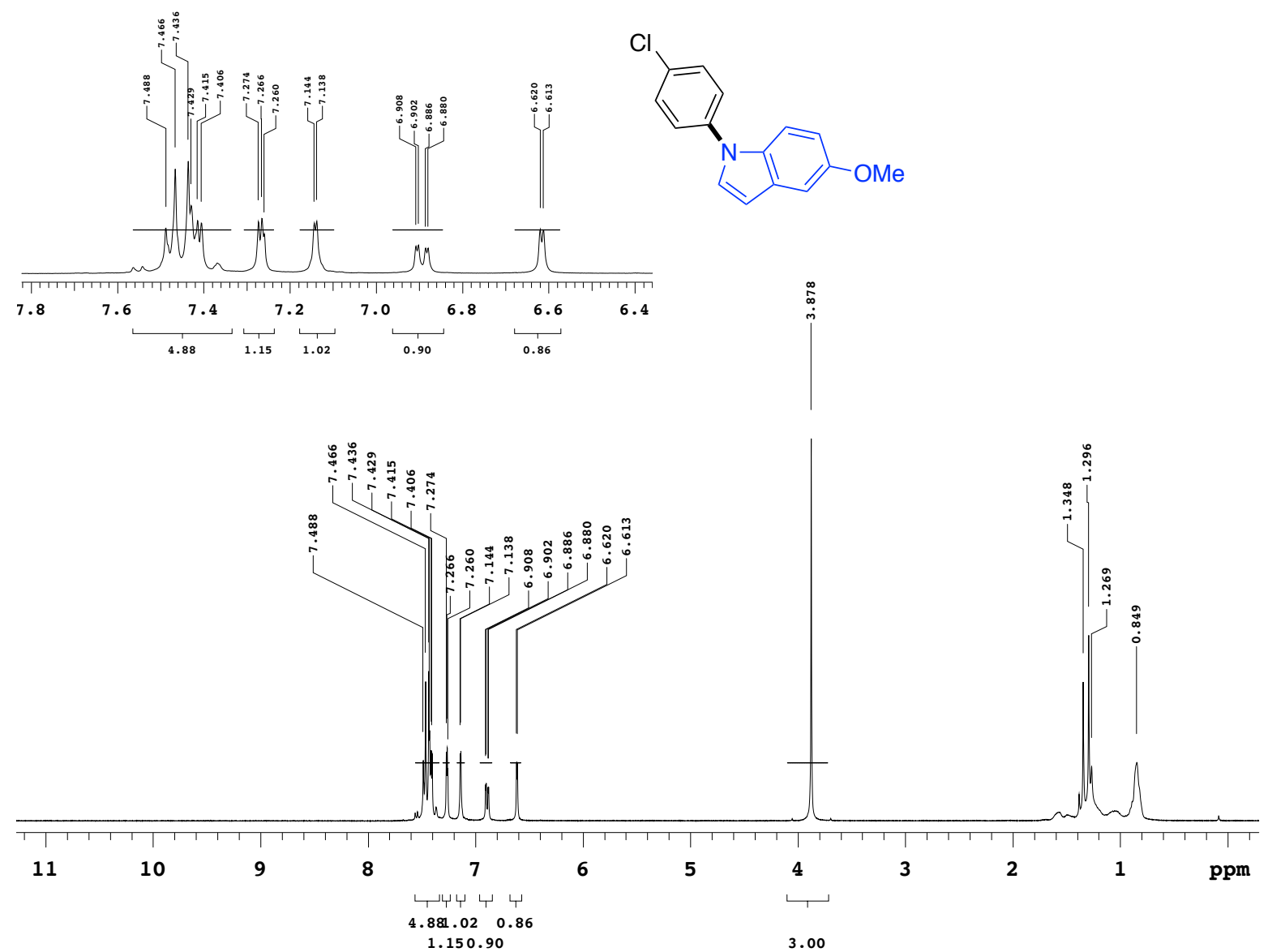


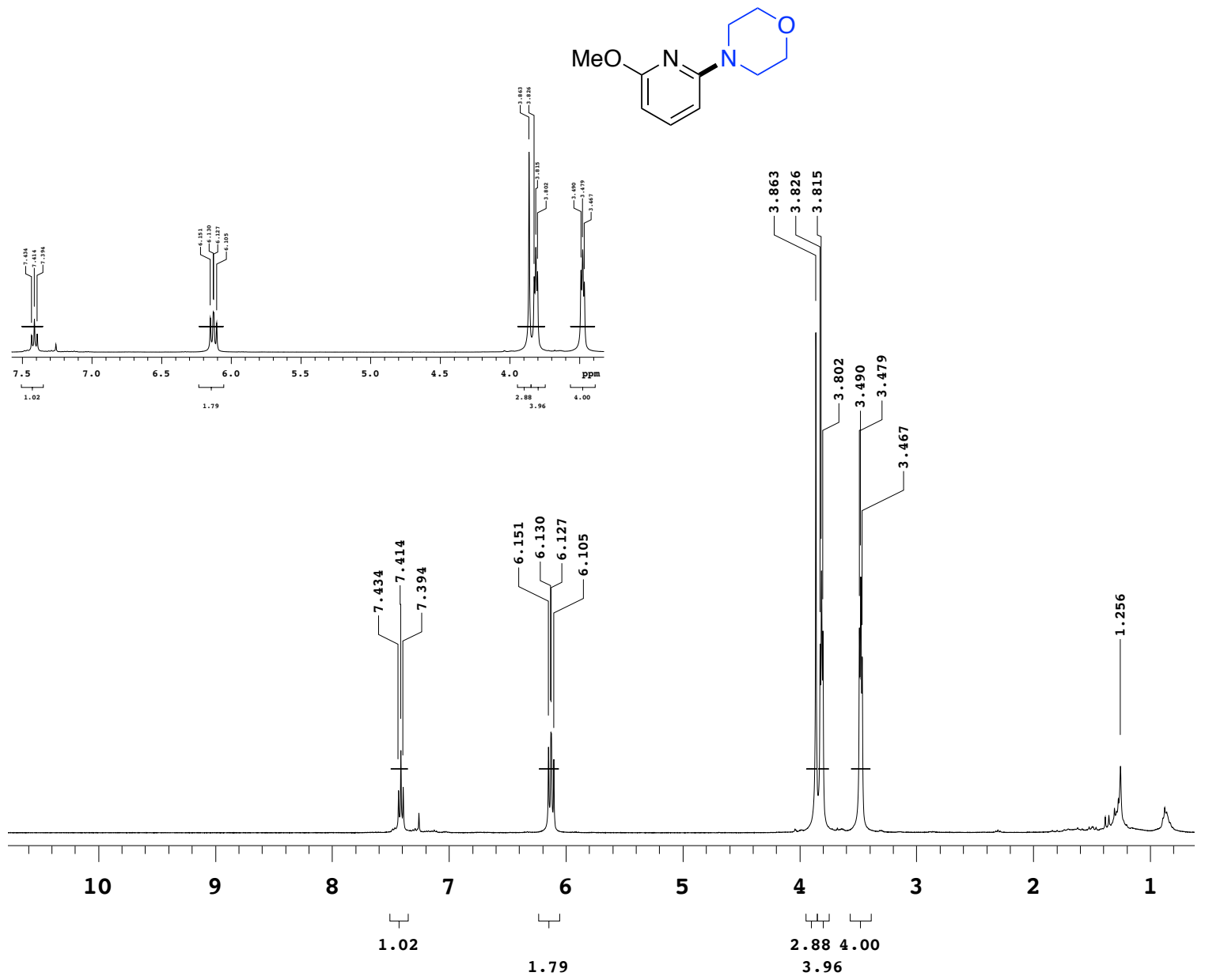




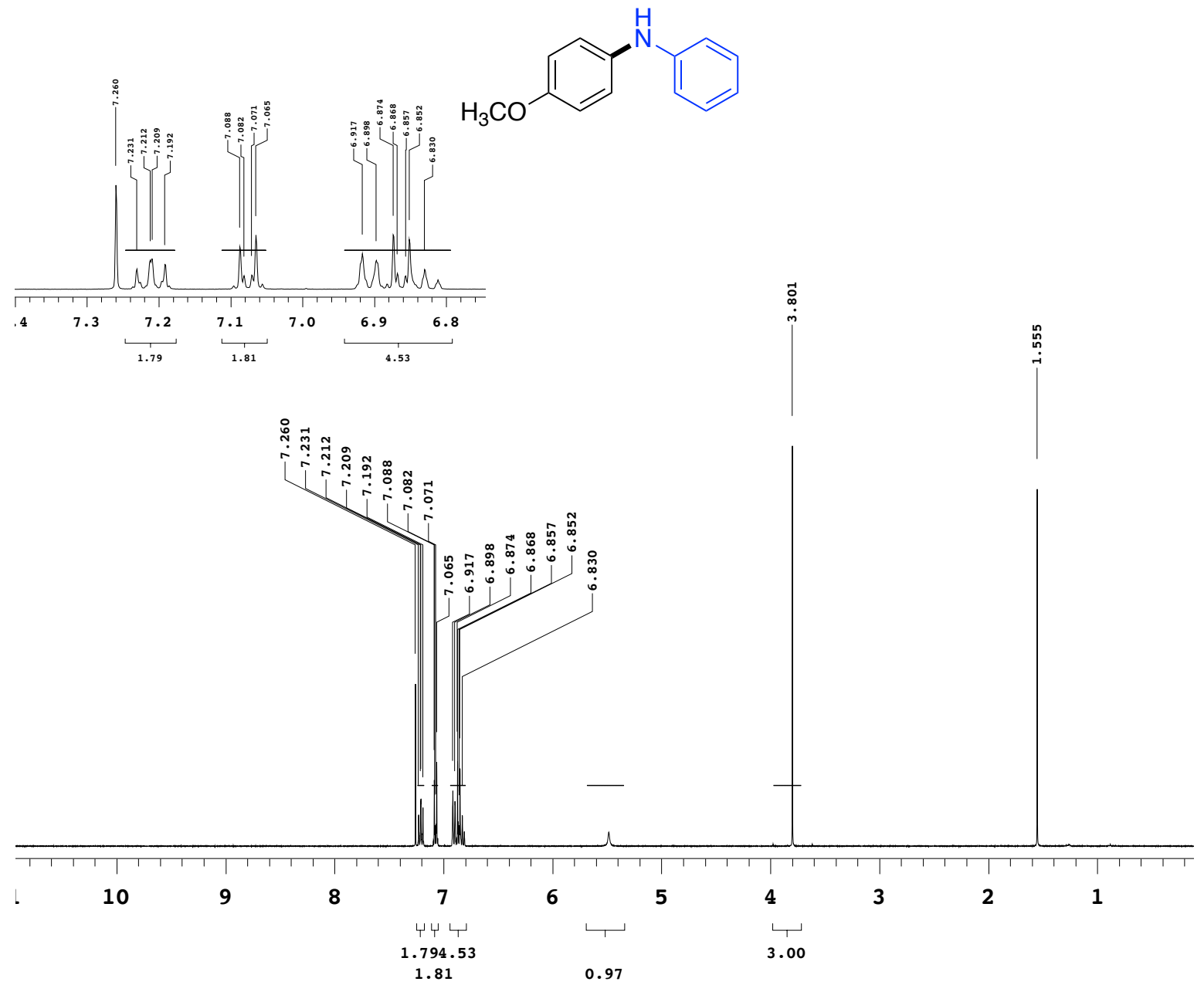



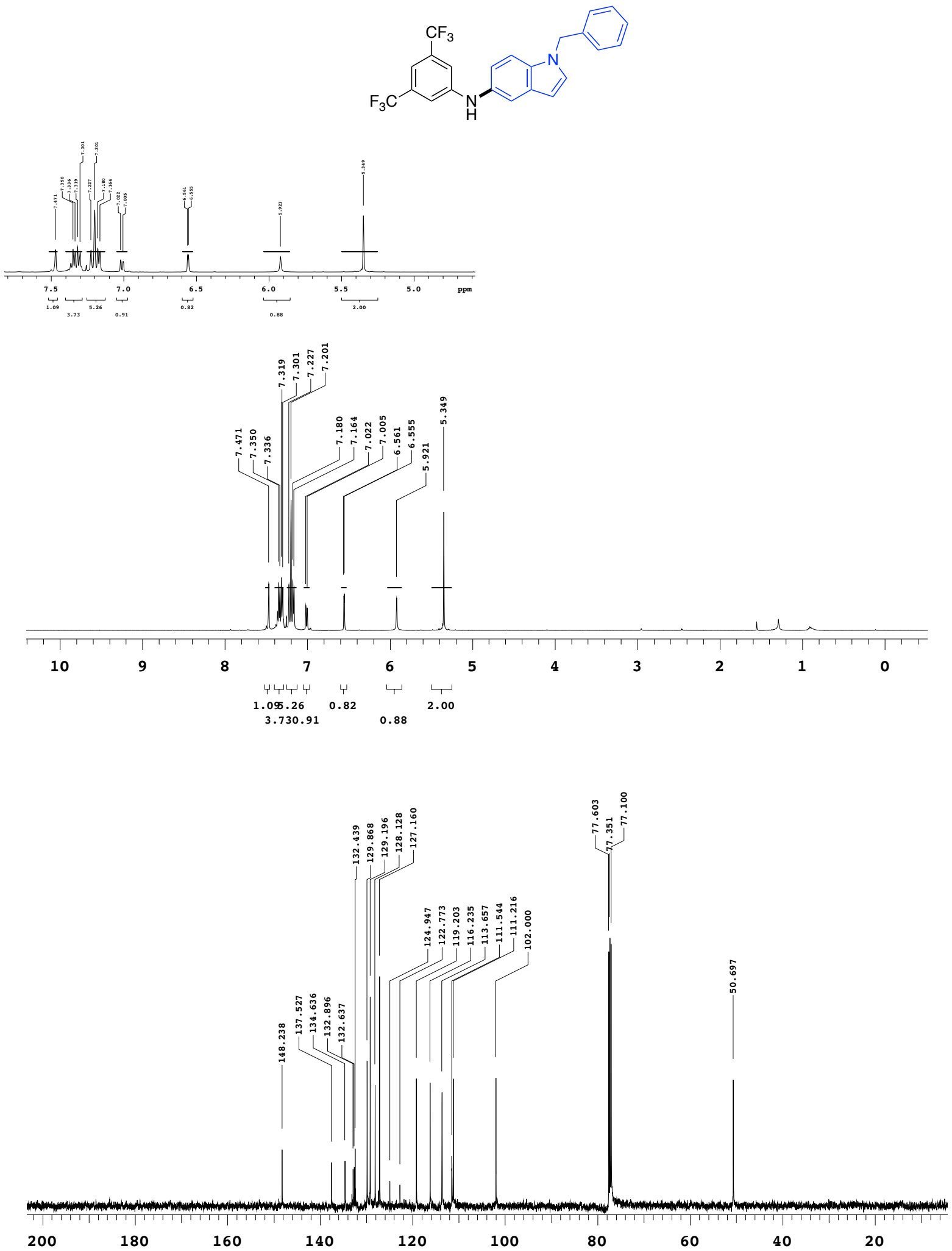


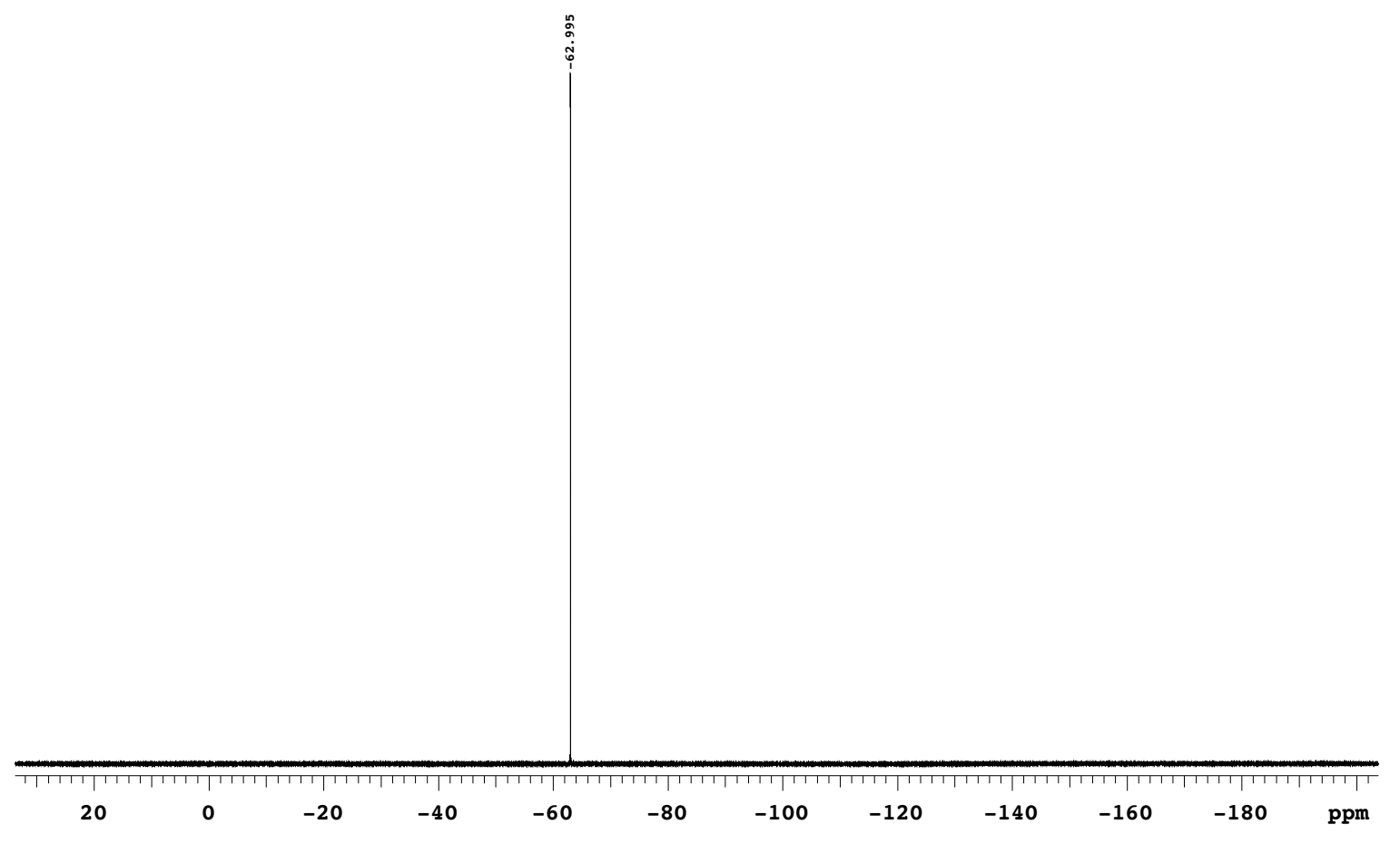




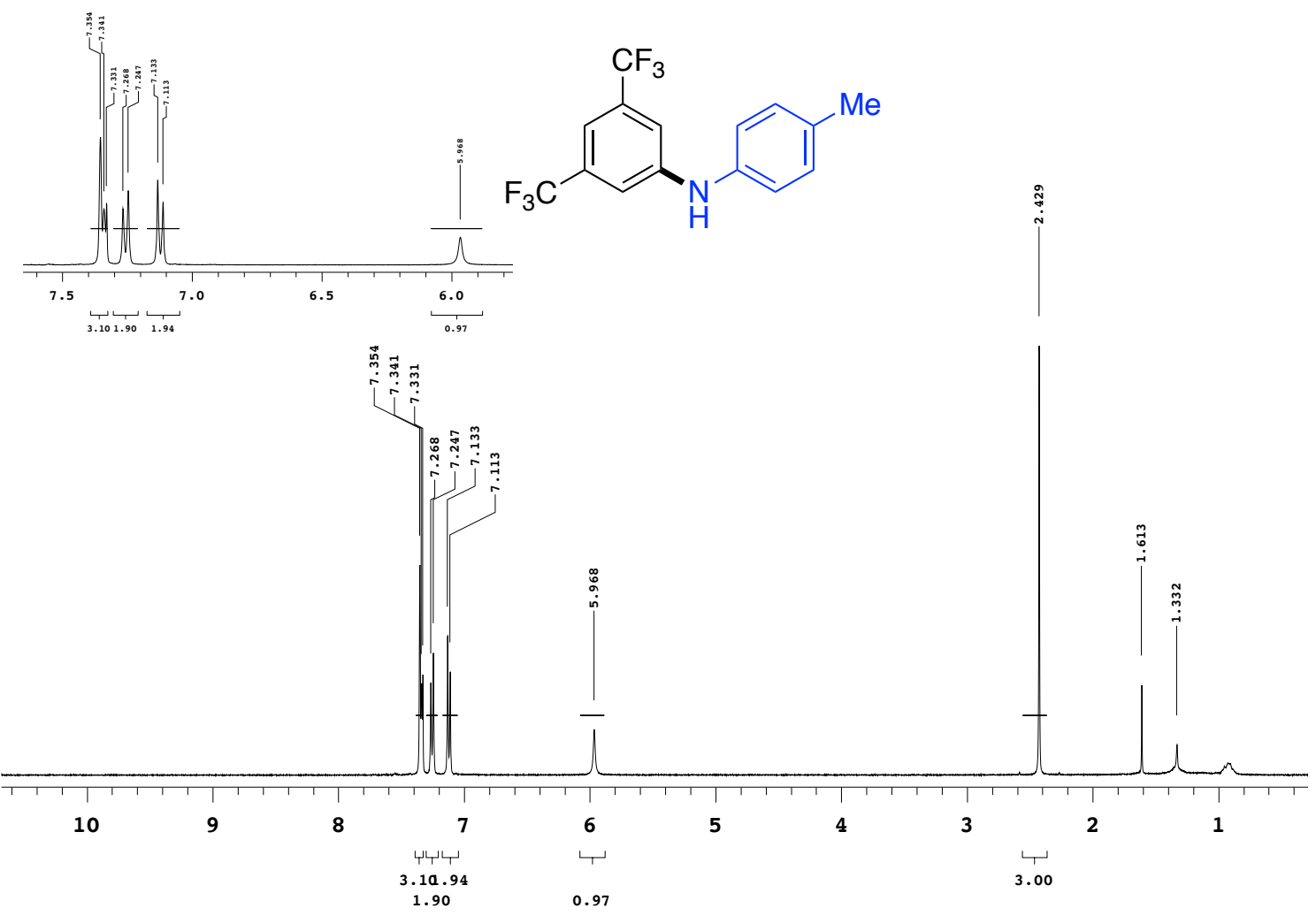



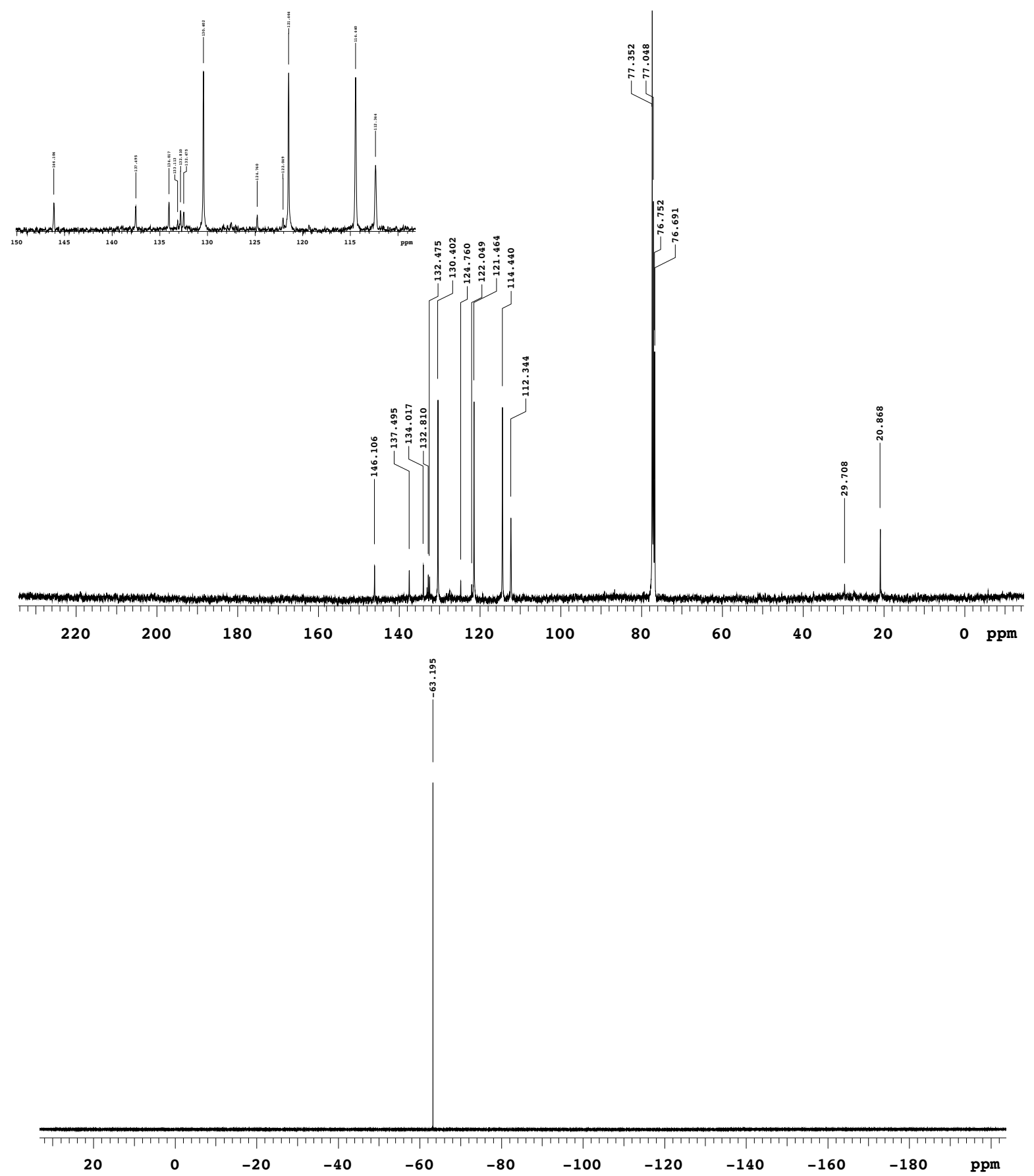

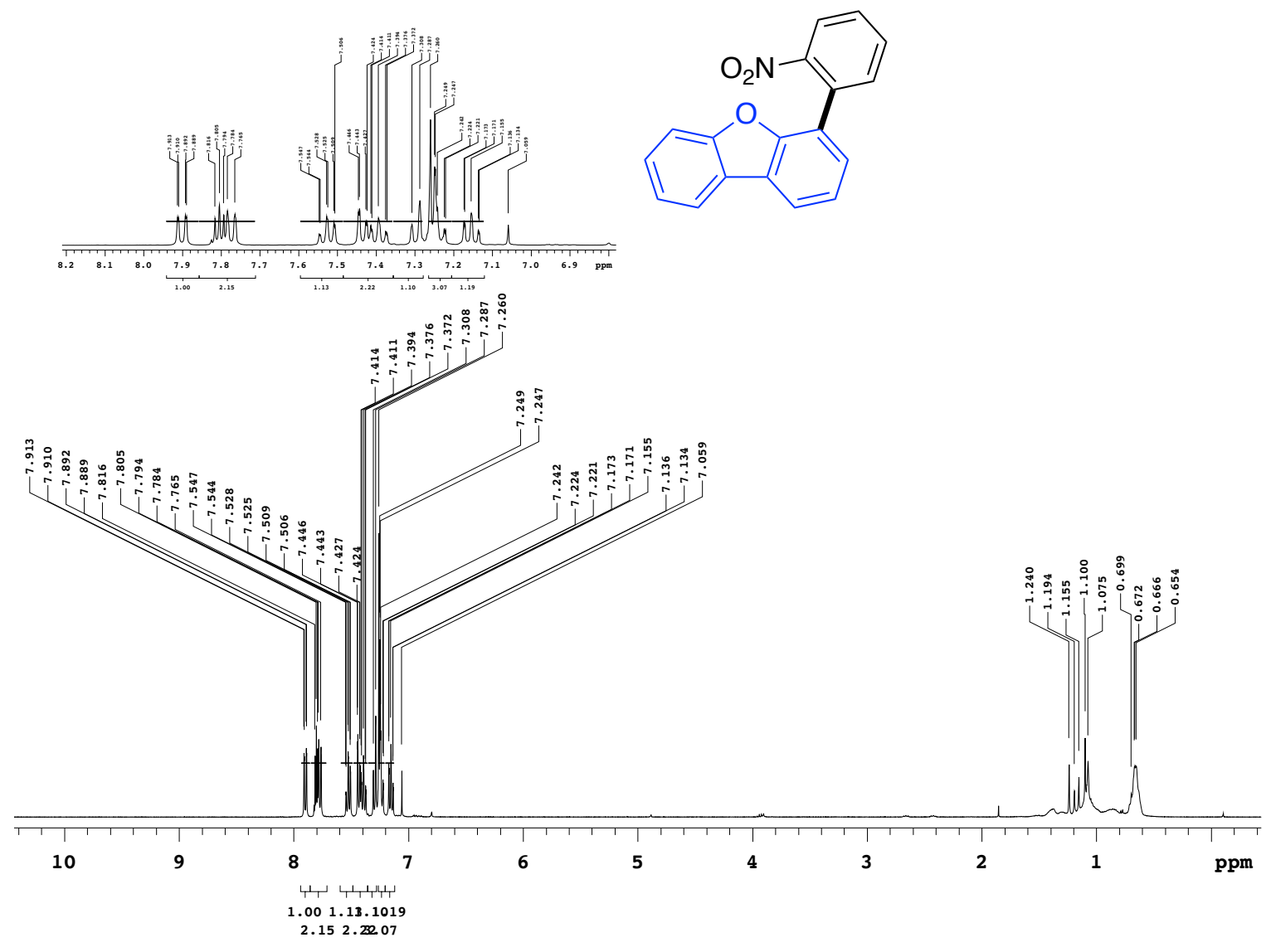


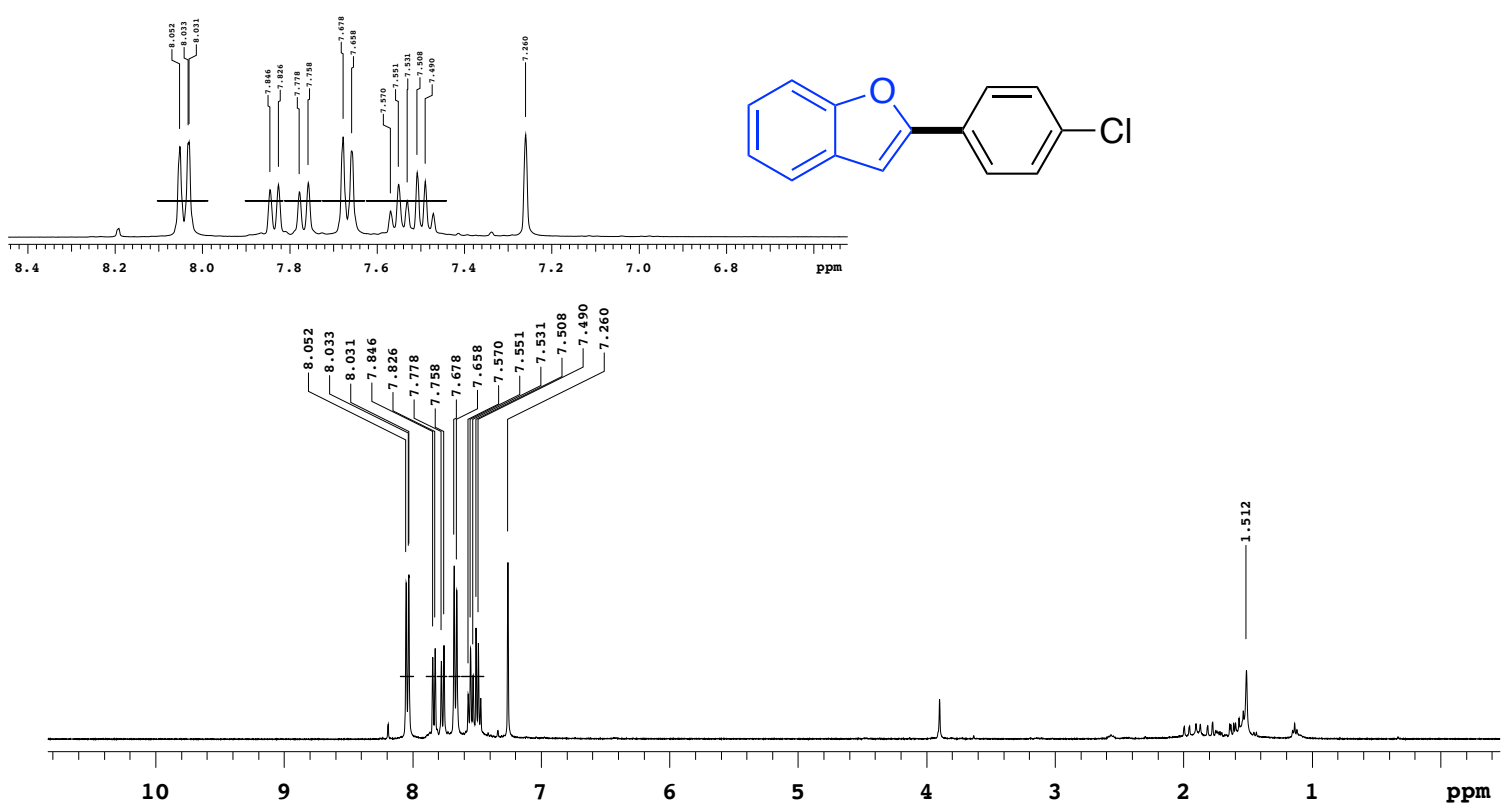



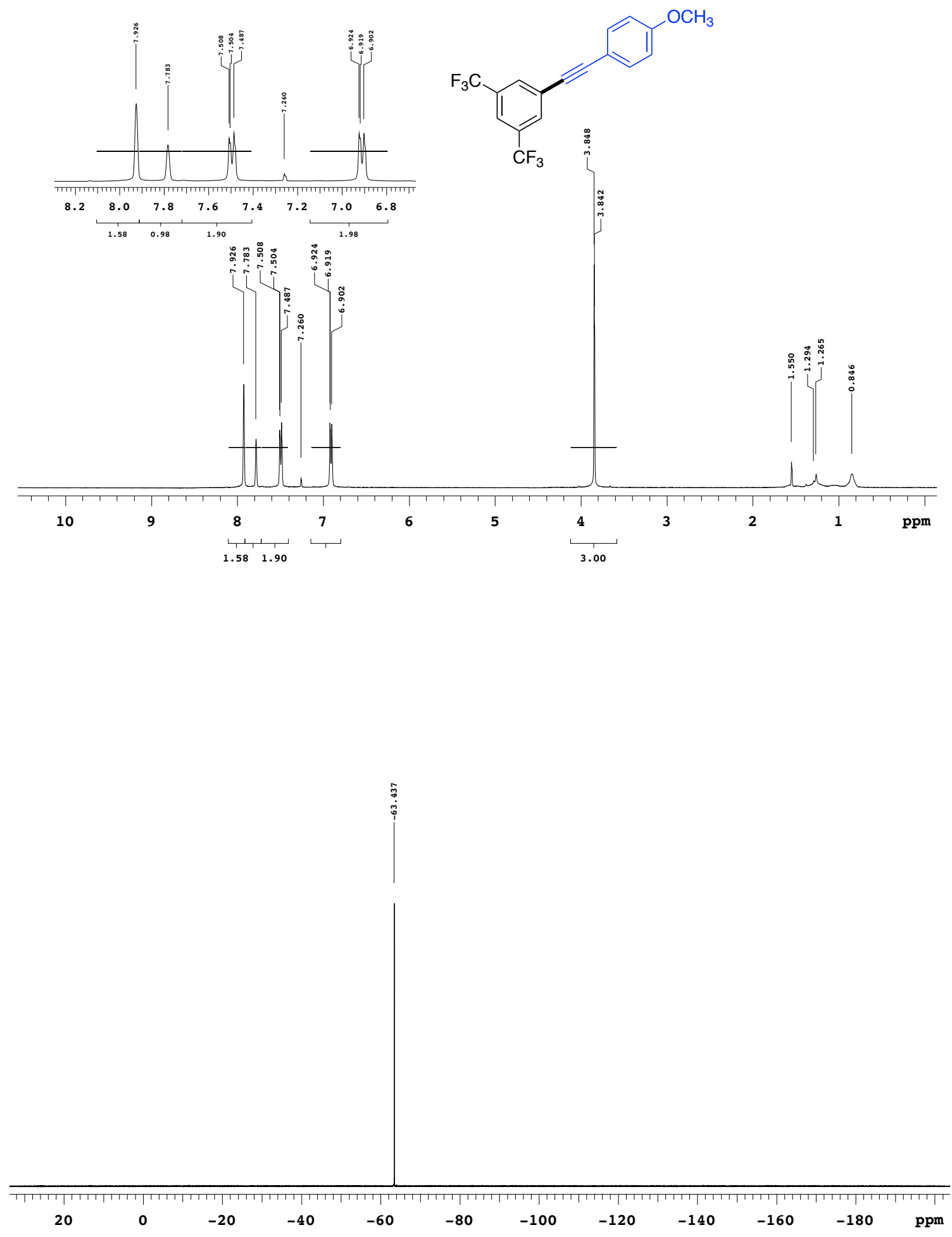


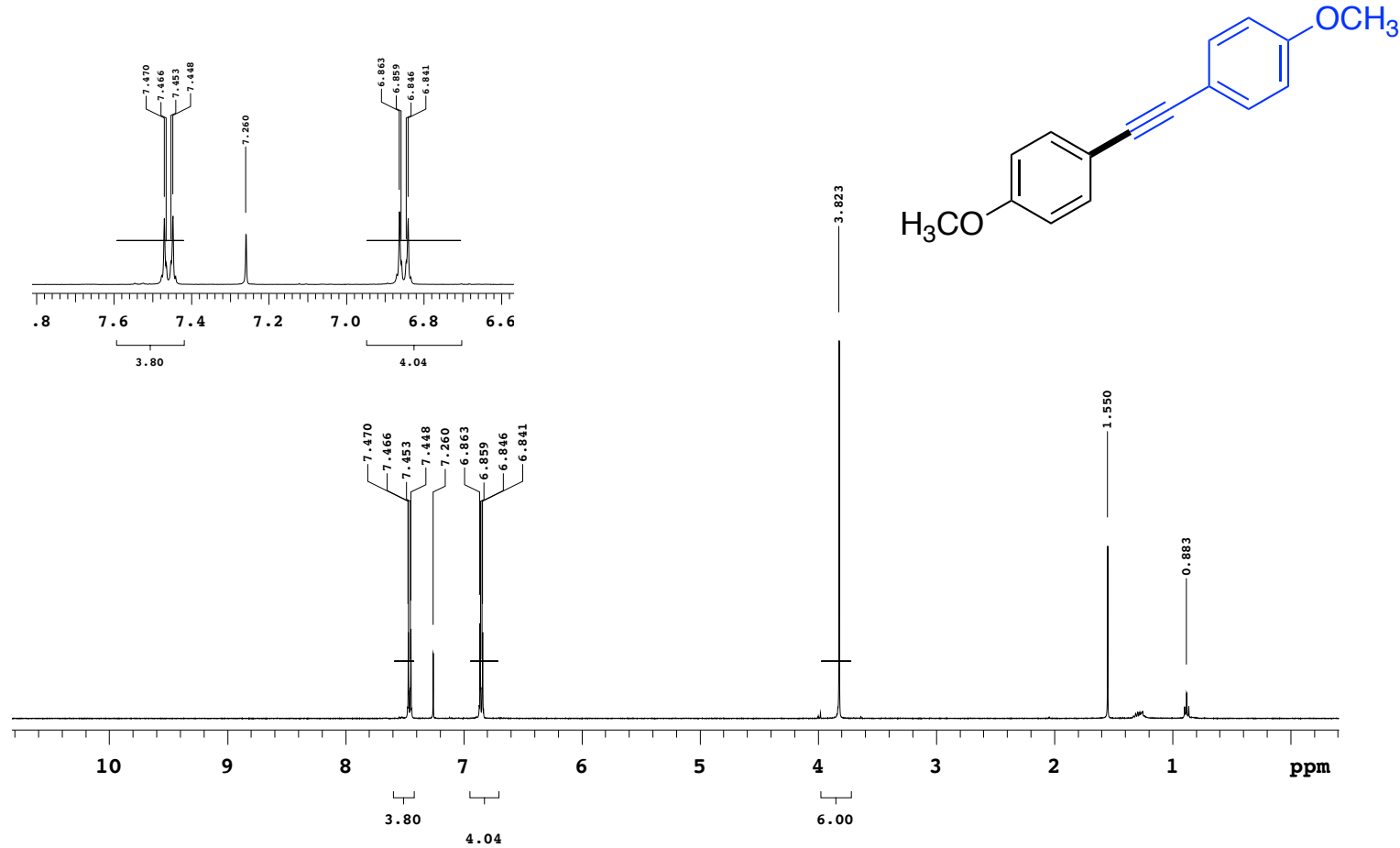



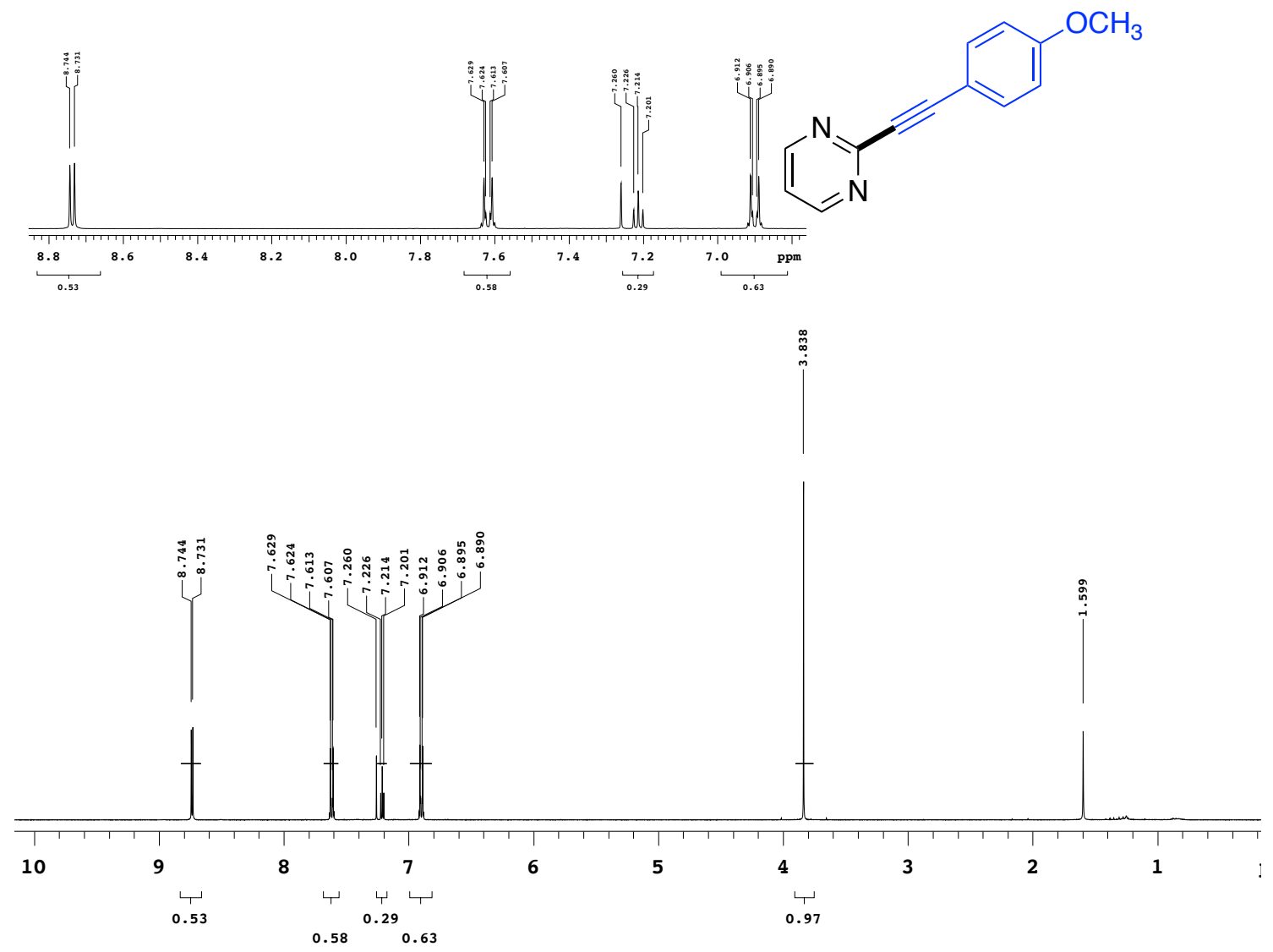